\title{
Clean Energy Partnerships: A Decade of Success
}

\author{
March 2000
}

\author{
U.S. Department of Energy
}

Office of Energy Efficiency and Renewable Energy

Washington, DC 20585

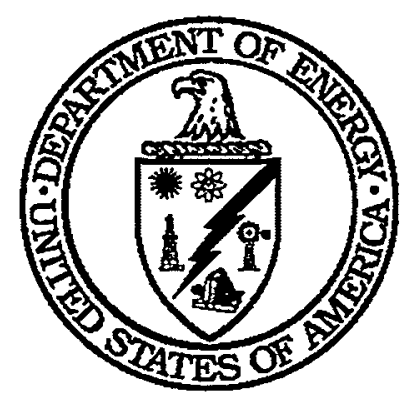




\section{DISCLAIMER}

This report was prepared as an account of work sponsored by an agency of the United States Government. Neither the United States Government nor any agency thereof, nor any of their employees, make any warranty, express or implied, or assumes any legal liability or responsibility for the accuracy, completeness, or usefulness of any information, apparatus, product, or process disclosed, or represents that its use would not infringe privately owned rights. Reference herein to any specific commercial product, process, or service by trade name, trademark, manufacturer, or otherwise does not necessarily constitute or imply its endorsement, recommendation, or favoring by the United States Government or any agency thereof. The views and opinions of authors expressed herein do not necessarily state or reflect those of the United States Government or any agency thereof. 


\section{DISCLAIMER}

Portions of this document may be illegible in electronic image products. Images are produced from the best available original document. 


\section{FOREWORD}

The Office of Energy Efficiency and Renewable Energy (EERE) manages a portfolio of research, technology development, demonstration, deployment, and project activities that supports the U.S. Department of Energy's strategic objectives. The results of these programs are dramatic - from a more efficient industrial base to a growing clean energy technology industry; from tremendous energy savings in homes, offices and government buildings to fleets of vehicles powered by domestically produced alternatives to imported petroleum fuels.

In this publication we have gathered some examples of recent accomplishments of EERE programs so stakeholders can see the value they are receiving from their investments. These are stories of positive impacts on real people and places that can be linked to DOE-sponsored activities, and have both quantitative and tangible benefits. While they do not comprise a comprehensive compendium of achievements, they do illustrate the range and diversity of successful EERE programs.

This report provides an analysis of program impacts giving credible evidence of positive returns on investment for a selection of accomplishments from the 1990s. This effort followed standard quality assurance techniques and included reviews by objective experts outside of DOE who are familiar both with EERE technologies and with evaluation techniques. These experts reviewed drafts of these success stories and also examined accompanying documentation.

I want to thank all of the EERE program managers and headquarters and regional staff who made these stories possible. Thanks are especially due to Eric Petersen and Darrell Beschen for initiating this effort. The passing of Eric in August 1999 was a terrible loss. He was a valued contributor to EERE's programs and a personal friend. He will be sorely missed. I would also like to recognize the contributions made by a multi-laboratory team comprised of Marilyn Brown and John Munro from Oak Ridge National Laboratory, Gretchen Jordan of Sandia National Laboratories, and John Mortensen of the National Renewable Energy Laboratory.

Finally, our success depends on the commitment and ingenuity of numerous DOE program managers and staff, National Laboratory scientists and engineers, and collaborators and partners in industry, nongovernmental agencies, universities, utilities, state and local governments, and other government agencies. I believe we can all be proud of and share in the credit for the success stories presented in this publication. I look forward to future successes on behalf of the nation.

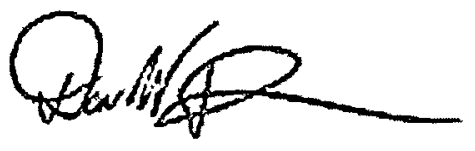

Dan W. Reicher

Assistant Secretary

Energy Efficiency and Renewable Energy 


\section{CONTENTS}

FOREWARD .ii

EXECUTIVE SUMMARY

INTRODUCTION AND OVERVIEW OF BENEFITS.

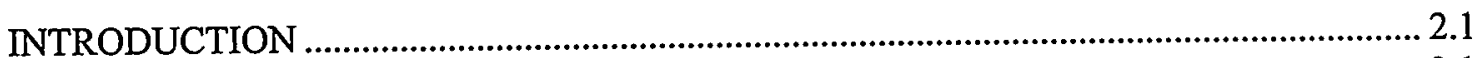

BACKGROUND

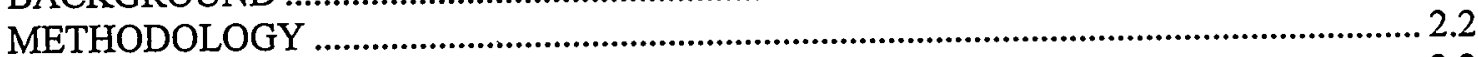

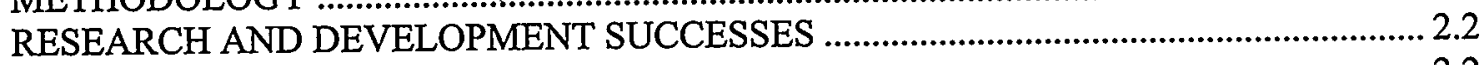

Some Recent Accomplishments ............................................................................... 2.2

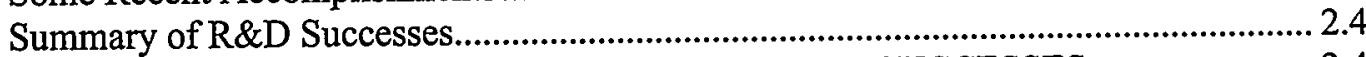

FIELD VERIFICATION, DEPLOYMENT, AND OUTREACH SUCCESSES ....................... 2.4

Some Recent Accomplishments ................................................................................. 2.5

Summary of Field Verification, Deployment, and Outreach Successes .......................... 2.5

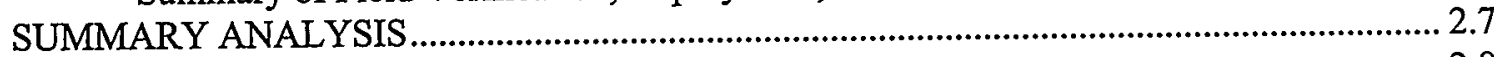

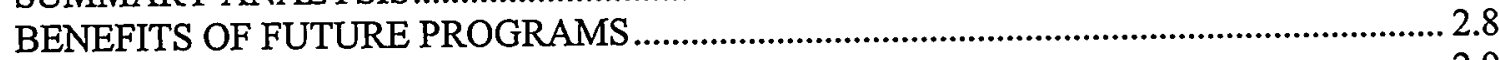

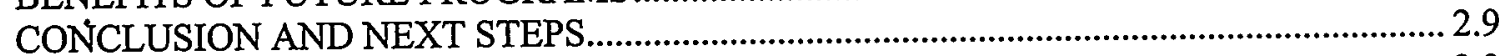

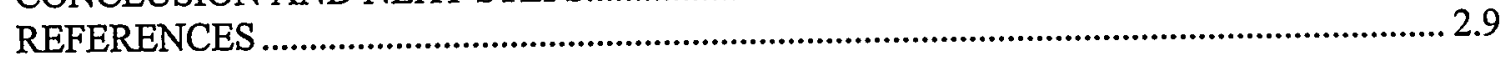

RESEARCH AND DEVELOPMENT SUCCESSES ....................................................... 3.1

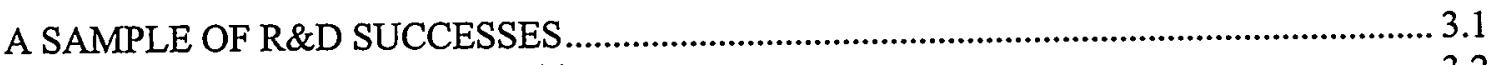

Compact Fluorescent Torchieres …............................................................................ 3.2

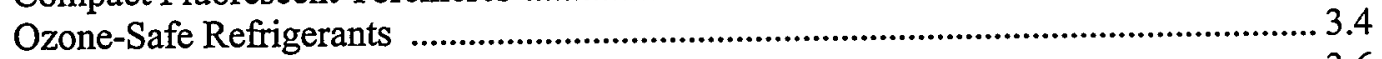

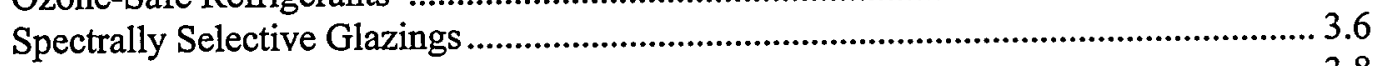

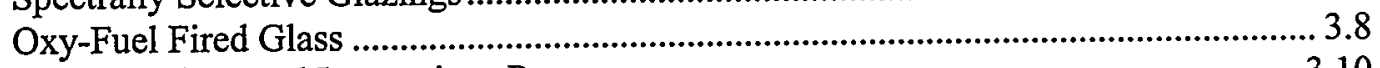

The Inventions and Innovations Program.................................................................... 3.10

Lightweight Materials for Automobile Structures ........................................................ 3.12

Cleaner and More Efficient Diesel Engines .............................................................. 3.14

Parabolic Troughs: Solar Power for Today .................................................................. 3.16

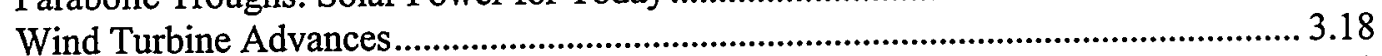

Geothermal Heat Pumps........................................................................................ 3.20

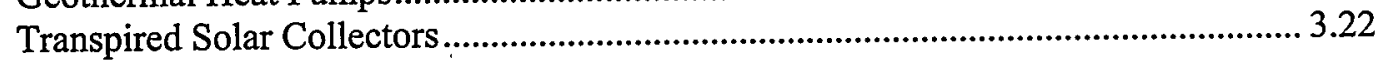

FIELD VERIFICATION, DEPLOYMENT, AND OUTREACH SUCCESSES ................ 4.1

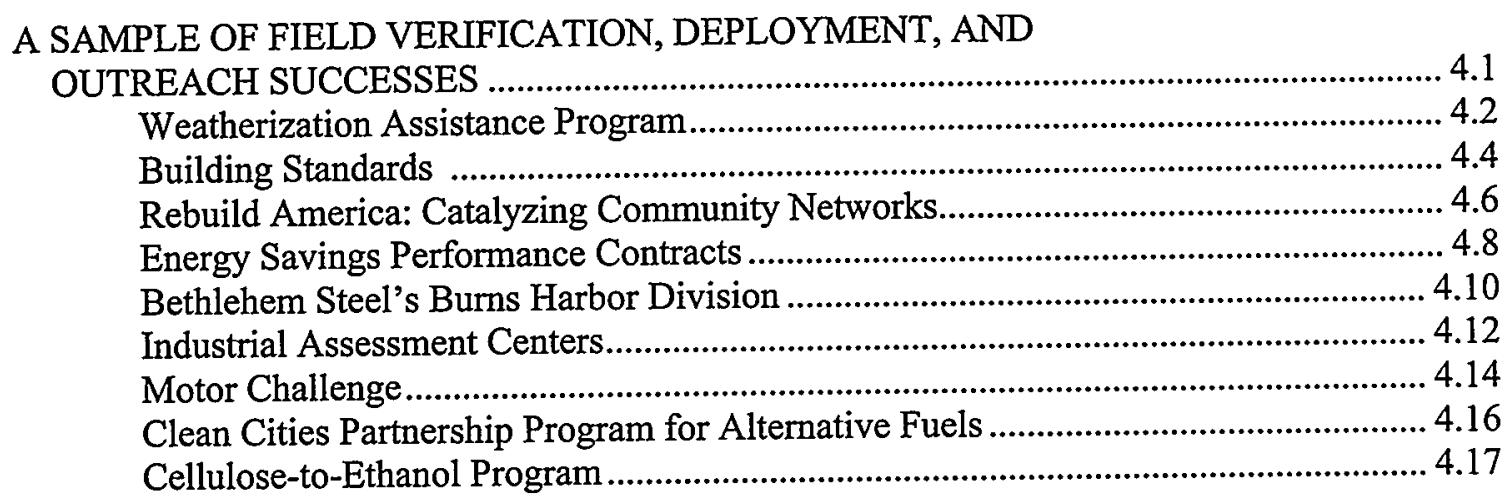


FEMP AND REGIONAL OFFICES HELP DEPLOY EXISTING TECHNOLOGIES.

The Forrestal Building Relighting Project

The Seattle Regional Office Community Initiative..................................................... 4.19

Energy Efficient Buildings in Wake of Flooding in North Dakota............................ 4.20

The Rebuilding of Valmeyer, Illinois.................................................................... 4.20

Hualipai Tribe Uses Photovoltaic Pumping System and Water Pipeline ..................... 4.21

Southwestern U.S. Postal Service moves to Alternative Fuel Vehicles....................... 4.21

Aquaculture Industry Develops in North Carolina................................................... 4.21

AFTERWORD — MORE SUCCESS IN THE PIPELINE ............................................... 5.1

SUMMARY OF PROJECTED BENEFITS FROM EMERGING R\&D SUCCESSES ............ 5.1

A SAMPLE OF EMERGING R\&D SUCCESSES................................................................ 5.2

Setting a Technology Benchmark for Refrigerator Efficiency..................................... 5.2

Combined Heat and Power (CHP) Systems .................................................................. 5.3

Lost-Foam Metal Casting Improves Quality, Reduces Energy Consumption ................. 5.3

Nickel Aluminide R\&D Increases Operational Efficiency ........................................... 5.5

Photovoltaic Thin Film Partnership Program.............................................................. 5.6

Biomass Gasifiers: Kindling Biopower Potential ..................................................... 5.7

High-Temperature Superconductivity ................................................................... 5.8

High-Efficiency, Low-Emissions Fuel Cell Technologies for Transportation ............... 5.8

Enhancing the Performance Characteristics of Batteries ............................................... 5.9

Solar Two: Clean Power on Demand................................................................. 5.10

Photovoltaic Manufacturing Improvements .......................................................... 5.11

A SAMPLE OF EMERGING FIELD VERIFICATION, DEPLOYMENT, AND

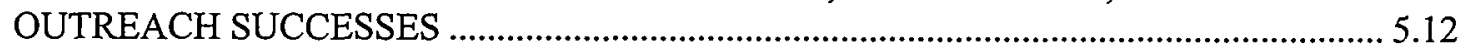

Building America: Innovation Through Systems Engineering ............................... 5.13

Greening Four Times Square............................................................................ 5.15

Federal Energy Management Program on Target to Meet Goals................................. 5.17

Renewable Energy Technologies in Federal Facilities .............................................. 5.19

FEMP Lamp Swap ....................................................................................... 5.21

FEMP Helps Government Agencies to Buy Energy Efficient Products ....................... 5.23

Federal Fleet Alternative Fuel Acquisition Program................................................ 5.25

Million Solar Roofs Initiative.................................................................................. 5.27

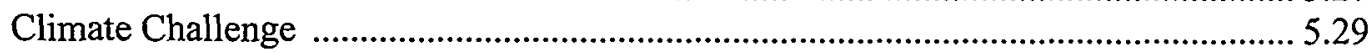

High Temperature Materials Laboratory ............................................................... 5.31

\section{APPENDICES}

APPENDIX A:

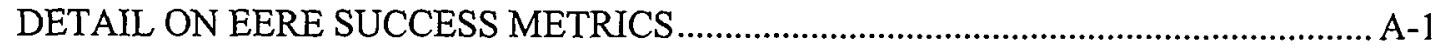

APPENDIX B:

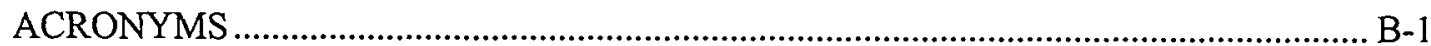

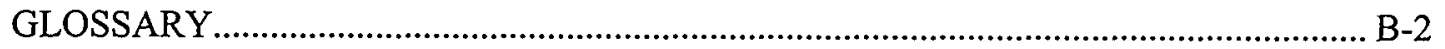




\section{EXECUTIVE SUMMARY}

This report contains a partial catalog of recent accomplishments of the U.S. Department of Energy's Office of Energy Efficiency and Renewable Energy (EERE) in collaboration with its many private- and public-sector partners. This compendium of success stories illustrates the range and diversity of EERE programs and achievements. Part of an ongoing effort, the principal goal of this collection is to provide stakeholders with the evidence they need to assess the value they are receiving from investments in these DOE programs. The report begins with an introduction and a description of the methodology. It then presents an overview of the accomplishments of EERE programs. This is followed by the stories themselves.

Twenty accomplishments are included in the summary analysis of quantified benefits for EEREsupported products and technologies installed to date. The metrics compiled for these successes are up-todate through Fiscal Year 1999. The approach to calculating benefits and costs is detailed in Appendix A.

EERE invested $\$ 712$ million in the projects described in the 20 stories. Additional costs have been incurred by the numerous industrial, university, utility, and public-sector collaborators that have also invested in the commercialization and deployment of these technologies.

More than 5,500 trillion Btu of energy has been saved from equipment implemented to date as a result of these 20 activities. Of this total, 5,050 trillion Btu of savings is from EERE R\&D successes, and almost 500 trillion Btu is from EERE field verification, deployment, and outreach successes. These savings are enough to meet the energy needs of all of the citizens, businesses, and industries located in the states of New York, Connecticut, and New Mexico, for one year. In addition, the 20 EERE R\&D and field verification, deployment, and outreach programs have replaced another 1,700 trillion Btu of fossil fuels with renewable alternatives. This is equivalent to running all of the cars registered in the states of California, Florida, Mississippi, and West Virginia on ethanol rather than gasoline, for one year. Significant reductions in carbon emissions from these 20 activities, 102 million metric tons, have resulted from these reductions in burning fossil fuels.

As an order of magnitude estimate, savings to the nation from these 20 activities are estimated to be $\$ 30$ billion (\$1998). This is based on the 5,500 trillion Btu of energy savings and the cost to consumers of an average Btu of energy consumed in 1998. In 1996, the General Accounting Office reviewed the success of five similarly situated technologies developed in the $1980 \mathrm{~s}$, and found a cumulative energy savings from all installations through 1996 to be $\$ 28$ billion, or over $\$ 3$ billion per year.

These benefits will continue to accumulate and grow as many of the technologies that have been commercialized with the support of EERE resources gain market share over the next several years. Compact fluorescent torchieres, spectrally selective glazings for windows, and lightweight materials for vehicles are examples of commercial products that are likely to produce much greater energy saving over the next decade than they have produced to date.

A sample of seven of the emerging technologies hold the promise of additional billions of dollars in energy savings, from a DOE R\&D investment in the 1990 s of $\$ 288$ million. $\$ 6$ billion could be saved annually if all refrigerators used as little power as DOE's recently-developed high-efficiency refrigerators. The use of nickel aluminides could save industry $\$ 180$ million, and another $\$ 160$ million in cost savings could come from the installation of combined heat and power systems. The application of high temperature superconductivity to reduce losses from the transmission and distribution of electricity could save more than $\$ 550$ million by 2010 . Lost foam metal casting, improvements to the manufacture of thin film photovoltaics, and the use of biomass gasifiers and other EERE accomplishments will also reduce energy costs in the future. 


\section{INTRODUCTION AND OVERVIEW OF BENEFITS}

\section{INTRODUCTION}

This report presents a number of stories of recent technology breakthroughs and program achievements of the U.S. Department of Energy's Office of Energy Efficiency and Renewable Energy (EERE). These documented accomplishments will allow stakeholders to assess the value they are receiving from investments in these DOE programs. This report is not a complete compendium of EERE's successes; resource limitations prevent an exhaustive cataloging of all of the positive outcomes of EERE's activities. However, this overview does illustrate the range and diversity of EERE programs and achievements.

The objective of this report is to measure, evaluate, and articulate EERE's successes at a corporate level based on quantitative benefits and costs, using methods that withstand critical review. The accomplishments documented here demonstrate that the activities of EERE's research and development (R\&D) and field verification, deployment, and outreach programs have resulted in significant energy savings, reduced energy costs, and decreased carbon emissions - key metrics by which EERE judges its success.

This document begins with an overview of the methodology used to select and document recent accomplishments. The remaining sections describe benefits and individual recent successes in two categories:

- $R \& D$ successes resulting in commercialized technologies that are successfully competing in the marketplace, and

- field verification, deployment, and outreach successes that have accelerated and expanded the use of existing efficient and renewable energy technologies.

An Afterword presents additional successes that document the numerous DOE-funded technologies in the pipeline for future commercialization, field verification, and deployment opportunities. Appendices A and $B$ provide detail on the calculations in the stories and a glossary for readers unfamiliar with the terms and abbreviations used in this report.

\section{BACKGROUND}

The EERE mission is to lead the nation in the research, development, and deployment of advanced energy efficiency and clean power technologies and practices, providing Americans with a stronger economy, healthier environment, and more secure future. EERE's mission is consistent ' with the federal government's role of investing in technologies and practices that are critical to the nation's strategic interests, but that do not receive adequate research and development investment from the private sector. EERE also works with stakeholders to develop policies and programs to facilitate the deployment of advanced clean energy technologies and practices.

This approach enables EERE programs to advance America's existing energy systems by:

- Helping ensure adequate, affordable supplies of clean energy,

- Reducing U.S. vulnerability to energy supply disruptions,

- Encouraging energy efficiency,

- Advancing renewable energy and natural gas technologies,

- Increasing energy choices for all consumers, and 
- Reducing the environmental impact of energy use.

EERE is committed to following best business practices, which involve effective performance measurement and refinement of program strategies as new information is obtained. This document is a product of that commitment to evaluation and continuous improvement.

\section{METHODOLOGY}

A careful selection process was used to arrive at an illustrative set of projects to be included in this publication. The first step was to generate a list of candidate accomplishments. These candidates were then mapped against the budget structure and program areas for EERE so an array of different programs would be included. The other criteria that guided the selection process were: significant breakthroughs or impacts since 1990; clear linkage between DOE expenditures and impacts; quantifiable, measured, and tangible benefits; documentation of DOE expenditures; and willingness by success story participants to provide additional data. Some of the data in the accomplishment stories are drawn from published sources. In other instances the multi-laboratory team ${ }^{1}$ collected and compiled data through discussions with DOE program managers, national laboratory staff, and others involved with the projects.

A summary analysis is based on 20 accomplishments (11 R\&D successes and nine field verification, deployment, and outreach successes), for which quantified benefits could be measured for products and technologies installed to date. Data on estimated future benefits for emerging R\&D successes were also collected.

The accomplishments detailed in this compilation were drawn from an array of different sources and describe a variety of program activities. The approach taken and the assumptions made in the calculation of benefits and costs differ across stories. Therefore, we have made no attempt to aggregate costs and benefits of the success stories.

As a means of external validation and quality control, the accomplishments and their supporting documentation were reviewed by experts from government, universities and the private sector who are familiar with the technologies and with program evaluation techniques. The assumptions in each success story were reviewed for conformity with accepted evaluation methodologies. Limited resources, however, did not permit extensive recalculations based on standardized assumptions.

\section{RESEARCH AND DEVELOPMENT SUCCESSES}

\section{Some Recent Accomplishments}

The following accomplishment stories describe new technologies that were spawned by EERE's R\&D programs and that are currently contributing to U.S. energy, environmental, and economic strategic interests (Box 1). These technologies increase the efficiency of energy use in buildings, industry, and transportation and advance the development of renewable energy resources. The R\&D teams range from individual inventors to industrial consortia, and often involve researchers and the facilities of DOE's National Laboratories. More detail on the level of DOE R\&D investment and the actual benefits from the $R \& D$ successes showcased in this report is available in Appendix A.

\footnotetext{
${ }^{1}$ The multi-laboratory team consisted of Oak Ridge National Laboratory, Sandia National Laboratories, and the
} National Renewable Energy Laboratory. 


\section{Box 1: Eleven R\&D Successes}

- Hazardous, energy-intensive halogen torchieres are being replaced by safe and efficient compact-fluorescent torchieres developed by Lawrence Berkeley National Laboratory in collaboration with lighting industry partners. Energy cost savings from the sale of the 200,000 compact fluorescent bulbs sold in 1998 will be $\$ 41$ million over the 7-year life of the bulbs.

- DOE's leadership and research in collaboration with industry, Oak Ridge National Laboratory, and the National Institute of Standards and Technology accelerated the development of ozonesafe refrigerants by an estimated two years and averted a $\$ 16$ billion energy penalty.

- Spectrally selective glazings developed by Lawrence Berkeley National Laboratory in collaboration with manufacturers and the National Fenestration Rating Council can cut cooling costs by $10-25 \%$ in hot climates. These cuts in cooling costs could result in savings of $\$ 1.3$ billion per year from lowered electricity bills by 2010 .

- Working with industrial partners the Office of Industrial Technologies funded R\&D on oxygenfueled glass furnace technologies, technologies used to manufacture 30 percent of all glass in 1999. Cumulative energy savings through 1997 totaled $\$ 28$ million, with over $\$ 7$ million in energy costs being saved annually by U.S. manufacturers.

- The Inventions and Innovations Program has provided small grants to more than 500 inventors; $25 \%$ of these grantees have produced commercialized technologies, and the sales of these products exceed $\$ 700$ million (\$1995) through 1996. Energy cost savings attributable to these grant-funded inventions were over $\$ 190$ million.

- DOE's efforts to develop lightweight materials for manufacturing auto parts have saved more than 6 billion gallons of motor fuel and reduced carbon emissions by approximately 15 million metric tons through 1997. The dollars saved in oil-based fuels over the period from 1978 to 1997 is estimated at about $\$ 7$ billion.

- DOE, in cooperation with industry partners, has developed diesel engine technologies that are both cleaner and more energy 'efficient, saving approximately 16 billion gallons of motor fuel and reducing carbon emissions by about 38 million metric tons through 1997 . The cumulative economic value of increased efficiency is estimated at about $\$ 17$ billion.

- Improvements in parabolic trough technology have reduced the O\&M costs of parabolic trough plants by $30 \%$, saving $\$ 4$ million per year and $\$ 42$ million over the lifetime of the trough. These improvements have also increased the performance of the world's largest solar plant to record levels.

- DOE's research partnerships with U.S. industry have led to wind turbine advances that are helping the United States be a leader in technology for the world's fastest growing energy source. Over their lifetimes turbines produced and installed by just one U.S. company will displace 110 trillion Btu of primary energy, save $\$ 246$ million in energy costs, and reduce carbon emissions by 2.1 million metric tons.

- Advances in geothermal heat pumps have substantially reduced the heating and cooling loads of hundreds of thousands of residential, commercial, and institutional buildings across the United States. Over their lifetimes, the pumps installed between 1995 and 1998 are estimated to save $\$ 980$ million in energy costs and reduce carbon emissions by 1.7 million metric tons.

- The development of 80 percent efficient transpired solar collectors have provided commercial and industrial facilities with a cost-effective means for preheating ventilation air. Over their lifetimes the 52 systems installed as of 1999 will save $\$ 10$ million in avoided fuel costs. 


\section{Surnmary of R\&D Successes}

These 11 R\&D successes have received approximately $\$ 230$ million of support from DOE. The Inventions and Innovations Program, with a cumulative budget of $\$ 84$ million, received the largest share of this funding, with other programs receiving funding ranging from $\$ 1$ million to $\$ 45$ million in DOE appropriations.

Additional investments have been made by the companies that manufacture and distribute these technologies. Typically, these companies were partners early in the R\&D effort, thereby enriching the research program with the industry's knowledge of the manufacturing and marketing features required for success. For most of these projects, DOE funding came entirely through EERE; the vast majority of this funding was appropriated in the $1990 \mathrm{~s}$.

These $11 \mathrm{R} \& \mathrm{D}$ successes have enabled the nation to save 5,050 trillion Btu of energy. Included in this figure is a 2,000 trillion Btu energy penalty averted because a DOE partnership accelerated the development of ozone-safe refrigerants by one to two years, resulting in an estimated $\$ 16$ billion in savings. Diesel engine technologies developed by DOE, in cooperation with industry partners, are both cleaner and more energy efficient, saving approximately 2,180 trillion Btu, equivalent to 16 billion gallons of motor fuel, and reducing carbon emissions by about 40 million metric tons through 1997. An additional 112 trillion Btu of fossil energy has been replaced by DOE partnerships in wind turbine technology and transpired solar collectors, two of the renewable-energy R\&D successes described in Box 1. Additional energy will be saved as the technologies that are currently installed continue to generate benefits, and as new equipment is put into use.

Some of the commercialized technologies (such as lightweight materials for automobile use and ozonesafe refrigerants) have captured significant market share. However, most of the commercialized technologies are still in the initial stages of market penetration. If they do in fact reach full deployment, they promise to deliver enormous benefits. For instance, if one million compact fluorescent torchieres were bought instead of halogen torchieres, $\$ 27$ million in electricity costs would be saved each year and nearly $\$ 200$ million would be saved over the average seven-year operation of the lamps. The lives saved from the avoided fire hazard of halogen torchieres would add significantly to the ultimate roll-up of benefits.

Significant reductions in carbon emissions can also be seen. Roughly 90 million metric tons of carbon emissions have been avoided due to the commercial success of these 11 EERE-developed and supported technologies, along with some significant reductions in the emission of nitrogen dioxide and particulate matter. Additional benefits have resulted from these recent commercial successes, including O\&M cost savings, ozone protection, enhanced economic competitiveness, and greater energy security.

\section{FIELD VERIFICATION, DEPLOYMENT, AND OUTREACH}

EERE has developed strong partnerships with other government entities and the private sector to better leverage the federal investment in R\&D and to facilitate the deployment of new technologies. These partnerships often involve other parts of DOE (the Offices of Fossil Energy, Nuclear Energy, and Science) and other federal agencies. EERE also works closely with its National Laboratories, businesses, state and local governments, universities, nonprofit organizations, international partners, and Congress to disseminate information and facilitate the deployment of technologies by the private sector, including working with the private sector to set research and development priorities. 
Some of the technologies that these programs seek to deploy have been developed through EERE research and development programs. The Weatherization Program provides an example of this linkage. The retrofit measures used to improve the thermal integrity of homes occupied by low-income families include oil heaters with flame retention burners (a technology developed with EERE support), and the analysis software used to select retrofit measures for specific homes in the Weatherization Program is a product of EERE funding.

\section{Some Recent Accomplishments}

The nine field verification, deployment, and outreach accomplishments summarized below describe EERE programs that have a focus on the validation and deployment of existing technologies (Box 2). More detail on the level of DOE R\&D investment and the actual benefits from these successes is available in Appendix A.

\section{Summary of Field Verification, Deployment, and Outreach Successes .}

The investment of federal funds that generated the energy and cost savings benefits discussed in the accomplishments of these nine EERE deployment stories is about $\$ 480$ million. More than half of this is cumulative investments in the Building Standards and Guidelines Program and the National Biomass Ethanol Program. Another $\$ 125$ million is the 1998 budget for DOE's Weatherization Assistance Program. Utilities, companies and other partners involved in these programs have also contributed their expertise, time, and money to ensure the success of these programs.

The energy saved or replaced over the lifetime of technologies installed to date is 2,080 trillion Btu. Taken together, the ethanol fuels and Clean Cities programs have replaced about 1,580 trillion Btu of gasoline with ethanol. The energy savings include 108 trillion Btu accruing from the weatherization of low-income homes and 154 trillion Btu from the adoption of buildings efficiency standards. The total also includes 71 trillion Btu from recommendations in energy audits performed by some 30 Industrial Assessment Centers and 131 trillion Btu from 13 Motor Challenge Showcase Demonstration projects.

The value of the energy saved and the fossil energy replaced to date from these nine field verification, deployment, and outreach successes is considerable. Approximately $\$ 12$ billion in oil-based fuels have been replaced as a result of the Ethanol Fuel Program, and almost $\$ 1$ billion more has been replaced as a result of the Clean Cities programs, through 1998 . $\$ 1.1$ billion of the total has been saved to date due to building energy codes and standards and $\$ 300$ million is cost savings from DOE-funded energy audits for small and medium-sized manufacturers. Further, $\$ 162$ million in energy cost savings have resulted in 1999 from the retrofits that have resulted from Rebuild America partnerships, and \$550 million in energy expenditures will be saved as the result of building retrofits enabled by DOE's Weatherization program. Additional benefits could result from the Federal Energy Management Program's Energy Savings Performance Contracts. If the full contract authority for the contracts put in place by 2000 is used, $\$ 10$ billion of additional energy savings will result.

These nine field verification, deployment, and outreach programs will result in 13 million metric tons of carbon reductions. In addition to avoided carbon emissions, there have been, and will continue to be, reductions in nitrogen dioxide emissions and other harmful pollutants. Many other benefits have resulted from these nine programs, including thousands of jobs created, community development, and increased health and safety. 
Box 2: Nine Field Verification, Deployment, and Outreach Successes

- DOE and its partner agencies retrofit 167,000 homes in 1998 under the Weatherization Program, which will save 108 trillion Btu and save occupants $\$ 550$ million in utility bills over the 20-year life of installed energy-conservation measures.

- DOE has successfully used building energy codes and standards, supported by technical assistance and outreach efforts, to transform markets, resulting in energy cost savings of $\$ 1.1$ billion in 1998.

- Two hundred and fifty Rebuild America partnerships are pursuing energy-efficient retrofits of 800 million square feet of commercial floorspace. Estimates of energy cost savings from these retrofits in 1999 are $\$ 162$ million, showing the energy-efficiency payback that results when community networks are catalyzed.

- FEMP's innovative Energy Savings Performance Contracts (ESPCs) can now be used by federal agencies to contract with energy services companies to install energy-efficient systems and components, and pay for these improvements from the energy cost savings generated by the new systems. Since 1998, total contractor investment in the federal government is $\$ 405$ million.

- Working in cooperation with Bethlehem Steel, the DOE Office of Industrial Technologies demonstrated a number of energy-saving and environmentally sound technologies and processes at the Burns Harbor plant that may be replicated throughout the steel industry and are saving the company over $\$ 8$ million per year while reducing pollutant emissions.

- DOE's Industrial Assessment Centers, working through 30 universities, have provided over 7,600 energy and industrial process audits as of 1998 to small and mid-size manufacturing firms, generating recommendations that could save participating firms $\$ 300$ million by the year 2000 .

- Six recent demonstration projects where the DOE Motor Challenge Program provided technical assistance or advanced motor selection software to industry helped the firms install energy-saving motors in place of older, more energy-intensive units, thereby saving nearly $\$ 2$ million per year and paying for the changes in just over a year.

- The Clean Cities Program is a voluntary, locally based government/industry partnership to reduce the use of gasoline by accelerating the deployment of alternatively fueled vehicles. The 139,000 alternatively fueled vehicles that have been deployed over the past five years reduced gasoline and diesel fuel use by an estimated 380 million gallons through 1998, and reduced carbon emissions by an estimated 400,000 metric tons. Over the life of the program, approximately $\$ 900$ million worth of fuel has been saved.

- The National Biomass Ethanol Program has broken ground on the first commercial biomassto-ethanol plant in October 1998 in Jennings, LA. This is part of a DOE effort to expand the domestic ethanol industry and production of a low polluting alternative to gasoline by developing and demonstrating new conversion technologies using agricultural residues and energy crops. The use of ethanol blends in gasoline has displaced $\$ 12$ billion worth of oilbased fuels through 1998 . 


\section{SUMMARY ANALYSIS}

The activities in these 20 stories have received EERE funding of $\$ 712$ million, less than $10 \%$ of the approximately $\$ 8$ billion of EERE funds appropriated by Congress during the 1990s. Additional benefits have accrued from the balance of the budget that is not covered by this report's accomplishment metrics.

Looking at the bottom line in terms of energy, as represented in the graph below, these 20 R\&D and deployment successes have saved more than 5,500 trillion Btu, 5,050 trillion Btu from EERE R\&D successes, and almost 500 trillion Btu as a result of EERE field verification, deployment, and outreach successes. These savings are enough to meet the energy needs of all of the citizens, businesses, and industries located in the states of New York, Connecticut, and New Mexico, for one year (EIA, 1999a, Table 1). EERE technology and deployment programs have replaced another 1,700 trillion Btu of fossil fuels with renewable alternatives. This is equivalent to running all of the cars registered in the states of California, Florida, Mississippi, and West Virginia on ethanol rather than gasoline, for one year (Davis, 1999, Tables 2.6 and 2.11; Federal Highways Administration, 2000). Significant reductions in carbon emissions (103 million metric tons), have resulted from this decrease in burning fossil fuels.

\section{Energy Saved and Replaced by 20 Recent EERE Accomplishments}

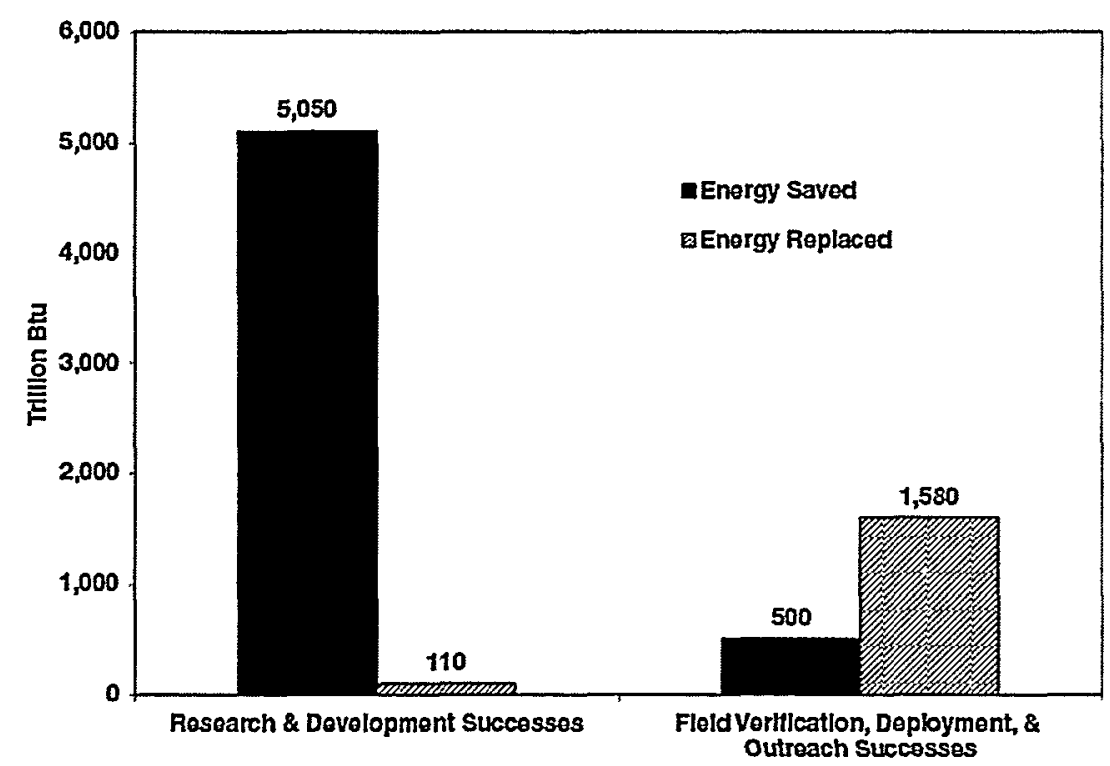

As an order of magnitude estimate, savings to the nation from these 20 activities are estimated to be approximately $\$ 30$ billion ( $\$ 1998$ ). This is based on the 5,500 trillion Btu of energy savings and the cost to consumers of an average Btu of energy consumed in 1998 (EIA, 1999b, Tables A2 and A3). In 1996, the General Accounting Office reviewed the success of five similarly situated technologies developed in the 1980s, and found a cumulative energy savings from all installations through 1996 to be $\$ 28$ billion, or over $\$ 3$ billion per year. All of these benefits will continue to grow as many of the technologies that have been commercialized with the support of EERE resources gain market share, and as emerging technologies achieve the technical breakthroughs and cost reductions necessary to successfully compete in the marketplace.

Compact fluorescent torchieres, spectrally selective glazings for windows, and lightweight materials for vehicles are examples of commercial products that are likely to produce much greater energy saving over the next decade than they have produced to date. Geothermal heat pumps installed through 1998 will replace 25 trillion Btu of grid-generated electricity and will save consumers $\$ 980$ million over the 
lifetimes of their operation. Wind turbine technologies are expected to replace significant amounts of fossil-fuel generated electricity capacity over the next several decades, leading to cleaner power and contributing to the nation's goal of energy security through fuel diversity.

\section{BENEFITS OF FUTURE PROGRAMS}

The following table is a reproduction of the estimated benefits of the EERE FY 2001 budget for DOE in terms of energy replaced, energy cost savings, and reductions in carbon emissions. Estimates are derived through EERE's Government Performance and Results Act (GPRA) methodology and are independently peer-reviewed.

\section{Projected Benefits of DOE's Office of Energy Efficiency and Renewable Energy FY 2001 Programs By Sector in the Year 2005, 2010, and 2020}

\begin{tabular}{|l|c|c|c|c|c|c|}
\hline & Industry & Transportation & Buildings & \multicolumn{2}{c|}{ FEMP } & \multicolumn{2}{c|}{ Power } & Totals \\
\hline & \multicolumn{7}{|c|}{ Total Primary Energy Replaced (quadrillion Btus) } \\
\hline $\mathbf{2 0 0 5}$ & .6 & $.2-.3$ & $.5-.6$ & .05 & $.3-.6$ & $1.65-2.15$ \\
\hline $\mathbf{2 0 1 0}$ & $1.4-1.5$ & $.9-1.0$ & $1.0-1.3$ & .07 & $.9-1.8$ & $4.27-5.67$ \\
\hline $\mathbf{2 0 2 0}$ & $3.8-4.8$ & 2.5 & $1.9-2.7$ & .07 & $2.5-4.3$ & $10.77-14.37$ \\
\hline & \multicolumn{7}{|l|}{ Energy Savings (\$ billions) } & & & \\
\hline $\mathbf{2 0 0 5}$ & $2.1-2.2$ & $1.7-3.3$ & 3.0 & .3 & $1.2-2.2$ & $8.3-11.0$ \\
\hline $\mathbf{2 0 1 0}$ & $5.5-6.8$ & $8.4-9.9$ & $8.4-10.3$ & .4 & $3.3-5.0$ & $26.0-32.4$ \\
\hline $\mathbf{2 0 2 0}$ & $17.3-19.3$ & $20.1-22.6$ & $15.0-21.7$ & .3 & $6.5-7.5$ & $59.2-71.4$ \\
\hline & Carbon Reductions (million metric tons) & & & \\
\hline $\mathbf{2 0 0 5}$ & $10.3-11.9$ & $3.8-4.6$ & $9.2-11.2$ & 1.0 & $2.7-12.1$ & $27.0-40.8$ \\
\hline $\mathbf{2 0 1 0}$ & $26.0-26.7$ & $17.9-19.5$ & $17.1-23.0$ & 1.2 & $15.3-35.5$ & $77.5-105.9$ \\
\hline $\mathbf{2 0 2 0}$ & $65.3-99.8$ & $46.0-50.1$ & $34.4-47.4$ & 1.2 & $45.1-88.3$ & $192.0-286.8$ \\
\hline
\end{tabular}

Where the benefits are expressed as a range of values, the upper point was determined based on analysis conducted by EERE's sectors and reviewed by Arthur D. Little, Inc. The sectors analyze the impacts their programs will have on energy savings, cost savings, and carbon reductions if all program goals are met. The lower point of each range for energy replaced and carbon reductions was derived from an integrated analysis model that controls for interaction effects. This model-driven analysis is conducted by contractors external to DOE. The integrated analysis model accounts for inter- and intra-sector doublecounting as well as market trends (i.e., reductions in new electricity generation). The lower point of the energy cost savings range is calculated by multiplying the total fossil primary energy replaced, derived from the integrated analysis, by the sector's ratio of energy cost savings to total primary fossil energy replaced for that year.

The total benefits projected for the year 2001 from the FY2001 budget are quite small and are primarily the result of EERE's partnership and deployment programs. By 2020 the projected impacts are substantial, reflecting large benefits from both partnership and $R \& D$ programs. The amount of primary 
energy replaced in the year 2020 is forecast to range from 10.8 to 14.4 quadrillion Btus, which is 9 to $12 \%$ of the 121 Quads that the United States is forecast to consume in the year 2020 (EIA, 1999b, Table 1, p. 7). The carbon reductions forecast for the year 2020 represents an even more significant percentage of the projected carbon emissions in 2020-ranging from 10 to $14 \%$ of the forecasted total emissions.

A recent report from an independent consulting firm (Arthur D. Little, 1999) determined that the energy savings and emission reduction estimates contained in this table are "realistic and credible." Arthur D. Little reviewed the information on projected energy savings and greenhouse gas emissions reductions to ensure the validity of estimates and assumptions. The report describes how the firm conducted the external review and concludes that the firm "believes that the estimates of the future benefits as summarized in this report are credible due to the rigorous review."

\section{CONCLUSION AND NEXT STEPS}

The accomplishments described in this report display positive impacts on real people and places that can be linked to EERE research, technology development, demonstration, and deployment activities. They document quantifiable, measured, tangible, and intangible impacts and benefits.

This report represents the most comprehensive effort taken to date to describe EERE's accomplishments and to quantify the benefits resulting from the nation's investment in its programs. EERE intends to increase the rigor of its future benefit-cost assessments and plans to report periodically on the successes of its programs. Recommended improvements include more rigorous documentation of costs, benefits and the impact of EERE involvement; more frequent application of cost-benefit analysis and case study methods, and more consistent cost and benefit assumptions and applications across EERE programs, so that results can be more easily aggregated.

\section{REFERENCES}

Arthur D. Little. 1999. Potential Climate Change Benefits of DOE Energy Efficiency and Renewable Energy Programs. (Cambridge, MA: Arthur D. little, Inc.), April.

Davis, S. 1999. Transportation Energy Data Book, Edition 19 (Oak Ridge, TN: Oak Ridge National Laboratory), September.

Energy Information Administration (EIA). 1999a. State Energy Data Report 1996, DOE/EIA-0214(96). U.S. Department of Energy, Washington, DC, February.

Energy Information Administration (EIA). 1999b. Annual Energy Outlook 2000: With Projections for 2020, DOE/EIA-0383 (00). U.S. Department of Energy, Washington, DC, December.

Federal Highways Administration. 2000. Website: www.fhwa.dot.gov/ohim/hs97/mv1.pdf, March. 


\section{RESEARCH AND DEVELOPMENT SUCCESSES}

Improvements in energy use and production technologies and practices through $R \& D$ programs provide the building blocks for a cleaner, more efficient and diverse energy economy. The imperative of investing in a strong $R \& D$ portfolio is reinforced by recognition of the long periods of time associated with significant changes in our energy infrastructure. Research and development itself often takes one or two decades to yield technological breakthroughs. The life expectancy of major energy supply and end-use technologies also extends to many decades. Investments made every day commit the nation to an energy path for what can be a considerable period of time. To the extent that economically attractive, clean, and efficient technologies are chosen, both the economy and the environment benefit. Thus, a robust energy $R \& D$ program is needed to enable the country to achieve a healthy and prosperous future.

EERE's strategy includes creating R\&D partnerships among energy companies, energy-intensive industries, universities, and our national laboratories to advance the development of new energy technologies and practices. Such R\&D alliances help maximize the efficiency of the technology R\&D process by leveraging public and private R\&D resources, and bringing together interdisciplinary teams of scientists, engineers, and analysts to deliver technology results acceptable to energy markets.

\section{A SAMPLE OF R\&D SUCCESSES}

This section describes 11 EERE R\&D successes resulting in commercialized technologies that are successfully competing in the marketplace.

\section{A Sample of Research and Development Successes}

\begin{tabular}{|c|c|}
\hline \multicolumn{1}{|c|}{ Buildings } & \multicolumn{1}{|c|}{ Industry } \\
\hline$>$ Compact Fluorescent Torchiere & $>$ Oxy-Fuel Fired Glass \\
\hline$>$ Ozone-Safe Refrigerants & $>$ Inventions and Innovations Program \\
\hline$>$ Spectrally Selective Glazings & Power \\
\hline \multicolumn{1}{|c|}{ Transportation } & $>$ Parabolic Troughs \\
\hline$>$ Lightweight Materials & $>$ Wind Turbine Advances \\
\hline$>$ Diesel Engines & $>$ Geothermal Heat Pumps \\
\hline & $>$ Transpired Solar Collectors \\
\hline
\end{tabular}




\section{Compact Fluorescent Torchiere}

Halogen torchiere lamps surged in popularity in the 1980s and 1990s. Their crisp white light, dimming capabilities, low glare, and low cost make them very attractive to consumers. As the number of halogen torchieres in use grew to an estimated 40 million, evidence of problems with the technology surfaced. The high operating temperatures of the lamp and the open reflector design create a fire hazard that has been blamed in as many as 260 fires and 12 deaths in the United States. The lamp's energy-intensive halogen bulbs, which use 300 to $500 \mathrm{~W}$, were by 1996 consuming roughly 16 billion $\mathrm{kWh}$ of electricity per year, the output of six typical $(500 \mathrm{MW})$ power plants.

DOE, working through researchers in the Energy-Efficient Fixtures Program at Lawrence Berkeley National Laboratory (LBNL), recognized the growing impact of halogen torchieres on residential energy use and realized that they could develop fixtures that offered the same attractive features, but used a more efficient light source that would also eliminate the fire hazard. LBNL researchers identified compact fluorescent lamps (CFLs) as a suitable alternative and set out to develop an appropriate design.

DOE/LBNL worked initially with several major lamp and ballast manufacturers and later with a small, entrepreneurial company to develop a prototype and accelerate commercialization. This product turned out to be well suited to market needs and stimulated other manufacturers to develop and introduce similar products.

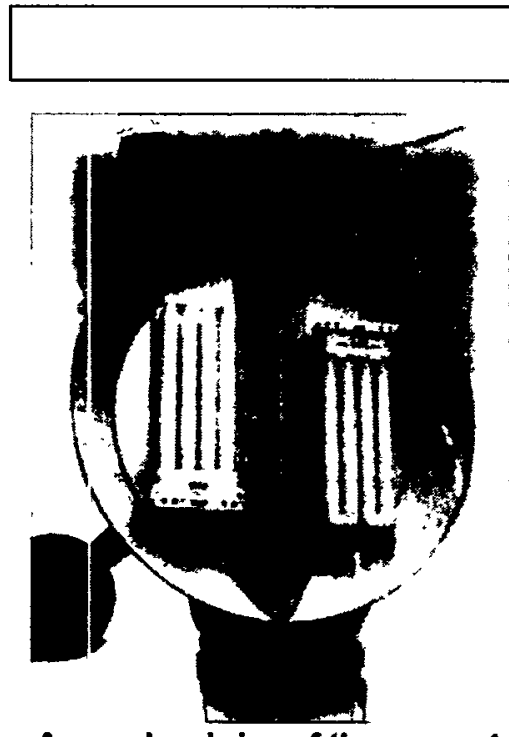

An overhead view of the compact fluorescent torchlere developed by the LBNL fixtures lab.

\section{The DOE Role}

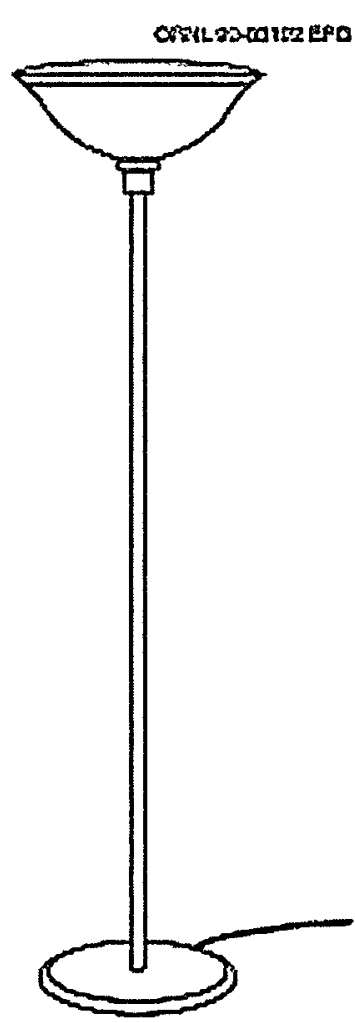

In 1995, LBNL researchers ran a series of tests on halogen torchieres. Infrared thermography was used to determine heat output. A swing-arm goniophotometer, developed at LBNL, was used to measure light output and the distribution of light. Power, power factor, and total harmonic distortion were also measured. Working with these test results, the researchers built several CFL-based torchiere prototypes with a variety of lamp and reflector configurations. Their best design used two 36-W F-type lamps to produce $50 \%$ more light than a 300 -W halogen torchiere with only $25 \%$ of the energy consumption. With Emess Lighting Inc., LBNL worked to determine which prototype would provide the best light with the simplest design and easiest manufacturing process. Energy Federation Incorporated (EFI) also worked with LBNL to optimize the reflector in their torchiere design. LBNL's input was invaluable to light fixture manufacturers, who generally lack technical expertise in compact fluorescent or other lamp technologies.

Lab researchers and manufacturers agree that LBNL's involvement acted as a catalyst, accelerating the commercialization of the alternative torchieres. Emess Lighting had experience developing fixtures for compact fluorescent lamps, but operating problems and the high costs associated with early CFL technologies had undermined their efforts. As a result, the company was hesitant to take a leading role with a new product unless the technology was clearly ready and its marketability proven. LBNL's research showed how advances in lamp quality and electronic ballasts had led to CFL technology that could exceed the performance of the halogen torchiere, would pose no safety problem, and would use far less energy. To assure manufacturers that a market existed for CFL torchieres, DOE and LBNL identified volume markets for the technology: universities, military bases, and commercial buildings. They also 
played an important role in establishing CFL torchiere "swaps" and fixture installations on two university campuses and at Bolling Air Force Base.

Five manufacturers have introduced CFL torchieres with a range of styles and prices (compared in Table 1). All qualify for the Energy Star Residential Fixtures labeling program, and some utilities are sponsoring discounts. The lamps can now be purchased through a variety of retail outlets and websites. Some websites automatically calculate any utility rebates and deduct the rebate from the lamp's cost. LBNL's CFL torchiere design was awarded the 1997 Popular Science "Best of What's New" Grand Prize Award for Home Technology.

Table 1: Product Comparison

\begin{tabular}{lccc}
\hline \multicolumn{1}{c}{ Manufacturer } & Lamp Watts & $\begin{array}{c}\text { Light Output } \\
\text { (lumens) }\end{array}$ & $\begin{array}{c}\text { Dimmabilityl } \\
\text { Switchability }\end{array}$ \\
\hline Standard Halogen & 300 & 3,500 & full dimming \\
\hline Catalina Lighting & 67 & 4,200 & full dimming \\
Emess Lighting & 72 & 4,200 & $100 \%, 50 \%$ \\
Energy Federation Inc. & 52 & 3,600 & $100 \%, 50 \%$ \\
Energy Federation Inc. & 78 & 4,200 & $100 \%, 66 \%, 33 \%$ \\
Good Earth Lighting & 67 & 4,200 & full dimming \\
Lights of America & 50 & 4,050 & $100 \%, 62 \%, 38 \%$ \\
\hline
\end{tabular}

The LBNL Energy Efficient Fixtures Program is building on its strong relationship with the lighting industry by offering their assistance to companies seeking to commercialize energy-efficient lighting products. The lighting industry has expressed a strong interest in furthering this relationship with LBNL.

\section{Benefits and Costs}

A leading fixture manufacturer estimated total sales of the CFL torchieres at 5,000 in 1997 and growing to 200,000 in 1998 . Others predict sales reaching one million units per year within the next few years. CFL torchieres (using 55 to $78 \mathrm{~W}$ ) sell for $\$ 48$ to $\$ 159$ retail; halogen torchieres sell for an average of $\$ 20$. Despite its higher initial cost, the life cycle costs of the CFL torchiere demonstrate its costeffectiveness, with a payback period of less than two years, based on cost of $\$ 70$ (versus $\$ 20$ for a halogen torchiere); CFL lamp life of 10,000 hours (versus 2,000-hour life with a $\$ 6$ replacement cost for halogen lamps); lamp usage of 4 hours per day; and electricity cost of $\$ 0.08$ per $\mathrm{kWh}$.

The electricity saved in 1998 from the sale of 200,000 CFL torchieres (instead of halogen torchieres) is an estimated 69 million $\mathrm{kWh}$. The electricity saved over the seven-year life of the 200,000 lamps is estimated to be 480 million $\mathrm{kWh}$ (or the equivalent of 5.2 trillion Btu). Every halogen torchiere replaced by a CFL torchiere also represents the removal of a fire hazard and the prevention of fires, loss of lives, and property damage. DOE invested approximately $\$ 300 \mathrm{~K}$ in $\mathrm{R} \& \mathrm{D}$ on compact fluorescent torchieres between 1995 and 1997.

\section{For More Information}

Website: http://eetd.lbl.gov/BTP/torchoverview.html

Geller, Howard, and Jennifer Thorne. 1999. "U.S. Department of Energy's Office of Building Technologies: Successful Initiatives of the 1990s." American Council for an Energy Efficient Economy: Washington, D.C. , www.aceee.org/pubs 


\section{Ozone-Safe Refrigerants}

In the late 1980 s and early 1990 s, manufacturers of refrigeration equipment-refrigerators, freezers, air conditioners, and heat pumps-faced several challenges. First, the manufacture and use of chlorofluorocarbons (CFCs) would be phased out as of December 31, 1995, under the Montreal Protocol on Ozone-Depleting Substances. Second, appliance standards mandated by the National Appliance Energy Conservation Act of 1987 (NAECA) would take effect in 1993, requiring significant advances in energy efficiency. To further complicate matters, some of the early alternatives to CFCs increased energy consumption and were linked to global warming.

DOE responded to these challenges by initiating programs of joint research and development with the chemical,

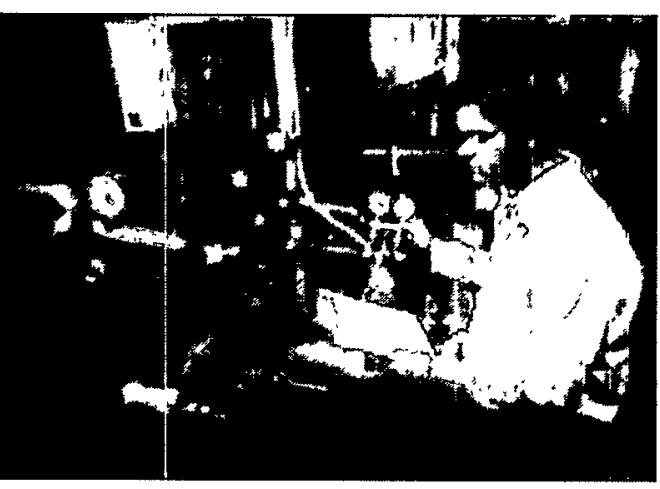

An ORNL engineer, Ed Vineyard, checks instrument readings during a test of chlorine-free refrigerant mixtures. appliance, and air conditioning industries. DOE's leadership galvanized industry resources and pulled together federal $R \& D$ capabilities to address the problem. The research on ozone-safe refrigerants resulting from these collaborations accelerated the entry of alternative refrigerants in commercial applications, allowing U.S. industry to phase out CFCs two years before the Montreal Protocol deadline and to meet NAECA requirements, and saving an estimated $\$ 16$ billion in energy expenditures.

\section{The DOE Role}

Beginning in 1985, DOE funded Oak Ridge National Laboratory (ORNL) to evaluate potential replacements for CFC refrigerants. Researchers analytically screened over 200 compounds and selected 14 that were also acceptable in terms of properties such as volatility, flammability, stability, and boiling point range. Several refrigerant suppliers synthesized these compounds for testing. Researchers at ORNL's Alternative Refrigerants Calorimeter Facility tested sample quantities of CFC-replacement fluids, measuring the energy performance and cooling capacity of each. Based on their results, ORNL researchers suggested changes in the composition of refrigerant blends to their industry collaborators, who produced the new blends for further testing.

Beginning in 1987, DOE also funded the National Institute of Standards and Technology (NIST) to conduct basic research into the fundamental thermophysical properties of refrigerants, along with systems testing, modeling, and evaluation of hardware. Early results from ORNL and NIST indicated that existing replacements for $\mathrm{CFC}$ refrigerants could increase the energy consumption of refrigerators by $8 \%$. This potential energy penalty sounded an alarm in the appliance industry, which was facing deadlines for compliance with new NAECA standards. DOE and its industry collaborators took the news as fair warning and accelerated research efforts on all fronts.

Phasing out ozone-depleting refrigerants was more complex than simply identifying new refrigerants. Bottom-line performance depended on thousands of interacting variables, and the wished-for "drop-in" replacements for CFCs failed to materialize quickly. One important obstacle, in terms of both mechanical factors and energy efficiency, was the incompatibility of the CFC alternatives with the lubricants and materials used in existing equipment designs. One incompatibility identified by ORNL's research could have imposed a $45 \%$ energy penalty. DOE addressed this issue in 1991 by funding the Material Compatibility and Lubricant Research (MCLR) program to identify lubricants and materials suitable for 
use with alternative refrigerants. This program was jointly managed by DOE and the Air Conditioning and Refrigeration Technology Institute (ARTI).

Prior to the DOE support to ARTI there had been no publicly accessible compilation of information on what had been accomplished in terms of research and testing of new refrigerants, lubricants and their effects on equipment materials. As part of the MCLR activities, the ARTI established a Refrigerant data base that is a comprehensive reference source of published reports and includes the results of over forty research projects from the DOE/ARTI MCLR research. This data base now contains more than 6100 entries and has been a primary source of information on new refrigerant issues for the industry.

The Heat Pump Design Model, a public-domain computer program developed by ORNL, was an important tool in developing safe and effective CFC alternatives and working with industry to redesign equipment to work with those refrigerants. The program was used in ORNL's studies and by manufacturers representing over a third of the U.S. air conditioner and heat pump market to determine capacity and efficiency of new refrigerants by modeling their operation in alternative equipment designs. DOE's leadership brought into play the resources needed for a successful industry-government R\&D effort that led to the development of optimized, environmentally friendly refrigerants for energy-efficient appliances. In a letter of appreciation to DOE, ARI's Vice President of Research and Technology applauded the excellent government/industry partnership and the "approach of conducting precompetitive research, the results of which industry can tailor to its needs."

\section{Benefits and Costs}

All of the refrigerators, freezers, air conditioners, and heat pumps now available to consumers use refrigerants, developed by industry in collaboration with $\mathrm{DOE}$, that cause little or no damage to the stratospheric ozone layer. According to industry, DOE's collaborative research made it possible for the United States to complete an early phase out of CFCs in many applications by 1994, two years earlier than required. Without DOE's program of collaborative research, the United States would have paid a huge price for a sacrifice in energy efficiency.

Without DOE's collaboration with industry to accelerate the identification of these alternatives and to adapt equipment to maintain the energy efficiency achieved in appliances using CFC refrigerants, the nation's energy use would have increased by 1 to 2 quads per year in the mid-1990s. Using the more conservative estimate of 1 quad of savings per year and assuming 2 years of benefits results in an estimated total energy savings of 2 quads. This is equivalent to a $\$ 16$ billion savings in the nation's energy expenditures. The early development of CFC substitutes in the United States also helped increase exports of air-conditioning and refrigeration products.

DOE invested approximately $\$ 15$ million in R\&D on ozone-safe refrigerants between 1985 and 1998.

\section{The Big Picture}

In addition to meeting its near-term goals, this DOE R\&D program helped lay the groundwork for appliance manufacturers to meet the higher efficiency standards that will be effective in 2001 .

\section{For More Information}

DOE Office of Building Technology, State and Community Programs-Advanced Refrigeration Program: www.ornl.gov/ORNL/BTC/warming.html

Vineyard, E.A., J. R. Sand, and T. G. Statt. 1989. "Selection of Ozone-Safe, Nonazeotropic Refrigerant Mixtures for Capacity Modulation in Residential Heat Pumps," ASHRAE Transactions 95(1), 34-46. 


\section{Spectrally Selective Glazings}

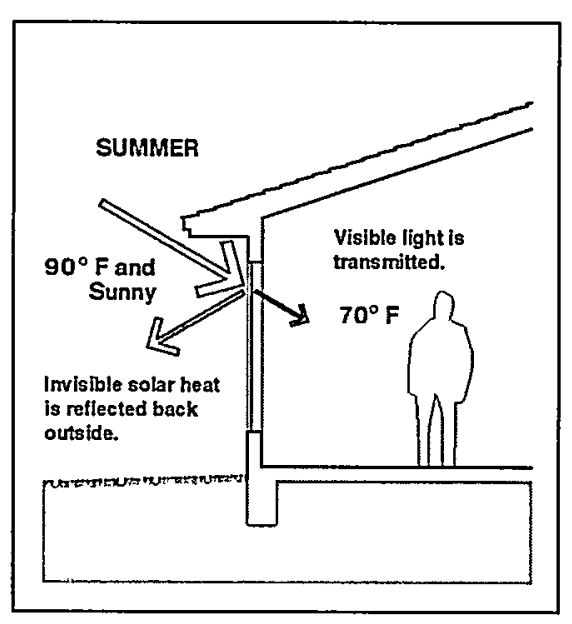

Since helping to develop the first generation of low-emissivity (low-E) window coatings, DOE has continued to work with glass and window manufacturers on spectrally selective coatings for warmer parts of the country. Spectrally selective coatings admit as much daylight as possible while blocking transmission of ultraviolet and infrared "heat" radiation, thereby reducing solar heat gains in summer while still preventing loss of interior heat in winter. The opportunity for spectrally selective glazings is illustrated by the fact that low-E windows have a residential market share of $50 \%$ or more in the northern regions of the country, but only $20 \%$ or less in the Southeast and Southwest.

Caption: Spectrally selective windows can cut cooling costs in hot climates by 10 to $25 \%$

\section{The DOE Role}

In the mid-1980s, Lawrence Berkeley National Laboratory (LBNL) analyzed the energy impacts of windows in typical houses throughout the United States, showing that reducing solar heat gain in hotter climates could substantially cut energy costs, and that even in colder climates cooling costs due to windows were significant. This information helped convince Cardinal IG, a major glass manufacturer, to introduce solar control low-E glazings and Andersen Windows to adopt solar control low-E on a wide scale.

DOE's national laboratories worked to bring spectrally selective glazings into the mainstream window markets during the late 1980s and early 1990s through their technical studies and interactions with the windows and glass industry:

- A workshop in 1992 to publicize the benefits of the technology and to showcase product offerings, applications, and marketing opportunities was organized by LNBL in 1992. Utilities began to subsidize the costs of spectrally selective glazings as part of their demand-side management programs.

- LBNL tested several spectrally selective glazings in the mobile window thermal test facility (MoWiTT) to verify their energy performance. These tests demonstrated to window manufacturers, utilities, and code officials that the effects of these invisible coatings were real.

- LBNL's computer model, WINDOW, used throughout the industry to quantify performance of windows, was upgraded to properly characterize this new class of spectrally selective products.

- The National Renewable Energy Laboratory evaluated the impacts of spectrally selective glazings on cooling energy use in actual homes in hot climates. This demonstration of energy and cost savings boosted industry marketing efforts, and encouraged the building industry to adopt selective glazings and more utilities to include windows in their demand-side management programs.

In the 1990s, DOE contributed to rating and labeling efforts to ensure that the performance of selective glazings is accurately represented to consumers, architects, and specifiers. LBNL worked with the glass industry to develop procedures for measuring glass properties and a database of these properties. This database, used in conjunction with the WINDOW program, was tied in with National Fenestration Rating Council (NFRC) procedures for accurately rating spectrally selective glazing products. NFRC established and implemented the rating, labeling, and certification program. 


\section{Benefits and Costs}

Spectrally selective windows are one piece of the puzzle in the "whole-buildings" approach of DOE's Building Technologies, State and Community Programs (BTS). Building America and other BTS programs are developing the next generation of energy-efficient houses, which will use at least $30 \%$ less energy than the standards set in the 1998 Model Building Code. Designs for these houses generally start with spectrally selective low-E windows because of their central place in the energy equation. Using these windows plus extra insulation decreases the need for heating and cooling so that smaller, less expensive HVAC systems can be used, which lowers construction costs as well as saving energy. Spectrally selective low-E windows are also chosen because they significantly increase thermal comfort and reduce condensation, benefits that may seem even more important to some occupants than energy savings.

Today spectrally selective products are manufactured by the major glass manufacturers and some films manufacturers and are used in about $15 \%$ of new low-E windows. Simulations, tests, and monitored buildings demonstrate that using solar control windows can reduce cooling energy use in air-conditioned homes by $10-25 \%$, depending on climate and site shading. They can also reduce lighting energy use in commercial buildings because they transmit more visible light than the conventional tinted films used to cut solar heat gains.

Retrofitting with selective glazings can pay back in four to ten years for commercial buildings in most parts of the United States. The payback is even faster in new buildings where the incremental cost is lower and the air conditioning system can be downsized. Double-pane glazing with a spectrally selective coating costs 10 to $20 \%$ more than ordinary double-pane glazing. Using spectrally selective windows in retrofit applications where labor accounts for a significant proportion of the cost adds only about $5 \%$ to the total price of the job.

If all new windows sold in hotter climates had spectrally selective coatings, cooling energy use in 2010 due to heat gains through windows would fall by about 0.19 quads, a $39 \%$ savings. At the projected price of electricity in 2010 ( $\$ 0.073 / \mathrm{kWh}$ in 1996 dollars), this implies energy bill savings of $\$ 1.3$ billion per year. If all new windows sold throughout the country contained spectrally selective coatings, heating energy use due to windows would be reduced by about 0.24 quads $(19 \%)$ in 2010 . With projected energy prices for heating fuels, this savings would be worth about $\$ 1.2$ billion per year. Thus, full adoption of spectrally selective coatings in new residential windows could potentially result in total (heating and cooling) savings of about $\$ 2.5$ billion per year by 2010 .

DOE invested $\$ 3$ to 4 million in R\&D and rating and labeling efforts in support of spectrally selective glazings from 1986 through 1996. DOE continues its efforts to accelerate the deployment of energyefficient windows through its support of the Efficient Windows Collaborative (EWC), an organization with more than 50 members, including the leaders of the window and glass industries who are committed to manufacturing and promoting energy-efficient windows. The EWC's Efficient Windows web site is supported by DOE's Windows and Glazings Program and the EWC's collaborating members. This web site provides unbiased information on the benefits of energy-efficient windows, descriptions of how they work, and recommendations for their selection and use.

\section{For More Information}

Efficient Windows Collaborative web site: www.efficientwindows.org

Klems, J. H., M. Yazdanian, and G. O. Kelley. "Measured Performance of Selective Glazings." Proceedings of Thermal Performance of the Exterior Envelopes of Buildings VI, Clearwater Beach, Fl, 1995. 


\section{Oxy-Fuel Fired Glass}

The Office of Industrial Technologies (OIT), working in close cooperation with industrial partners, contributed $\$ 1$ million in 1991 to demonstrate the practical application of research and development on oxygen-fueled glass furnace technologies. The success of the demonstration confirmed the commercial viability of oxy-fuel firing, encouraging the widespread adoption of this process. In 1999 approximately 30 percent of all glass made in the U.S. comes from oxy-fuel fired furnaces. The annual energy savings attributed to oxy-fuel systems in the U.S. in 1997 was over 3.4 trillion Btu, an annual savings of \$7.2 million, and cumulative energy savings through 1997 totaled 13 trillion Btu, a savings of $\$ 27.5$ million. Cumulative carbon reductions attributed to oxy-fuel firing total $0.19 \mathrm{MMT}$.

\section{Success in Reaching Energy and Environmental Goals}

OIT funds R\&D and disseminates objective data that improves glass making, determining research priorities with the OIT Glass Team's industrial and university partners. OIT engages these partners in workshops and symposia. A participant from glassmaker Corning commented on one such workshop: "I was particularly impressed by the size and diversity of this gathering, the candidness of the participants, and the positive, cooperative spirit that prevailed throughout the proceedings. There was a strong sense that, working together, we can find technical solutions to the remaining challenges posed by oxy-fuel technology and the net savings will be well worth the effort."

OIT-funded research in combustion includes burner design, sensors, modeling, and refractories. DOE's continuing support of the oxy-fuel process was demonstrated in 1997 through the award of $\$ 17.4$ million for cost-shared glass production research. Three of the five projects funded focus on the oxy-fuel

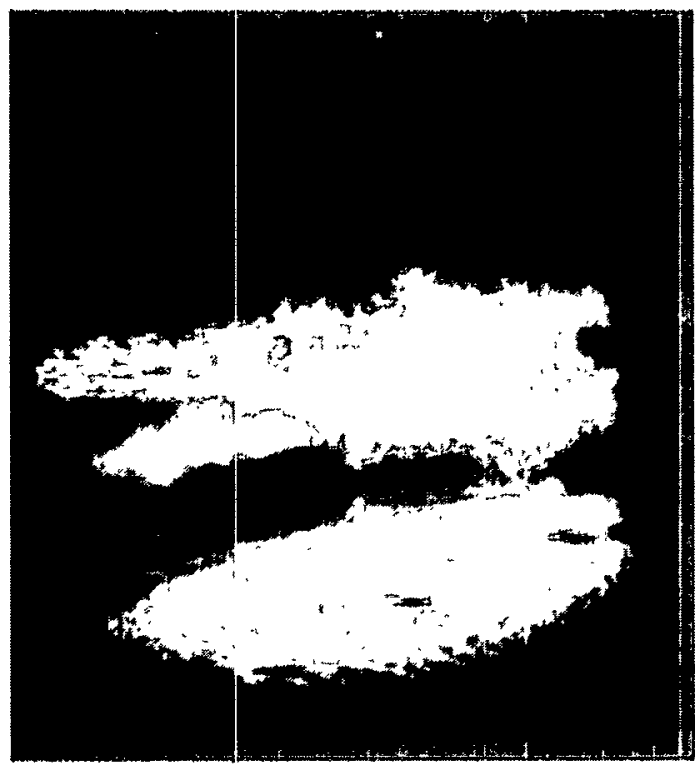

An ultra-low $\mathrm{NO}_{x}$ burner firing fuel and oxygen into a rolled flat-glass furnace. process. The projects aim to extend the lifespan of furnace refractories, improve burner and sensor designs, develop expert systems controls, and improve the economics of oxygen production.

Oxygen enrichment of glass furnace fuel streams is key to industry reaching its energy and environmental goals. Glass production is an energy- intensive process. In 1994, the domestic industry consumed over 200 trillion Btu of process energy at a cost of more than $\$ 1.3$ billion. The production of glass also presents considerable environmental challenges. By using oxygen instead of air, oxy-fuel firing can cut $\mathrm{NO}_{\mathrm{x}}$ emissions more than 80 percent, lower particulate emissions by 25 percent, and reduce furnace energy requirements.

\section{Benefits and Costs}

The remarkable benefits generated to date foreshadow the benefits expected from present research efforts:

- By retrofitting oxy-fuel firing technology to a wine manufacturers' bottle production facility, OIT and its industrial partners achieved energy savings of 25 percent while reducing $\mathrm{NO}_{\mathrm{x}}$ emissions by over 
80 percent and particulate emissions by about 25 percent. OIT contributed $\$ 1$ million to the demonstrations' $\$ 1.409$ million budget.

- Typical oxy-fuel systems can now be installed at average capital costs of $\$ 50$ to $\$ 100$ per annual ton of oxygen capacity, with a simple payback of 2-4 years.

\section{For More Information}

For more information on how oxy-fuel firing is meeting the energy and environmental goals of the glass industry, please visit OIT's Glass Industry of the Future website at http://www.oit.doe.gov/glass/ 


\section{Inventions and Innovations Program}

The Inventions and Innovations Program (I\&I) was established in 1974 to assist the development of inventions not related to nuclear energy and having outstanding potential for saving or producing energy. Since then, over 32,000 inventions have been evaluated by the National Institute of Standards and Technology for technical merit, and about 740 have received commercialization and financial assistance from DOE. Approximately 500 of these have been supported by DOE grants.

Lenox Polymers, a Michigan-based start-up firm, benefited from one such grant. Financial and technical support provided by the Department of Energy's Office of Industrial Technologies' Inventions and Innovations (I\&I) program, a component of the Energy-Related Inventions Program, allowed Lenox Polymers to develop specialty

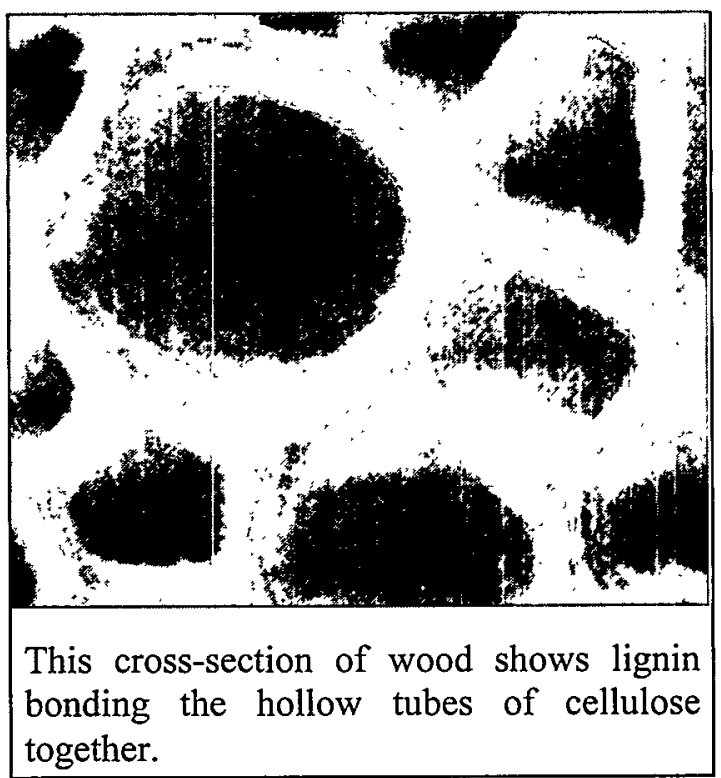
performance resins using lignin. Lignin, the natural glue that holds together tree fibers (shown here), is extracted from a by-product of paper mills called black liquor. Lenox Polymers now manufactures resins that save valuable petrochemical resources that are used to produce traditional petroleum-based resins. The company's products are now used in over 20 different applications, and sales for the start-up company topped $\$ 500,000$ in 1997.

\section{The Lenox Polymer Story}

In 1984, the Inventions and Innovations program awarded Lenox Polymers a \$96,914 grant to support development of a patented, domestically produced, renewable product. This grant covered about 10 percent of the development costs, including proof of concept and scale-up of the resin production process from the laboratory to commercial pilot scale.

The feedstock for Lenox resins is black liquor, a byproduct of pulp and paper mills. Roughly 50 billion tons of black liquor is produced each year; 90 percent of this is used within the mill, leaving about 10 percent available for use in the Lenox process. Using even a fraction of these 5 billion tons of excess black liquor will provide not only useful products from waste, but also relieve overloading of wood pulp recovery boilers. Lenox' natural polymer is environmentally friendly and free of potentially carcinogenic substances such as formaldehyde, phenol, and styrene found in oil-based substances.

There are many applications for the Lenox resins. They can be used as foundry resins for metalcasting, wood particulate binders (for plywood and particleboard), and in compression molding polymer systems. When Lenox polymers are used in foam materials, the foam materials have a darkened color, but are also moisture resistant, flame and heat resistant, and have higher strength and toughness. By replacing polyesters and polyurethane resins, nitrous oxide $\left(\mathrm{N}_{2} \mathrm{O}\right)$ emissions related to the production of these petrochemical-based resins will be cut by 4.2 to 8.4 thousand metric tons by the year 2010 . 


\section{Benefits and Costs}

The success of Lenox Polymers is not unique. Since the inception of the Inventions and Innovations Program, DOE and Oak Ridge National Laboratory have monitored and documented the commercial progress of supported inventions and innovations (Perlack et al., 1998). Of those inventions supported by grants, $25 \%$ have had commercial sales - a success rate generally higher than technological innovations overall. Total cumulative direct and licensed sales through 1996 now exceed $\$ 700$ million (1995\$); cumulative sales of spin-off technologies have reached $\$ 90$ million (1995\$). Program expenditures total \$84 million through 1996.

As shown below, the inventions program has generated a 20:1 return in terms of the ratio of sales to grant dollars and an 8:1 return in terms of ratio of sales to total program expenditures. In 1996, I\&I inventions supported the equivalent of nearly 1,200 full-time jobs, generating over $\$ 6$ million in federal income taxes (i.e., more than I\&I's annual appropriations). Energy savings attributable to grant-funded inventions were estimated at 80 trillion Btu, which amounts to a savings of $\$ 190$ million (1995\$). The reduction in carbon emissions associated with these commercially successful inventions exceeded 1.6 million metric tons in 1996.

Congressional appropriations for the program have totaled $\$ 84$ million (in 1995\$) from 1980 through 1996.

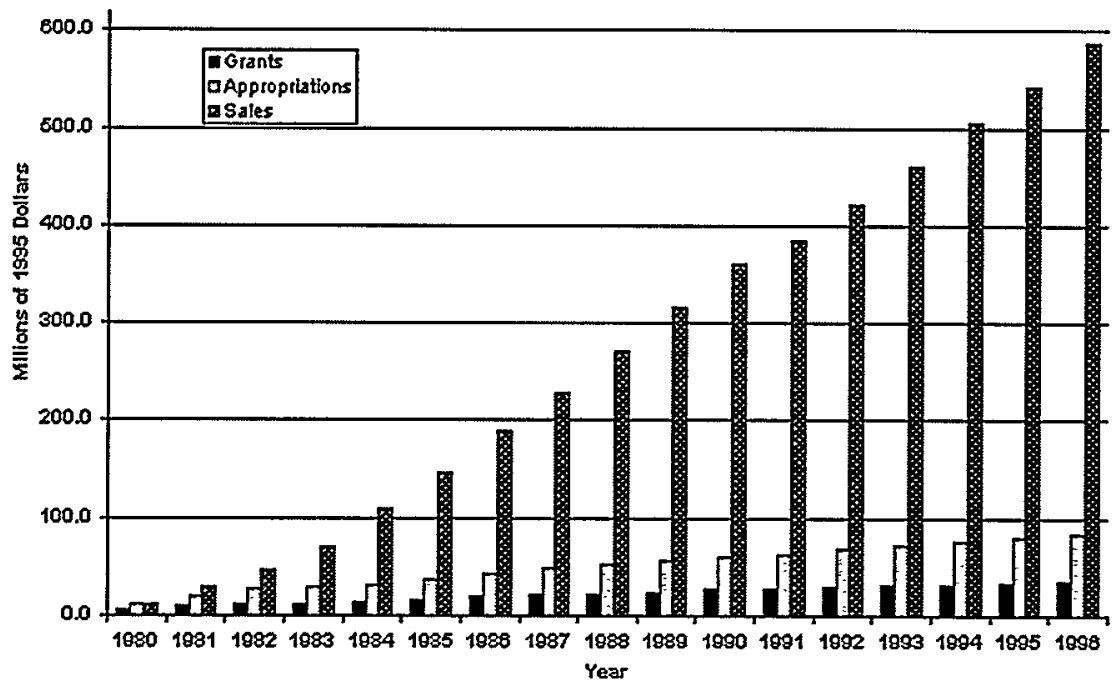

\section{Cumulative grants, appropriations, and sales associated with DOE's inventions program.}

\section{For More Information}

Perlack, R.D, C.G. Rizy, C.A. Franchuk, S.M. Cohn, Commercial Progress and Impacts of Inventions and Innovations, (Oak Ridge, TN: Oak Ridge National Laboratory), August 1999.

U.S. Department of Energy, Office of Energy Efficiency and Renewable Energy, Office of Industrial Technologies, "Inventions \& Innovation Success Story - Environmentally-Friendly Polymer Replaces Petroleum Based Resins, available at http://www.oit.doe.gov/inventions/pdfs/lennox.pdf 


\section{Lightweight Materials for Automobile Structures}

Automobiles account for almost two-thirds of the nation's gasoline consumption and about one-third of total U.S. energy use. About $75 \%$ of a vehicle's fuel consumption is directly related to factors associated with weight. Heavier vehicles use larger engines, bulkier drivetrains, and more massive chassis, and require more energy to accelerate, decelerate, and overcome rolling resistance. They also deliver more kinetic energy to other vehicles in automotive crashes.

Lightweight materials are critical to the development of highly fuel-efficient vehicles. Since 1991, the DOE has worked with automobile manufacturers and their suppliers to develop lighter materials for primary structural applications. The challenge facing these programs is to produce lighter materials at production rates and costs comparable to those of current materials. DOE's objective is a $50 \%$ average weight reduction in body and chassis of $50 \%$ by 2004 and a $60 \%$ by 2011 .

\section{DOE Role and Technology Description}

Using currently available lightweight materials could reduce vehicle weight by more than $60 \%$. However, the cost of these materials, design capabilities, and associated manufacturing processes are still inadequate to produce cost-effective vehicles. Research supported by DOE is focusing on new, reliable joining technologies, lower-cost aluminum sheet materials, high-volume production technologies for fiber-reinforced composite materials, more reliable continuously cast aluminum components with improved performance capabilities, and innovative processing technologies for lower-cost carbon fiber materials. The goal is to give automotive designers multiple material options for future structures by removing technical and economic obstacles to producing advanced materials.

Metals and reinforced polymers are the two families of materials now under development. Among the metals, magnesium alloys and aluminum have the highest priority; metal matrix composites, titanium alloys, and intermetallics are important in longer-range plans. Among the polymers, reinforced thermosets and lower-cost, high-stiffness reinforcements are the highest priorities, with advanced thermoplastic materials being important for future development.

New technologies for working with these advanced materials must also be developed. Standard processes

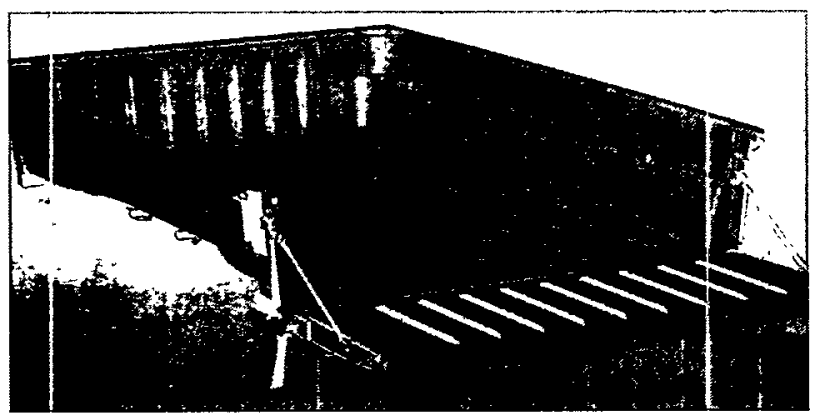
must be adapted or new ones developed to optimize quality and performance. New design methodologies and performance models as well as rapid, cost-effective, production-scale processes for the new materials will also be needed. Additional knowledge is needed regarding recycling of materials, joining technologies, crash performance, material durability, and lifetime performance.

Glass-fiber-reinforced all-composite pickup truck bed

\section{Benefits and Costs}

Benefits. Automobile companies have done an exceptional job of reducing the weight of vehicles over the last two decades-partly by making smaller cars, which has reached its limits of consumer acceptance, and partly by incorporating nonferrous materials into secondary vehicle systems. Average automobile weight has been reduced by nearly $25 \%$ while fuel economy has doubled. DOE's efforts to develop light weight materials such as aluminum for automobile applications have saved more than 6.0 billion gallons of motor fuel and reduced carbon emissions by 15 million metric tons. The dollars saved in oil-based fuels over the period from $1978-1997$ is estimated at about $\$ 7$ billion. 
More extensive use of lightweight materials will further improve automobile fuel efficiency. There is still significant potential to reduce the weight of the primary (load bearing, crash critical) structural components, which are made almost exclusively of ferrous materials. In general, every $10 \%$ reduction in weight leads to a $6 \% \mathrm{mpg}$ gain.

\begin{tabular}{lccc}
\hline System & $\begin{array}{c}\text { Current reference vehicle } \\
\text { weight (lb) }\end{array}$ & $\begin{array}{c}\text { Vehicle target } \\
\text { weight (lb) for 2004 }\end{array}$ & Mass reduction \\
\hline Body & 1,134 & 566 & $50 \%$ \\
Chassis & 1,101 & 550 & $50 \%$ \\
Powertrain & 868 & 781 & $10 \%$ \\
Fuel/other & 137 & 63 & $55 \%$ \\
\hline Curb weight & 3,240 & 1,960 & $40 \%$ \\
\hline
\end{tabular}

Costs. The next steps in reducing the weight of cars will require significant capital investment by suppliers to the automobile industry to increase the production of materials such as aluminum and magnesium and to expand industries to produce carbon-fiber-reinforced materials. For example, to produce the carbon fiber potentially needed to meet demands in 2015 could require an investment of $\$ 4.6$ billion. Retooling the automobile industry to use lighter materials will also require significant investment capital, but will likely occur with normal retooling as equipment life cycles end. There will be costs associated with developing the infrastructure necessary to repair, recycle, and dispose of these materials.

The cumulative DOE investment in aluminum lightweight materials from 1978 through 1997 was about $\$ 40$ million. Private investment will be much greater and heavily concentrated in technology implementation.

\section{The Big Picture}

The OAAT strategy focuses on researching, developing, and validating technologies to produce marketcompetitive automobiles with dramatically improved fuel efficiency and no increase in emissions. OAAT aims to develop an $80-\mathrm{mpg}$, five-to-six-passenger vehicle by 2004 and, by 2011, six-passenger alternative-fuel vehicles that achieve zero emissions and $100 \mathrm{mpg}$. In addition to developing advanced materials, OAAT will sponsor development of advanced propulsion system technologies, advanced heat engines, fuel cells, high-power energy storage, power electronics, new fuels, and electric power batteries. Key performance milestones for lightweight materials technology R\&D through 2011 are charted below.

\begin{tabular}{|l|l|l|l|l|l|}
\hline \multicolumn{1}{|c|}{1994} & \multicolumn{1}{|c|}{1998} & $\mathbf{1 9 9 9}$ & $\mathbf{2 0 0 0}$ & \multicolumn{1}{c|}{$\mathbf{2 0 0 4}$} & \multicolumn{1}{c|}{$\mathbf{2 0 1 1}$} \\
\hline $\begin{array}{l}50 \% \text { weight } \\
\text { reduction at } 2 \times \text { cost } \\
\text { of steel body and } \\
\text { chassis }\end{array}$ & $\begin{array}{l}50 \% \text { weight } \\
\text { reduction at } 1.5 \times \\
\text { cost of steel body } \\
\text { and chassis }\end{array}$ & & & $\begin{array}{l}50 \% \text { weight } \\
\text { reduction at } 1 \times \text { cost }\end{array}$ & $\begin{array}{l}60 \% \text { weight } \\
\text { reduction at } 1 \times \text { cost }\end{array}$ \\
\hline
\end{tabular}

To reach these milestones, $R \& D$ activities are transitioning from developing glass-reinforced polymeric matrix composites to developing lighter carbon-fiber-reinforced polymeric matrix composites. In addition, research is focusing on using lighter metal-matrix composites for brakes, titanium for springs, and magnesium for joints.

\section{For More Information}

Office of Transportation Technologies, Office of Energy Efficiency and Renewable Energy, Department of Energy, Office of Advanced Automotive Technologies R\&D Plan, Energy-Efficient Vehicles for a Cleaner Environment, March 1998. 


\section{Cleaner and More Efficient Diesel Engines}

Trucks-pickups, sports utility vehicles (SUVs), and heavy freight hauling trucks-are the fastest growing fuel consumers in the transportation sector. Large-displacement compression-ignition diesel engines are the most fuelefficient engines available to heavy vehicle manufacturers and operators. Current diesel engines offer peak thermal efficiencies of 44 to $45 \%$, far above the $30 \%$ efficiency of conventional spark-ignited engines. Putting diesel engines in lighter trucks (classes 1-3) would offer significant fuel savings. DOE-sponsored R\&D activities are performed in conjunction with industry and focus on enhancing the efficiencies of diesel engines for light and heavy trucks.

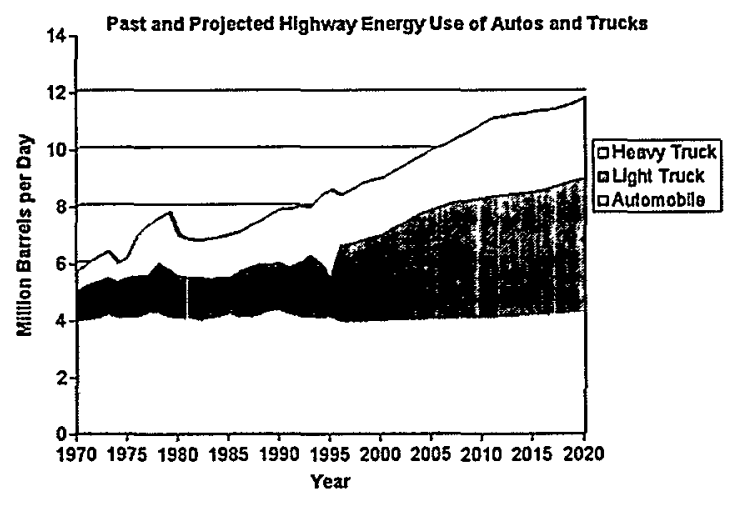
Greater fuel efficiency equates to proportional reductions in emissions of $\mathrm{CO}_{2}$, the main contributor to global warming. The proliferation of SUVs as passenger cars may significantly increase overall fuel consumption and therefore the greenhouse gas emissions). Advanced diesel engine technology could help offset this trend. Increasingly stringent air pollution standards and heightened awareness of the need for energy-efficient engines are spurring renewed diesel engine research. DOE's goal is to develop "clean" diesel engines for light trucks that are $35 \%$ more efficient than current gasoline engines and to improve the thermal efficiency of heavy diesel engines for large trucks (Classes 7 and 8 ) to $55 \%$.

\section{The DOE Role}

DOE's Office of Heavy Vehicle Technologies (OHVT) is focusing its research in cooperation with industry partners on developing diesel engine technologies that can realize large fuel savings. Major diesel engine program milestones include the following.

Develop by 2002 enabling technologies to support large-scale industry dieselization of light trucks.

Develop by 2004 enabling technologies for class $7-8$ trucks with fuel efficiency of $10 \mathrm{mpg}$ that meet prevailing emission standards.

Develop by 2006 diesel engines with fuel flexibility and thermal efficiency of $50 \%$ with diesel liquid alternative fuels

- By 2005, develop advanced powertrain technology for medium/heavy-duty trucks that achieves up to two times today's fuel economy, also incorporating an alternative fuels use capability.

- DOE has contributed to a number of technological accomplishments relating to the development and deployment of cleaner and more efficient diesel engines:

- New prototypes of diesel engines for sport utility vehicles have been built and are undergoing evaluation in test cells as well as in vehicles. Fuel economy is expected to be more than $50 \%$ better than gasoline engines.

- The program has helped engine manufacturers to reduce $\mathrm{NO}_{\mathrm{X}}$ emissions by over $50 \%$ and particulate matter by over $80 \%$ in production engines without after-treatment. New conceptual models of $\mathrm{NO}_{\mathrm{x}}$ production during diesel combustion developed by DOE national laboratories are now used by industry. 
- A new type of particulate filter has been developed through the prototype stage that removes over $80 \%$ of particulate emissions. Additionally, $\mathrm{NO}_{\mathrm{x}}$ catalysts have produced a greater than $50 \%$ reduction of $\mathrm{NO}_{x}$ while plasma-assisted devices have exceeded $70 \%$ on a small scale.

- Engine efficiency of approximately $52 \%$ has been achieved in test engines, compared to $44 \%$ in production engines when the program began and $46 \%$ today.

- Alternative-fuel heavy-duty engines have been introduced and certified in numerous applications. These include natural gas engines for urban buses and alcohol-fueled engines for trucks and buses.

- LNG-powered trucks with $80 \%$ less $\mathrm{NO}_{x}$ and particulates than conventional diesel-powered vehicles have been demonstrated.

- A multi-cylinder heavy-duty diesel engine that runs interchangeably on M85 and diesel fuel has been developed and demonstrated.

\section{Benefits and Costs}

Benefits. Successful implementation of the OHVT 1998 program plan is key to "turning the corner" regarding the growth in truck-related fuel consumption. It is expected to reduce petroleum consumption of all classes of trucks by .1 million barrels of oil per day by 2010 and .2 million barrels of oil per day by 2020 , amounting to a reduction of total highway petroleum consumption (including passenger cars) of $13.2 \%$ and $18.6 \%$ respectively. The reduction in projected petroleum use due to efficiency gains alone is estimated to be 552,000 barrels per day by 2020 , which is $8 \%$ of total highway petroleum use. This saving increases to 770,000 barrels per day by 2030 . Petroleum use reductions due to market penetration of non-petroleum fuels are estimated to be 807,000 barrels per day by 2020 and 1.06 million barrels per day by 2030. From 1983 to 1998, increased efficiency in heavy diesel trucks reduced emissions of carbon by 38.2 million metric tons and saving 16 billion gallons of fuel, the equivalent of 2.18 quadrillion Btu. The cumulative economic value of increased efficiency is estimated at about $\$ 17$ billion.

Increased Efficiency in Heavy Diesel Trucks

\begin{tabular}{|c|c|c|c|}
\hline $\begin{array}{c}\text { Gallons Saved } \\
\text { (millions) }\end{array}$ & Time Frame & $\begin{array}{c}\text { Btus Saved } \\
\text { (Quadrillions) }\end{array}$ & $\begin{array}{c}\text { Million Metric Tons } \\
\text { Carbon Reducued }\end{array}$ \\
\hline 15,725 & $1983-1998$ & 2.18 & 38.2 \\
\hline
\end{tabular}

Costs. Reducing the pollution from diesel engines will require significant investments in new technology and in fuel reformulations. The DOE R\&D investment in diesel engines from 1983 through FY 1997 totaled approximately $\$ 45$ million.

\section{The Big Picture}

The health and continued growth of the U.S. truck economy depends on enhancing diesel fuel efficiencies and, therefore, profitability of the trucking economy. Class $1-8$ trucks are the mainstay of U.S. trade, domestic commerce, and sustainable economic growth. Total highway freight transportation expenditures in 1995 were over $\$ 348$ billion, accounting for $79 \%$ of the U.S. freight bill and about $4.8 \%$ of the GDP.

\section{References}

U.S. Department of Energy, Office of Heavy Vehicle Technologies and Heavy Industry Partners, Multiyear Program Plan for 1998-2002, August 1998 (DOE-ORO/2071). 


\section{Parabolic Troughs: Solar Power for Today}

The lowest-cost solar power option available today is parabolic trough technology. These systems use curved mirrors to focus sunlight on a receiver pipe, heating the oil within it, producing steam and generating electricity. Parabolic-trough technology developed by DOE is being used in nine power plants known as the Solar Electric Generating Systems (SEGS) located in California's Mojave Desert. The plants have been operated as commercial peak power facilities since 1985 and sell their power to the local utility, Southern California Edison. The nine plants, which total 354 MW of installed capacity, generate enough power to meet the needs of approximately 500,000 people.

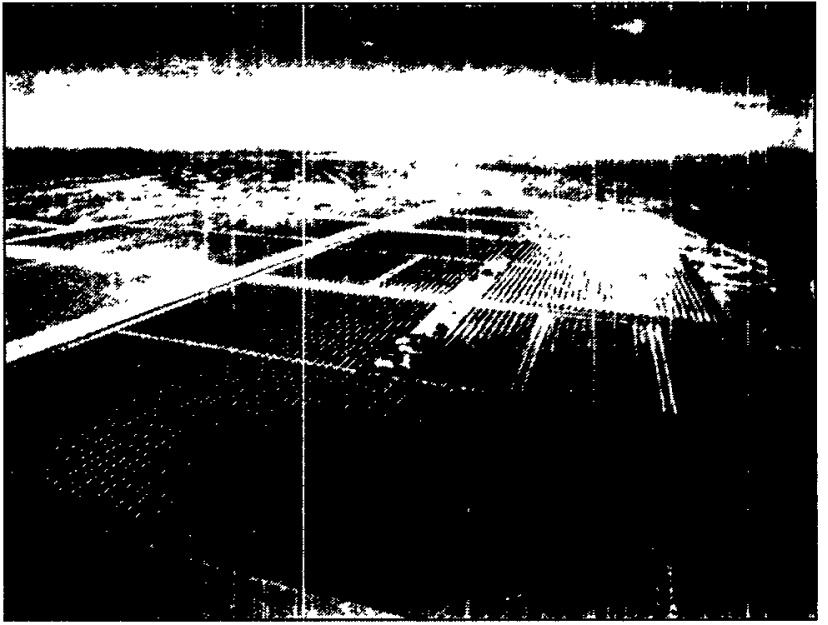

Aerial view of Kramer Junction in California

\section{Benefits, Costs, and the DOE Role}

In 1992, DOE and Sandia National Laboratories initiated an operation and maintenance (O\&M) costreduction study with KJC Operating Company (Kramer Junction), the operator of the SEGS III-VII plants. Through this six-year, $\$ 6.3$ Million R\&D effort (50/50 cost share), Kramer Junction and Sandia continued to advance parabolic-trough technology and helped reduce the O\&M costs of these facilities by $\$ 4$ million annually and $\$ 42$ million $(30 \%)$ during the remaining life of these projects. More impressively, the performance of the Kramer Junction plants has continued to improve over the last seven years. These five plants produced a record amount of solar electricity during 1998, with only average solar radiation. The figure below shows how the solar-to-electric efficiency of one plant (SEGS VI) has continued to improve over time. As these lessons begin to trickle down to the other SEGS facilities, their performance will improve as well.

Current O\&M activities are centered on the evacuated receiver tube located at the focus of the parabola-shaped mirrors. Since these tubes are expensive, DOE and SunLab are working with the existing trough facilities to improve their durability. SunLab is a virtual laboratory integrating the concentrating solar power program efforts conducted by both Sandia and the National Renewable Energy Laboratory.

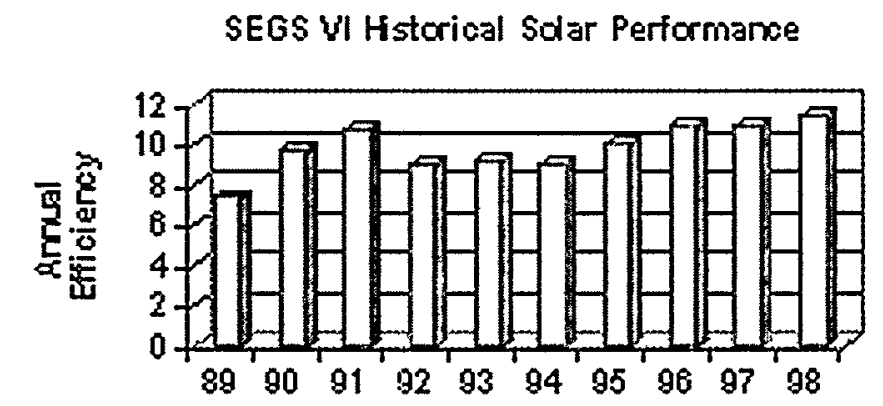
During 1998, SunLab assisted Daggett Leasing (the operator of SEGS I and II) in developing a low-cost replacement receiver tube that will dramatically improve the performance of the SEGS II plant, with a payback of less than two years. This effort continued in 1999, leading to similar solutions for the SEGS I plant, which has an earliergeneration collector with different design issues. DOE/SunLab also has plans to work with Harper Lake (the operator of SEGS VIII and IX plants) to allow them to take advantage of these technology improvements. 
The figure below charts the actual reduction in levelized energy cost (LEC) resulting from DOE's O\&M cost-reduction program in the early $1990 \mathrm{~s}$, from the projected reduction from DOE's new advancedtrough RD\&D (research, development, and deployment) initiative, and from the future implementation of

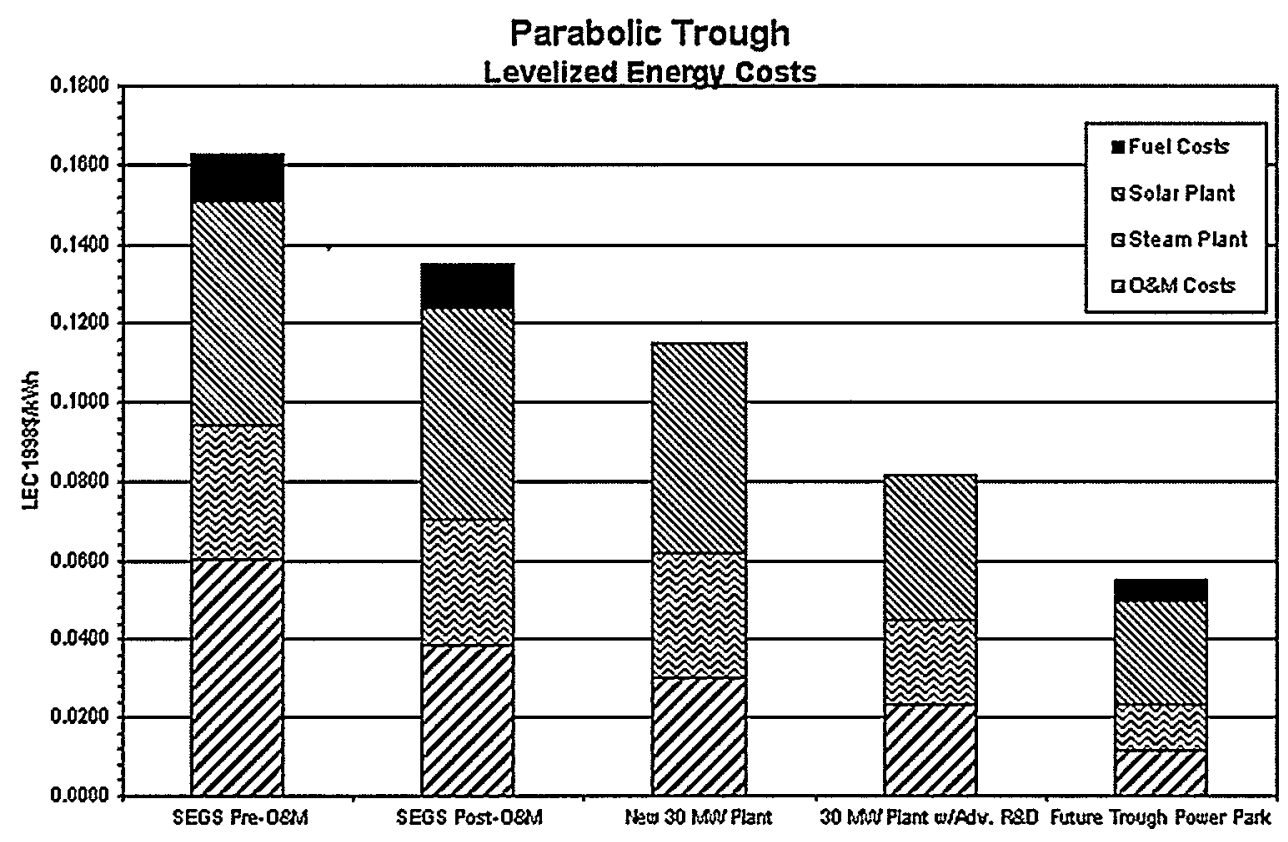

troughs in a solar-power-park configuration.

SEGS Pre-O\&M (1992) - Actual SEGS VI plant performance and O\&M costs before the $\mathrm{DOE} /$ Sandia/KJC O\&M cost-reduction program. The SEGS plants use $25 \%$ natural gas (fuel cost).

SEGS Post-O\&M (1998) - Shows the benefit of DOE's O\&M cost reduction program to SEGS VI. This includes performance improvements and O\&M cost reductions.

New 30 MW Plant (2000) - The next trough plant is likely to be an ISCCS (integrated solar combined cycle system). In this case, the costs shown are only for the solar power. In these plants, the cost of solar power is higher than the averaged power cost.

30-MW Plant with Advanced R\&D (2005) - An ISCCS plant reflecting the benefits of the trough activities during the next few years, primarily through enhanced performance and further cost reductions.

Future Trough Power Park (2010) - This is a large 200-MW SEGS plant built in a power park configuration. The cost reductions are primarily a result of building multiple (e.g., five) large plants. This scenario also assumes a production tax credit similar to REPI.

\section{For More Information}

DOE's SunLab web site: http://www.eren.doe.gov/sunlab

Price, H. W., and D. W. Kearney, "Parabolic Trough Technology Roadmap," NREL, January 1999.

Cable, R. G., G. E. Cohen, and D. W. Kearney, "SEGS Plant Performance 1989-1997," Proceeding of the ASME 1998 International Solar Energy Conference, Albuquerque, New Mexico, June 1998. 


\section{Wind Turbine Advances}

The fastest growing source of energy in the world during the 1990 s is the same source that has been used for centuries to fulfill a variety of needs-wind. New wind-generating capacity grew by $2100 \mathrm{MW}$ in 1998 , resulting in a $25 \%$ increase in worldwide wind-generating capacity to nearly $10,000 \mathrm{MW}$. The renewed popularity of this universal and inexhaustible resource has been made possible by dramatic improvements in wind turbine technology over the last decade. Most of the new capacity is provided by "wind plants" featuring from one to over one hundred modern, high-tech wind turbines towering 30 to 70 meters above the ground, with blades sweeping out circles 40 meters or more across. Wind is also being put to use with smaller turbines in a wide range of applications.

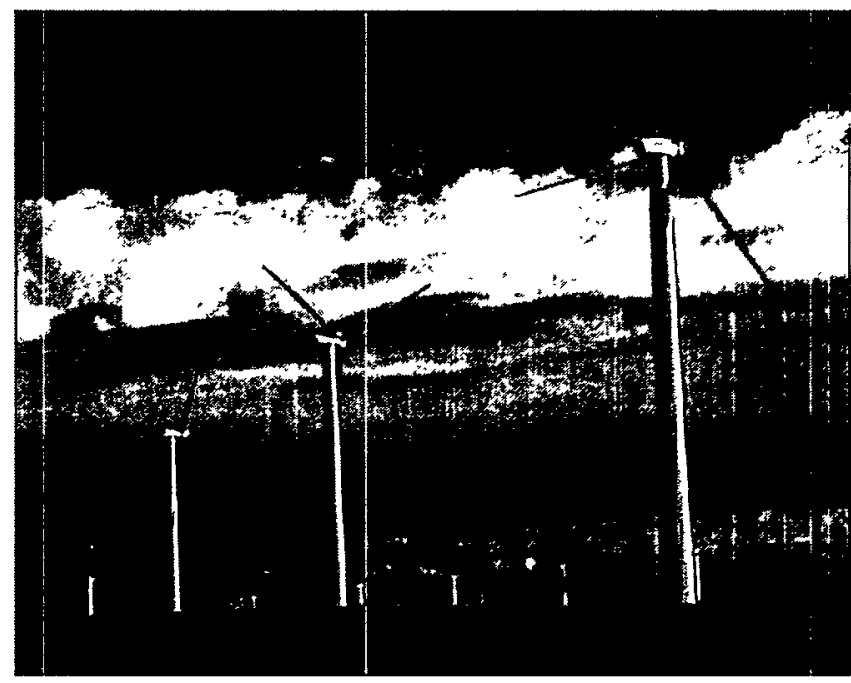

Wind plant near Lake Benton, Minnesota

\section{The DOE Role}

Government-sponsored R\&D in the United States and Europe has been key to helping the wind industry improve their technology. DOE is continuing to play a leading role in research that has yielded the sophisticated tools and expertise needed to design, build, and operate cost-competitive wind turbines. Further, DOE has helped U.S. industry put research breakthroughs to work through cost-shared partnerships that have produced world-class wind turbines.

\section{Benefits and Costs}

The 107-MW wind power plant shown above, located near Lake Benton, Minnesota, was the world's largest wind-generation facility at the time of its completion in 1998 by Enron Wind Corporation of Tehachapi, California. Electricity generated by this facility is sufficient to power 43,000 homes. Displacement of greenhouse gas emissions by this facility will be equivalent to removing 50,000 new cars and light trucks from the road. U.S. facilities totaling over $160 \mathrm{MW}$ in generating capacity are using Enron Wind's $750-\mathrm{kW}$ and $550-\mathrm{kW}$ turbines

"The DOE Wind Program has been extremely helpful in accelerating our development of commercial wind turbines through advanced airfoils, blade testing, design codes, turbine load verification, assistance with value engineering, and much more."

Kenneth C. Karas

Chairman \& Chief Executive Officer Enron Wind Corp.

and have generated $122 \mathrm{GWh}$ of electricity (equivalent to 1.3 trillion Btu of primary energy). Over their lifetimes, the turbines will displace 110 trillion Btu of primary energy, save $\$ 246$ million in energy costs, and reduce carbon emissions by 2.1 million metric tons. Enron Wind is currently underway in developing additional U.S. wind plants totaling over $300 \mathrm{MW}$ in generating capacity.

Enron Wind's turbine manufacturing subsidiary, Zond Energy Systems Inc. of Tehachapi, California, was competitively selected to partner with DOE under its wind turbine research and field verification 
programs for the development of the $550-\mathrm{kW} \mathrm{Z-40,} \mathrm{Zond's} \mathrm{first} \mathrm{commercial} \mathrm{wind} \mathrm{turbine} \mathrm{and} \mathrm{the}$ predecessor to their $750-\mathrm{kW}$ turbine. Under these programs, DOE was able to assist Zond with the latest wind turbine design methods and tools, provide blade structural and other testing services otherwise unavailable, and provide opportunities for Zond to gain valuable early field verification experience. The DOE contributions to the programs that supported Zond's $750-\mathrm{kW}$ turbine since 1994 total nearly $\$ 12$ million.

DOE has also partnered with Atlantic Orient Corporation of Norwich, Vermont, for the R\&D leading to their AOC 15/50 turbine, rated at $50 \mathrm{~kW}$. The AOC 15/50 is designed to be cost effective, rugged, and simple, at a size needed to serve a wide range of applications, from hybrid power systems for remote communities to grid-connected distributed power. Three of these turbines have been helping the utility serving Kotzebue, Alaska, reduce fuel consumption in their diesel power system since 1997, and installation of another seven turbines is planned for 1999. Other units are in operation in the extreme heat of the desert environment in Morocco. Atlantic Orient Corporation is now moving aggressively to supply orders for 30 more turbines over the next year.

\section{Future Developments}

Even more advanced technology is on the way for the future. DOE is currently sponsoring a $\$ 50$ million program to push the technology envelope further and develop the next generation of wind turbines, with $30 \%$ of these funds coming from private industry. These innovative, advanced turbines are targeted to produce electricity for $2.5 \mathrm{cents} / \mathrm{kWh}$ at good wind sites, which will make wind energy even more competitive with fossil generation sources in many locations around the world.

\section{For More Information}

DOE's Wind web site: http://www.eren.doe.gov/wind 


\section{Geothermal Heat Pumps}

Geothermal heat pumps (GHPs) use the Earth to meet residential and commercial heating, cooling and hot water needs. The temperature of the Earth's crust is extremely stable just a few feet below the surface. Even extreme cold spells and extended summer heat waves have little effect on the ground's temperature three or four feet down. This temperature stability is the principle behind GHP technology. GHPs discharge waste heat to the ground during the cooling season and extract heat from the ground during the heating season.

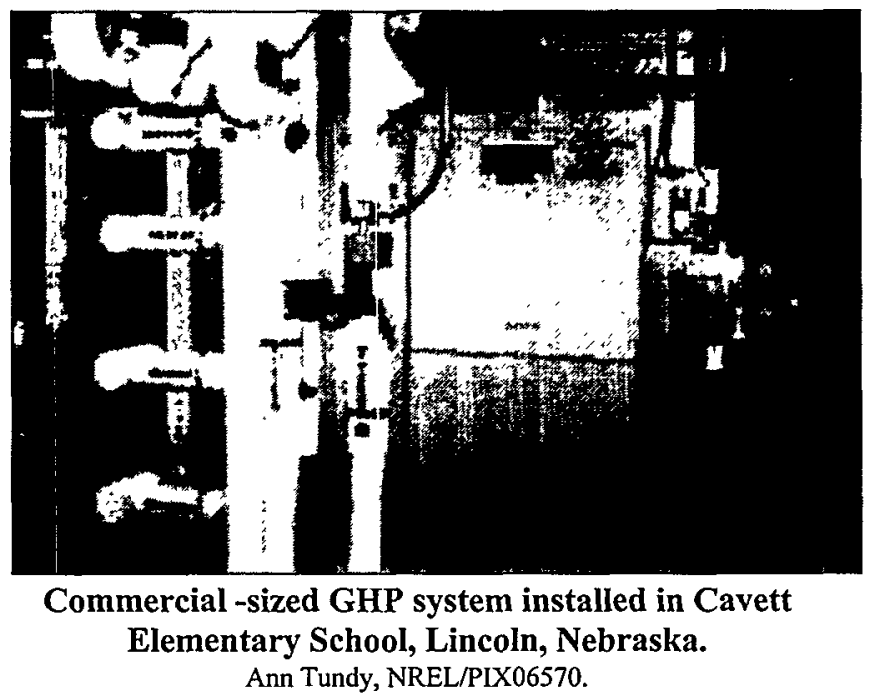

The DOE Role

During the 1980s Oak Ridge National Laboratory and the International Ground Source Heat Pump Association (IGSHPA) conducted experimental and analytical studies of GHP systems for DOE. The primary focus of the effort was to develop a technology base to enable the design of systems with lower first costs to the consumer. In 1994, as part of the Climate Change Action Plan, DOE worked with the Edison Electric Institute, EPA, Electric Power Research Institute (EPRI), IGSHPA, National Rural Electric Cooperative Association, and industry to create the Geothermal Heat Pump Consortium. DOE has also supported research and development activities, especially through IGSHPA, the American Society of Heating, Refrigeration, and Air-Conditioning Engineers, the National Ground Water Association, and DOE's national laboratories. The work has targeted several areas of GHP technology, including improving on-site thermal conductivity testing, improving grouts, lowering the cost of ground heat exchangers, and developing advanced design software to determine appropriate sizing of GHP systems.

\section{Benefits and Costs}

Geothermal heat pumps are one of the most cost-effective heating and cooling systems available. A typical system can reduce energy consumption by 23 to $44 \%$ compared to traditional heating/cooling systems according to EPA. While GHPs are typically more expensive to install, their greater efficiency means the investment may be recouped in three to ten years. Experience has shown that use of GHPs can be beneficial to electric utilities and their customers. GHPs offer a flatter load profile (reduced "peaks and valleys") because they take advantage of the Earth's relatively constant ground temperature. The result is a smaller contribution to weather-related peak demand than other with electric options.

A highly successful shared energy savings project at Fort Polk, Louisiana, where 4,000 U.S. Army housing units were converted to GHPs, is a splendid example of this technology's electric utility benefits through load management. Statistically valid data indicated that Fort Polk achieved a reduction of $43 \%$, or 7.5 MW, of peak summer load after installing GHPs and improved whole-house load factors from 0.52 to 0.62 . Since the GHP systems were installed, service calls on hot summer days have dropped from 90 
per day to just a few, testifying to the reliability of GHP systems. In February 1999 FEMP announced the selection of five contractors under the GHP-technology-specific super energy savings performance contracts to greatly increase private-sector investment and fund the installation of about 100,000 GHP units throughout the federal government.

About 340,000 GHPs are being used for heating and cooling of residential, commercial, and institutional buildings throughout the United States today. Assuming average unit annual savings of $\$ 300$ to $\$ 400$, annual savings due to displacement of air-source heat pumps and other conventional equipment by GHPs is between $\$ 100$ million and $\$ 140$ million per year. Savings from GHP units intalled between 1995 and 1998 are estimated to be $\$ 29-\$ 39$ million. Over their lifetimes, the units will save 25 trillion Btu of energy, $\$ 980$ million in energy costs, and reduce carbon emissions by 1.7 million metric tons. DOE funding for the GHP program has been approximately \$24 million from 1995 to 1998, with another \$35 million contributed by utilities.

\section{For More Information}

DOE's Geothermal web site: http://www.eren.doe.gov/geothermal. 


\section{Transpired Solar Collectors}

Most industrial and commercial buildings require large quantities of ventilation air to maintain a healthful work environment. In many regions, this ventilation air needs to be heated throughout the fall and winter. Transpired solar collectors are a reliable, lowcost technology for preheating ventilation air. With simple payback periods from 3 to 12 years and an estimated 30-year life span, transpired collector systems offer building owners substantial savings.

In a typical application, a large portion of a building's south-facing wall is clad with dark-colored, perforated metal sheeting, which performs as a large solar collector. The sheeting is mounted to the building's

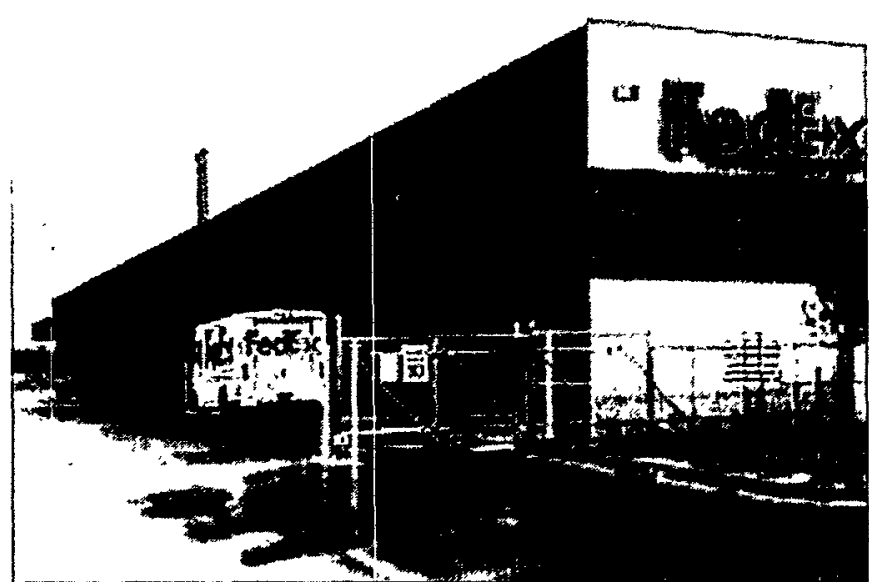

Transpired collector that is reducing conventional heating loads at a Denver-area Federal Express facility. Keith Gawlik, NREL/PIX04118 structural wall, creating a 4- to 6-inch gap between the two. As outside air is drawn through the collector's perforations by ventilation fans, its temperature increases by as much as $40^{\circ} \mathrm{F}$. The heated air flows to the top of the wall, where it is distributed to the building's interior through conventional ductwork.

\section{The DOE Role}

Scientists at DOE's National Renewable Energy Laboratory (NREL) and engineers at Conserval Systems, Inc. independently developed the transpired collector concept in the late $1980 \mathrm{~s}$. With funding from DOE, NREL researchers conducted fundamental investigations into the collector's heat-flow characteristics and developed TCFLOW, a computer program used by Conserval to determine optimal airflow rates, plenum depth, and perforation sizing and spacing. With funding from DOE's Inventions and Innovations Program, Conserval installed the technology in an assembly plant and monitored its use. Through its Commercialization Ventures Program, DOE is partially funding the construction of a new manufacturing facility in Buffalo, New York, after banks indicated that they would only partially finance the facility. DOE and NREL are also continuing to provide technical support to Conserval.

\section{Benefits and Costs}

The transpired solar collector was developed jointly during the last decade by researchers at NREL, engineers at Conserval, and the Department of Natural Resources, Canada, through a cost-shared collaborative in which DOE provided $\$ 2$ million in funding from 1990 to 1994 . As a result of these efforts, the transpired collector is one of the most efficient solar collectors, converting as much as $80 \%$ (60 to $75 \%$ under typical operating conditions) of the solar energy striking it into usable heat. Flat plate collectors for domestic hot water applications typically have efficiencies of 35-40\%. Conserval markets the technology as the Solarwall $\circledast$ and has installed more than 52 systems since 1992 . Ford, General Motors, Federal Express, and McDonnell Douglas are on the growing list of industrial users of this technology. A typical system (6237 $\mathrm{ft}^{2}$ of collector area) saves 1,665 million Btu per year. Current annual energy savings for the 52 installed systems is approximately 86,600 million Btu per year, saving 
about $\$ 400,000$ per year in avoided fuel costs, and reducing annual $\mathrm{CO}_{2}$ emissions by 10 million pounds. Over their lifetimes, the currently installed systems will displace 2.2 trillion Btus of energy, save $\$ 10$ million in avoided fuel costs, and reduce carbon emissions by 0.03 million metric tons.

Transpired collectors have caught the attention of the research community. In 1994 NREL and Conserval were jointly awarded R\&D Magazine's prestigious R\&D 100 Award for developing the technology, and Popular Science assessed the transpired collector as one of the 100 most important technology advances of 1994.

\section{Potential Future Benefits}

According to John Hollick, President of Conserval, "[transpired collectors have] the potential to be installed on the south wall of most new buildings and save enormous amounts of energy, which will help regions meet commitments to reduce emissions." Construction of the manufacturing plant in Buffalo could reduce installed costs by up to $40 \%$ with a 30 -day reduction in turn-around time.

For More Information

DOE's Solar Buildings web site: http://www.eren.doe.gov/solarbuildings 


\section{FIELD VERIFICATION, DEPLOYMENT, AND OUTREACH SUCCESSES}

Realizing the benefits of advanced technologies requires that they find their way into the marketplace so they can be used by consumers. Market forces determine which technologies make this transition to the market; however, major informational, financial, institutional, and infrastructure barriers must often be overcome in order for clean energy technologies to become a part of our over-all energy system.

The market of energy users is broad and diverse, including hundreds of millions of residential, commercial, and transportation users, hundreds of thousands of industrial users and millions of users in the power sector. To enable deployment of advanced energy technologies and practices, EERE works with the leadership of high leverage public and private organizations, such as States, universities, associations, unions, technology companies, utilities, and civic/community groups who have the direct constituencies, markets, and resources that can influence energy decisions.

In addition, DOE provides financial assistance and works with public- and private-sector officials to identify and remove barriers in government procurement systems, design and construction practices, financing practices, insurance practices, and in codes and standards.

\section{A SAMPLE OF VERIFICATION, DEPLOYMENT, AND OUTREACH SUCCESSES}

This section describes nine field verification, deployment, and outreach successes that have accelerated and expanded the use of efficient and renewable energy technologies.

A Sample of Field Verification, Deployment, and Outreach Successes

\begin{tabular}{|l|l|}
\hline \multicolumn{1}{|c|}{ Buildings } & \multicolumn{1}{|c|}{ Federal } \\
\hline$>$ Weatherization Assistance Program & $>$ Energy Savings Performance Contracts \\
\hline$>$ Building Standards & \\
\hline$>$ Rebuild America & \multicolumn{1}{|c|}{ Industry } \\
\hline \multicolumn{1}{|c|}{ Transportation } \\
\hline Steel's Burns Harbor Division \\
\hline Industrial Assessment Centers & $>$ Cellulose-to-Ethanol Program \\
\hline$>$ Motor Challenge & \\
\hline
\end{tabular}




\section{Weatherization Assistance Program}

DOE's Weatherization Assistance Program has long served as the nation's core program for delivering energy conservation services to low-income Americans. Low-income households spend about $14.9 \%$ of their income for energy needs, as opposed to the 3.5\% of income spent on energy needs by other households. The Weatherization Program reduces this disproportionate burden. The program's resources are focused particularly on the elderly, persons with disabilities, and families with children.

The Weatherization Program is implemented through grants to State Weatherization Offices in all 50 states. These agencies allocate funds to about 950 local agencies, most of which are private, nonprofit community action agencies. Through these local agencies, the program has retrofitted 4.8 million homes since 1976. It is estimated that the average home weatherized in 1998 will save 32.2 million Btu of energy annually, and occupants will pay about $\$ 200$ less in utility bills each year.

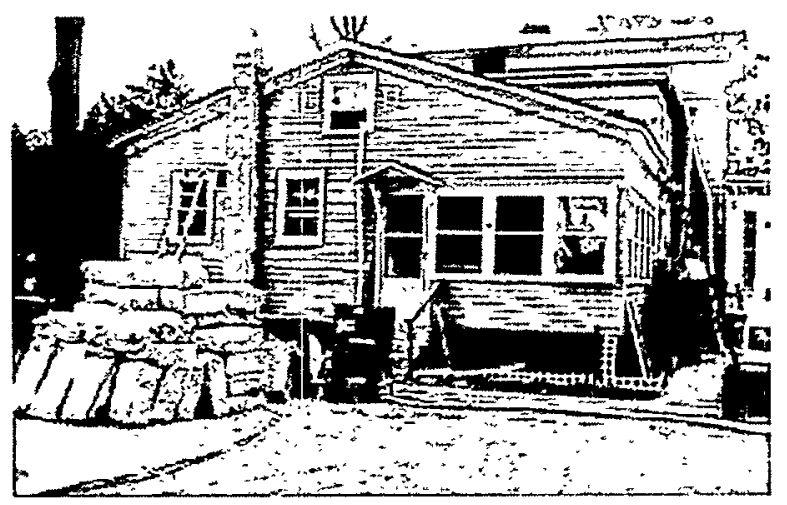

Powerful blowing machines make the job of installing cellulose insulation more efficient.

\section{The DOE Role}

The Weatherization Program has served as the nation's core program for delivering energy conservation services to low-income Americans since it was created by Congress in 1976 under the Energy Conservation and Production Act. DOE funding is supplemented by state allocations of funding from the Low-Income Home Energy Assistance Program (LIHEAP-sponsored by the Department of Health and Human Services) and by resources leveraged from utilities, states, and other sources. The program is managed by the DOE Office of Building Technology, State and Community Programs. As the result of successful leveraging, DOE provided less than half $(45 \%)$ of the resources spent on low-income weatherization between 1978 and 1996; the vast majority of those non-DOE funds are channeled through the program and are spent according to DOE's program rules.

The Weatherization Program grew out of the 1973 oil crisis, when state and community agencies began helping families conserve energy and save money, in many cases to keep them from having to choose between food and fuel. The program initially emphasized emergency and temporary measures such as caulking and weather stripping. By the early 1980 s, the emphasis turned to more permanent and costeffective measures such as installing storm windows and insulating attics. Program funding for efficiency improvements to existing space heating and water heating systems and replacement of defective furnaces and boilers was first allowed in the mid-1980s. Regulations adopted in the 1990s ensured further energy and cost savings by extending the program to cooling technologies in warm climates, where cooling costs are higher than heating costs.

Since the early 1990 s, the program has been further improved by better training, better management practices, and various technical advances, with little increase in cost. DOE funding has enabled Oak Ridge National Laboratory to develop the National Energy Audit (NEAT), which selects cost-effective energy conservation measures specifically for each house. NEAT is currently being used by approximately 500 local agencies in 31 states to make retrofitting decisions for more than 80,000 lowincome dwellings every year. 


\section{Benefits and Costs}

A 1990 evaluation of the Weatherization Program found that the program was meeting the objectives of its enabling legislation by (1) saving energy, (2) lowering fuel bills, and (3) improving the health and safety of low-income households. Installation of energy conservation measures, including overhead and management, cost an average of $\$ 1550$ per house. The annual energy savings for a home weatherized in 1989 was estimated to be 17.6 million Btu, producing an energy savings of $\$ 1690$ over the 20 -year lifetime of the weatherization measures. For homes heated with natural gas, weatherization reduced natural gas consumption for space heating by $18.3 \%$.

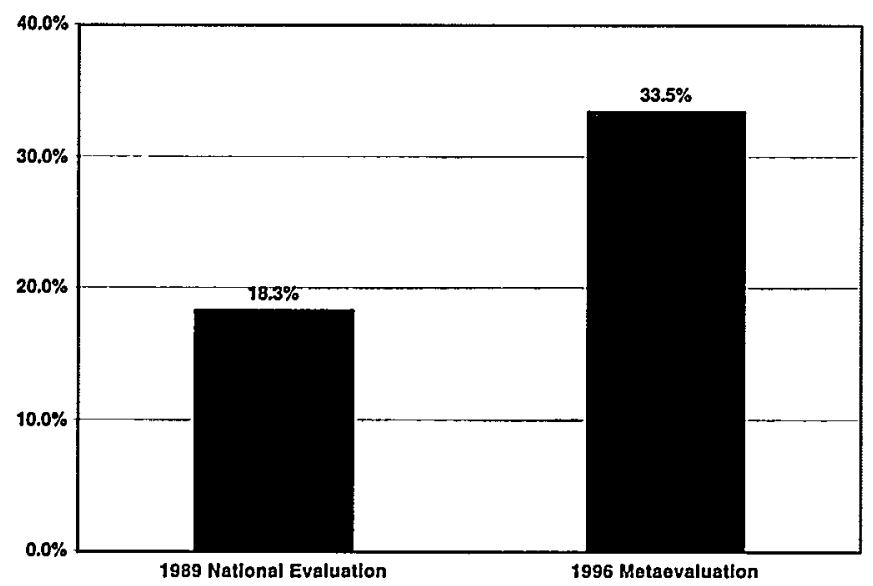

By 1996 program costs rose $12 \%$ with inflation adjustments to $\$ 1700$ per home, but the p'rogram was achieving $80 \%$ higher average savings per dwelling than in 1989 , according to a 1996 metaevaluation of 17 state-level evaluations. The study suggested that improving program practices between 1989 and 1996 increased average savings to $33.5 \%$ of natural gas space heating consumption. Assuming that this same level of improvement was achieved in homes heated by other fuels, the annual energy savings for a home weatherized in 1996 is estimated to be 32.2 million Btu. Over the 20 -year life of the weatherization measures, this represents an energy cost savings of more than $\$ 3000$ per house.

Weatherization of low-income homes directly and immediately improves the health and safety of inhabitants by reducing carbon monoxide emissions and eliminating fire hazards, in addition to lightening the financial burdens of those most in need. The program's longer-term impacts include community revitalization. The Weatherization Program has also created about 8,000 jobs nationwide; 52 jobs grow directly from every million dollars invested in the program.

DOE's 1998 budget of $\$ 125$ million leveraged an additional $\$ 198$ million to weatherize 167,400 homes. Over the 20-year life of the weatherization measures, these homes will save 108 trillion Btu of energy, their occupants will pay $\$ 550$ million less in utility bills, and 1.63 MMTC of carbon emissions will be averted.

\section{The Big Picture}

The Weatherization Program is accomplishing its primary mission by providing a program that significantly decreases energy use in low-income homes. Although five million homes have been weatherized since the program's inception, the largest part of the task still remains. Nearly 28 million households are federally eligible for weatherization assistance.

\section{For More Information}

http://www.eren.doe.gov/buildings/state_and_community/weather/

Berry, Linda G., Marilyn A. Brown, and Laurence F. Kinney, Progress Report of the National Weatherization Assistance Program, Oak Ridge National Laboratory, Report ORNL/CON-450, 1997. 


\section{Building Standards}

States with energy codes require that all new houses and new commercial, industrial, and high-rise residential buildings achieve at least a minimum level of energy efficiency that is cost-effective and technically feasible. Since 1980, DOE's Building Standards and Guidelines Program (BSGP) has worked with a variety of partners to improve the design and implementation of these codes. BSGP provides information and a comprehensive line of support tools to help builders, designers, and code officials to comply with energy codes.

\section{The DOE Role}

The Building Standards and Guidelines Program takes a comprehensive approach and works with a wide range of organizations to achieve its goals. Collaborators include DOE Regional Offices, state energy agencies, model code and standards organizations, public interest groups, and a variety of industrial partners. DOE, in collaboration with these partners, has accelerated the implementation of building codes in many states by providing technical support, DOE State Energy Program grants, and other BSGP services such as an information hotline, a web site, national building codes conferences, and a newsletter.

Through its outreach activities, DOE has provided direct technical support in the form of training, software development, analysis and research, advocacy, and materials development to 42 states and has created qualified energy code instructors in 32 states. Since 1994, BSGP has responded to over 12,000 support calls from code users and distributed over 23,000 copies of code compliance materials.

DOE has produced and widely disseminated MECcheck ${ }^{\mathrm{TM}}$, a software tool released in 1994 to simplify and improve code compliance. MECcheck helps designers, builders, code officials, and others in the building industry to comply with the Model Energy Code (MEC) for residential buildings. MECcheck materials include a comprehensive set of support tools, which combine simplified code requirements, easy-to-use software, and a consolidated workbook with prescriptive compliance tables, plus videos and training materials.

BSGP sponsors MECcheck training classes and periodic train-the-trainer sessions. The National Association of Home Builders incorporated MECcheck into their MEC Manual in early 1996. Twelve states currently distribute MECcheck to their code users. DOE estimates that MECcheck is used by at least 35,000 builders and code officials.

DOE has provided extensive energy code training using a variety of methods, including delivery via satellite broadcast and computerbased training tools. More than 1,000 individuals have attended.

DOE-supported training courses, and more than 250 individuals have participated in a train-thetrainer program that focuses on developing qualified MECcheck and COMcheck trainers.

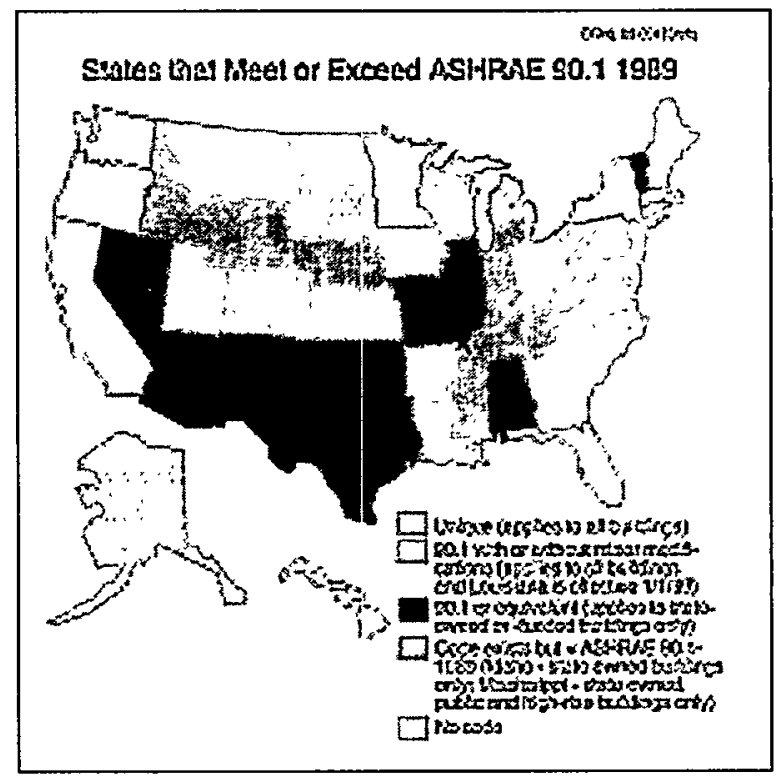




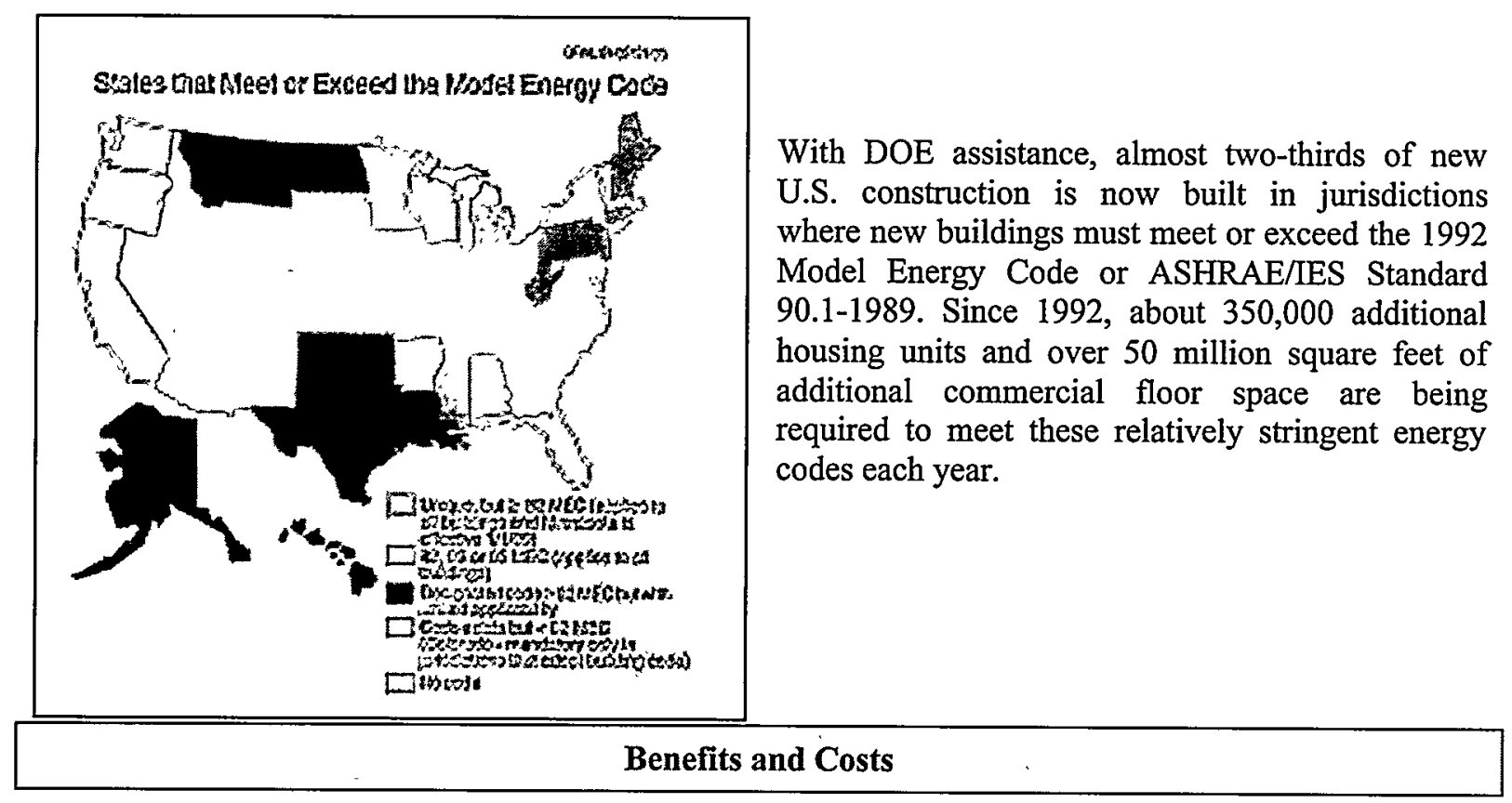

The benefits achieved from energy code upgrades through 1998 are shown in the following table. These savings are the result of energy code development, adoption, and support activities of DOE and its numerous private- and public-sector collaborators. The estimates are based on current adoption of state energy codes, and they assume that roughly half of the potential energy savings are actually realized. Thus, the estimates recognize that code compliance and enforcement are imperfect and that actual energy performance is not as energy-efficient as rated performance. Even with this conservative assumption, consumers nationwide saved around $\$ 1.1$ billion in 1998, equivalent to about $1 \%$ of total energy expenditures for space heating and cooling in all buildings, as a result of the adoption and implementation of improved energy codes. These savings are limited in part by the slow turnover of the nation's building stock. The savings will automatically grow over time as more buildings are constructed and more jurisdictions adopt state-of-the-art codes.

\begin{tabular}{ll} 
Benefits of Residential and Commercial Building Energy Codes in 1998 \\
\hline Primary Energy Savings & $154 \mathrm{TBtu}$ \\
Energy Cost Savings & $\$ 1.12 \mathrm{~B}(1994 \$)$ \\
Carbon Reductions & $3.55 \mathrm{MtC}$ \\
\hline
\end{tabular}

The BSGP has operated since 1980. The program's budget in 1998 was $\$ 8$ million per year. Assuming steady funding from 1980 through 1998, the cumulative DOE investment has been $\$ 144$ million. Approximately half of this budget goes to state agencies through DOE's State Energy Program.

\section{For More Information}

http://www.energycodes.org/

Geller, Howard and Jennifer Thorne. 1999. "U.S. Department of Energy's Office of Building Technologies: Successful Initiatives of the 1990s." American Council for an Energy Efficient Economy: Washington, D.C. 


\section{Rebuild America: Catalyzing Community Networks}

DOE's Rebuild America program aims to accelerate the adoption of energy-efficient techniques and practices in commercial, institutional, and multi-family residential buildings. The network of over 250 community partnerships that it has created involves local governments, schools, housing agencies, and private businesses. Each partnership is unique; each has its own motivations (affordable energy, environmental quality, community development, job creation, or school improvement); and each community sets its own goals. Altogether, these partnerships are pursuing energy-efficient retrofits of more than 800 million square feet of commercial floorspace.

\section{The DOE Role}

The program supports the partnerships with a national network of technical and business experts, resource materials, and access to innovative solutions. Initial seed money for showcase partnerships is provided to allow continuing state involvement, and a program representative is assigned to coordinate technical assistance to the partnerships. This representative works with Rebuild America resources to teach communities about financing options and sources of technical expertise. These resources include guidebooks, technical experts, software, training and workshops, peer-to-peer exchange networks, and referrals to companion programs. By providing business and technical tools and customized assistance to partnerships, DOE leverages local resources to the benefit of America's communities. Rebuild America then promotes its partnerships and recognizes their leaders locally, regionally, and nationally.

Some partnerships have leveraged as much as $\$ 25$ million or more in private investment for their projects. They have also partnered with national financial institutions and federal empowerment/enterprise zones, used municipal bond issues, revolving loan programs, and historic preservation tax credits, and tapped commercial industry to fund projects. By 2003 , Rebuild America communities will have generated $\$ 3$ billion in private community investment and created 26,000 new jobs. Many Rebuild America partnerships have found that energy improvement in buildings can help them address other community needs, such as business development, economic revitalization, better education and housing, and resource conservation.

Partnerships' projects vary widely in size and scope, from simple lighting retrofits to statewide programs that include comprehensive building energy audits and retrofits and ongoing energy management and conservation programs. Building systems improvements can include energy-efficient lighting, heating and cooling equipment, windows, and ventilation systems, to name a few. Partnerships also get advice on energy audits, indoor air quality, renewable energy, building commissioning, performance contracting, measurement and verification, and other energy-related issues.

\section{Benefits and Costs}

Rebuild America is fostering community partnerships from rural Alaska to downtown Atlanta to Guam, with 33 state energy offices active in the program. Cities, counties, and states have initiated local partnerships with business owners, community leaders, utilities, school administrators, nonprofits, and economic development organizations to accomplish building renovation projects. With approximately over 250 partnerships having committed over 800 million square feet of building space for renovation, Rebuild America is well on its way to exceeding its goal for 2003: over 250 communities committing two billion square feet of floor space to energy retrofits. That means Rebuild America will save $\$ 650$ million dollars in energy costs per year and reduce air pollution by 1.6 million tons of carbon dioxide annually. At 


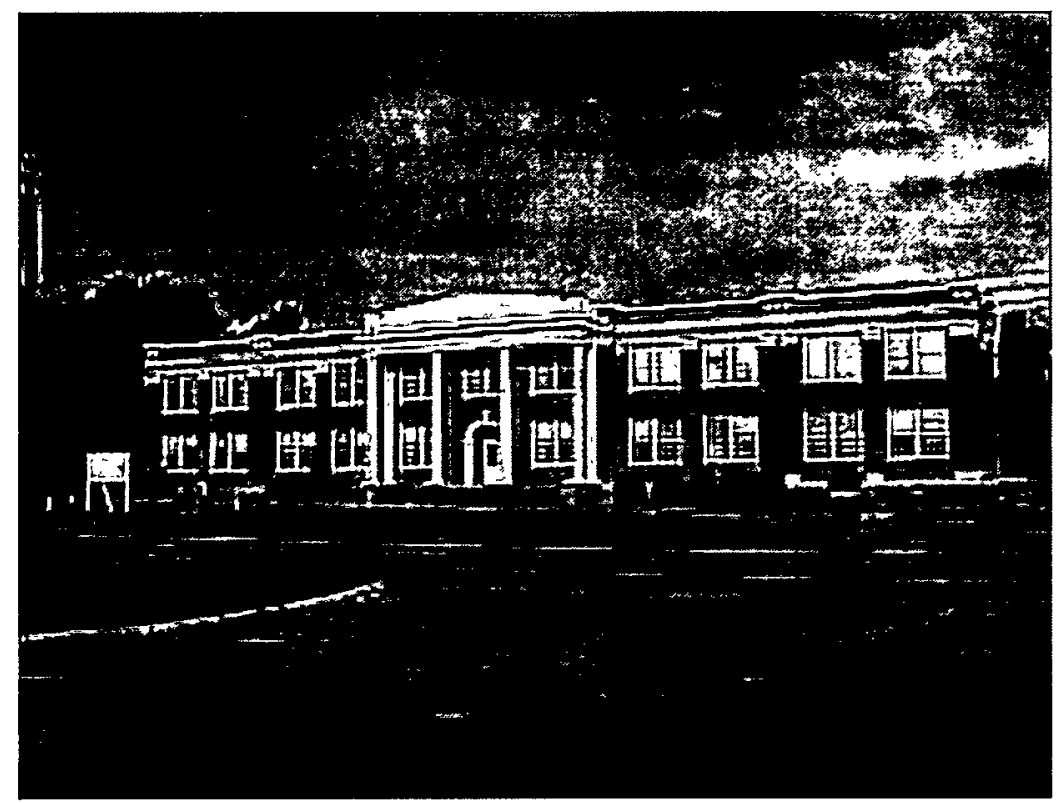

Rebuild America is benchmarking schools in Ohio and other states. one-fourth of its goal, estimates of benefits in 1999 are 32 trillion Btu of saved energy, $\$ 162$ million in energy cost savings, and 0.4 MMTC of carbon dioxide emission reductions.

Rebuild America partnerships are giving older buildings a new lease on life with new technology and are helping business people, universities, school districts, arts and cultural organizations, and public agencies save 20 to 30 percent on their energy bills. Partnerships are encouraged to set energy conservation goals of at least 25 percent. The money saved can be put to work back in the community - buying computers and books for schools, revitalizing decaying down-

towns, and protecting the environment.

Partnerships are now at work in 46 states, within several Native American tribes, and in two U.S. territories. For example:

- Building Owners and Managers of Atlanta, Inc., has targeted 30 million square feet of commercial office and retail space for renovation.

- The Portland Energy Office has completed retrofits on 35.8 million square feet.

- Rebuild Idaho has audited one million square feet in the Idaho Falls School District and saved one school $\$ 12,000$ in 10 days during a vacation shutdown demonstration in 1998. The total weathernormalized savings to date for the school district is $\$ 45,000$.

- Rebuild Webster City, Iowa, has retrofitted 20 buildings, including several schools, municipal buildings, churches, and private businesses, by leveraging a small amount of federal funding (less than $\$ 50,000$ ) into nearly $\$ 5$ million in energy efficiency improvements.

- Bob Housh, Project Director of EnergyWorks Rebuild America partnership in Kansas City, Missouri, estimates that his project has "identified over $\$ 2.5$ million in annual savings in about 6.5 million square feet of space."

DOE has invested about $\$ 7$ million in $R \& D$ and technical assistance through Rebuild America since the program's inception in 1995.

\section{For More Information}

http://www.eren.doe.gov/buildings/rebuild/ 


\section{Energy Savings Performance Contracts}

Energy savings performance contracts (ESPC) are a type of contract used by DOE and other federal agency energy management programs to cut government energy use and improve federal building energy efficiency. Authorized by the Energy Policy Act of 1992, ESPCs provide financing that is an alternative to federal appropriations. Federal agencies contract with private energy services companies to install and operate the innovative and energy efficient technologies and processes of the private sector with little upfront government money. As of 1998, 30 ESPC and Super ESPC projects were awarded by federal agencies. Currently, there is about $\$ 450$ million in potential projects under the Super ESPCs. Super ESPCS were put in place by 1999 that have a total contract authority of over $\$ 6$ billion. If the maximum authority of the contracts is used, the resulting contract value of the projects will reduce federal energy bills by $\$ 10$ billion over their lifetimes, providing the federal government with funds that can be used for other priorities. The projects will also reduce carbon emissions by 2.8 million metric tons, and avoid the emission of 28,000 metric tons of $\mathrm{NO}_{\mathrm{x}}$ and 49,000 metric tons of $\mathrm{SO}_{2}$.

\section{The DOE Role}

The DOE Federal Energy Management Program promotes alternative financing methods to implement energy efficiency and renewable and emerging technology projects through the use of ESPCs and regional and technology-specific Super ESPCs. FEMP's FY1999 budget allocated $\$ 8.2$ million to support the FEMP Service Network and to provide guidance and assistance to customers of ESPCs and other alternative financing such as utility energy services contracts.

FEMP actively promotes the use of ESPCs and Super ESPCs by placing information on its website, by providing TeleFEMP, broadcasts that detail the benefits of ESPCs, and through the national FEMP Service Network workshops and technical assistance. As part of the continuing evolution of the ESPC,

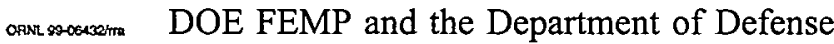

ESPCs Reallocate the Federal Customer's Payments for Energy and Energy-Related Operations \& Maintenance Expenses ( + O\&M) have recently simplified the ESPC process to make it more accessible to a wider range of

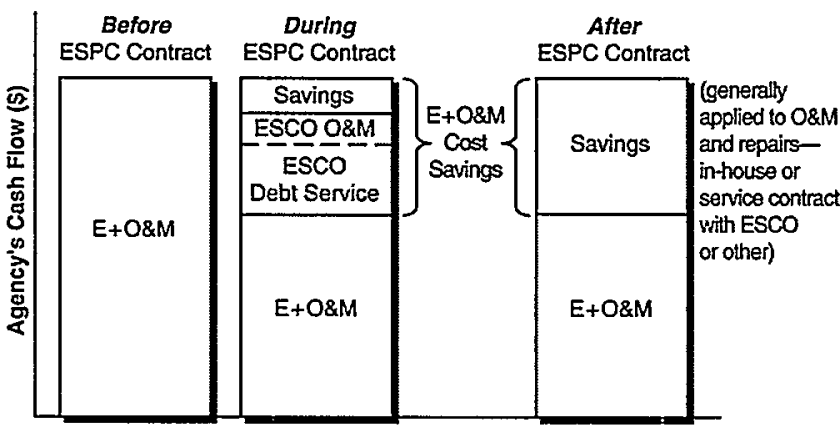
federal organizations.

In the ESPC process, an energy services company upgrades existing processes or installs new equipment. The contractor guarantees a fixed energy cost savings over the life of the contract and is paid directly from those cost savings. Federal agencies retain the remainder of the energy cost savings, for themselves. Currently, federal agencies receive, on average, $\$ 2$ in savings for every $\$ 1$ in contractor investments.

Super ESPCs simplify the process of implementing an energy services contract. Super ESPCs are regional or national agreements that the government has made with energy services companies who have competed for the contracts and demonstrated their experience and qualifications. Federal agencies can place delivery orders against these "indefinite-delivery, indefinite-quantity" agreements, customizing the agreement to their own site-specific requirements. This allows agencies to cut the time and effort required to implement an ESPC with an energy service company to complete the order at least in half. 


\section{Benefits and Costs}

One example of the benefits of ESPC agreements is in Hanford, Washington. One year after the Department of Energy's Richland Operations Office awarded an energy savings performance contract (ESPC) of unprecedented size, the department began two decades' worth of reduced energy consumption and more than $\$ 108$ million in savings. The Hanford ESPC was facilitated by guidance and monetary support from FEMP.

In March 1997, DOE's Richland Operations Office awarded energy services provider Johnson Controls a 25 -year, $\$ 160.3$ million contract to replace the two central heating plants with 42 state-of-the-art steam production units located at 28 sites across Hanford; install a fully automated system to control operation of the package boilers; upgrade the World War II-era steam distribution system; and redesign the HVAC system. Under the terms of the ESPC, the Department of Energy will realize annual savings of approximately $\$ 4.32$ million over 25 years.

Hanford's new, highly efficient boilers, fueled with natural gas and low-sulfur fuel oil, are designed to operate at efficiencies greater than $83 \%$, compared to the $33 \%$ efficiency of the old central heating plants, and to consume $30 \%$ less fuel. $\mathrm{NO}_{\mathrm{x}}$ and $\mathrm{SO}_{2}$ emissions will be cut by as much as $95 \%$, or 800 tons, per year and 5 million gallons of water will be conserved annually. Preliminary project validation efforts indicate that savings will range from 55 to $91 \%$ of the energy that would have otherwise been consumed-approximately 198 to 327.6 billion Btu.

Other examples of the significant benefits to be reaped from conventional ESPC and projects conducted under a Super ESPC are:

- In September 1998, the EPA's National Vehicle and Fuel Emissions Laboratory in Ann Arbor, Michigan, awarded an $\$ 8.5$ million ESPC to overhaul its facilities. Annual energy costs at the Laboratory will be slashed from $\$ 1.08$ million to approximately $\$ 368,000$, and its annual energy consumption levels will be cut by $66 \%$.

- On June 8, 1998, the initial Super ESPC delivery order was awarded for the U.S. Coast Guard for upgrades to its Integrated Support Center in Kodiak, Alaska. ERI Services, Inc., will invest $\$ 954,353$ in energy-efficiency measures. The government anticipates annual savings of $\$ 228,824$ and 662,000 kilowatt-hours over the seven-year delivery order term. Fuel oil consumption will also be cut by more than 135,000 gallons per year

- On February 22, 1999, the National Aeronautics and Space Administration utilized the Central Region Super ESPC to contract with Honeywell to install energy-efficient lights and compressed-air systems, reduce water consumption, and improve air conditioning controls at three facilities. The 23-year contract value of $\$ 43$ million is expected to provide NASA with energy and operational cost savings of approximately $\$ 2$ million per year.

\section{For More Information}

U.S. Department of Energy, Office of Energy Efficiency and Renewable Energy, Federal Energy Management Program, "Energy Savings Performance Contracting Overview," available at http://www.eren.doe.gov/femp/financing/espcoverview.html

U.S. Department of Energy, Office of Energy Efficiency and Renewable Energy, Federal Energy Management Program, FEMP Focus Newsletter, June 1997, available at http://www.eren.doe.gov/femp/newsevents/femp_focus/jun97_awards.html 


\section{Bethlehem Steel's Burns Harbor Division}

Bethlehem Steel Corporation recently joined with the Department of Energy's Office of Industrial Technologies to showcase energy saving technologies for the strategically important steel sector. To remain competitive in the global marketplace, U.S. steel producers must consistently reduce production costs while improving the quality of their products. A critical component of lowering overall production costs is reducing energy consumption during production.

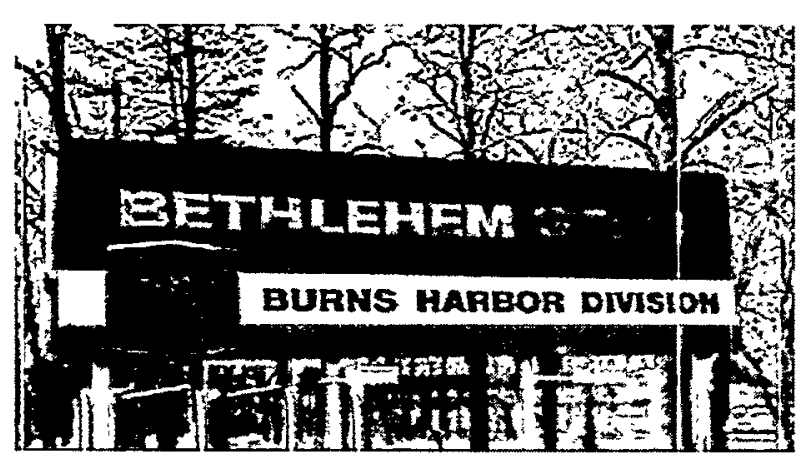

The focus of the co-funded Bethlehem Steel (BSC) and Office of Industrial Technology (OIT) partnership was to slash energy costs at BSC's Burns Harbor, Indiana, steel mill through application and installation of advanced process technologies. It is estimated that if the six technologies and processes implemented at Burns Harbor were implemented throughout the steel industry, net energy savings by 2005 will be over 93 trillion Btu per year, the equivalent of over $\$ 198$ million. In April 1998, steel industry decision-makers attended the DOE-organized Bethlehem Steel Energy Technology Showcase, which offered attendees an unusual opportunity to learn about these and other emerging steel technologies that can save energy, reduce emissions, and increase productivity.

\section{The DOE Role}

The Office of Industrial Technologies has been successful in lowering barriers to industry adoption of new processes and technologies by partnering with firms such as Bethlehem Steel Corporation. These partnerships demonstrate to other firms that the benefits of adoption outweigh the costs, and have allowed DOE to cost-share research and development of several of the innovative processes and technologies that were installed at Burns Harbor:

- Steam boiler system retrofits were conducted under the auspices of the Steam Challenge, a publicprivate partnership established by OIT and the Alliance to Save Energy.

- Optimization of induced draft fans in the basic oxygen furnaces (BOF) was part of an OIT Motor Challenge Showcase Demonstration.

- Installation of Sandusky International nickel aluminide steel rolls was made possible in part by nickel aluminide research funded by the OIT Advanced Industrial Materials Program.

- Installation of a Praxair oxy-fuel fired furnace combustion system was preceded by technology development funded by a grant from OIT's NICE3 Program.

- Adoption of the blast furnace granulated coal injection process was made possible by proof-ofconcept research funded by DOE's Clean Coal Technology Program.

- Galvanneal advanced temperature measurement sensors and an oscillation combustion system, R\&D funded in part by OIT's Industries of the Future Steel program.

\section{Benefits and Costs}

Financial and energy savings of $\$ 8$ million and 2 trillion Btu will be realized at Burns Harbor. This includes enhancements made to the facility's steam boiler system that resulted in annual saving of some 
40,000 megawatt-hours of electricity and 85 billion Btu of natural gas. Steel making at Burns Harbor requires large amounts of electricity that is produced by six steam turbines. To improve energy efficiency, the project focused on redesigning a turbine during scheduled maintenance periods, increasing the efficiency and electrical output under normal operations from 42 to 48 megawatts. Improving steam turbine performance at Burns Harbor resulted in first-year direct cost savings of $\$ 3.3$ million. The direct investment for the steam turbine technology upgrade was only $\$ 3.4$ million more than the cost of a standard maintenance overhaul.

Nickel aluminide steel rolls installed in the facility's annealing furnace save 300 billion Btu $(\$ 636,000)$ per ${ }^{4 M}$ year. The advanced material provides high strength and long life in hostile manufacturing environments, $3 \mathrm{M}$ decreasing downtime and saving energy.

Fans, combustion systems, and sensors were also instrumental in energy and cost savings. Optimization of BOF draft fans is saving 15,500 megawatt-hours per year, working out to annual cost savings of more than $\$ 620,100$ per year. The granulated coal injection process saves about 1.2 trillion Btu $(\$ 2,544,000)$

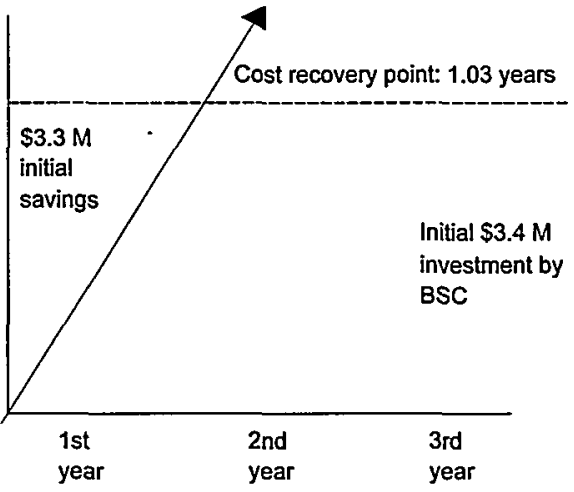
annually. Burns Harbor's new oscillating combustion system saves 260 billion Btu (\$551,200) per year and lowers $\mathrm{NO}_{\mathrm{x}}$ emissions, while the oxy-fuel-fired slab heating furnace combustion system saves 112 billion Btu $(\$ 237,440)$ per year. And the newly installed galvanneal temperature measurement sensor saves 100 billion Btu $(\$ 212,000)$ worth of energy per year.

\section{The Big Picture}

Assuming full market penetration of the technologies and processes demonstrated at the Burns Harbor Division, the domestic steel industry stands to reap net energy savings of 93.5 trillion Btu in 2005: 12.4 tBtu from the nickel aluminide steel rolls, $1.8 \mathrm{tBtu}$ from the basic oxygen furnaces (BOF) fans, $77 \mathrm{tBtu}$ from the Praxair oxy-fuel fired combustion system, $1.3 \mathrm{tBtu}$ from Galvanneal temperature measurement sensors, and $1 \mathrm{tBtu}$ from the oscillating combustion system. Energy cost savings of $\$ 198$ million would result.

In addition to financial costs savings resulting from greater energy efficiency, the performance improvements from just two of the technologies, the nickel aluminide steel rolls and the oxy-fuel fired combustion system, result in significant industry-wide annual emissions reductions: Carbon dioxide $\left(\mathrm{CO}_{2}\right)$ - 1.2 million tons $(297,818 \mathrm{MMTCE})$; Oxides of nitrogen $\left(\mathrm{NO}_{\mathrm{x}}\right)-4390$ tons; Sulfur oxides $\left(\mathrm{SO}_{\mathrm{x}}\right)$ 8100 tons; Volatile Organic Compounds (VOCs) - 47 tons.

\section{For More Information}

U.S. Department of Energy, Office of Energy Efficiency and Renewable Energy, OIT Times, "OIT joins Bethlehem Steel, Alliance to Save Energy in showcasing energy saving technologies for industry," Summer 1998, available at http://www.oit.doe.gov/oittimes/sm98/98smpg1.shtml

http://www.oit.doe.gov/steel/ 


\section{Industrial Assessment Centers}

The Department of Energy's Office of Industrial Technologies has funded Industrial Assessment Centers (IACs), formerly known as Energy Analysis and Diagnostic Centers, since 1976. These IACs conduct successful, energy-saving industrial assessments of small- and mid-size manufacturing facilities. Through 1997 ,

- More than 7,600 audits have been completed.

- Audits recommended plant modifications with annual savings of more than $\$ 470$ million (in 1997 dollars) and energy conservation exceeding 83 trillion British thermal units (Btus).

- Almost $40 \%$ of the recommendations and suggestions generated by IAC audits have been accepted and acted on by industrial firms.

- OIT has spent $\$ 46,787,000$ on the program which has led to plant modifications with the potential to save industry more than $\$ 1.575$ billion, better than a 7:1 total benefit to cost ratio.

\section{The DOE Role}

IAC industrial assessments, conducted by university engineering students under the guidance of trained faculty members at 30 participating schools, involve a thorough examination of the potential savings from energy efficiency and conservation improvements, waste minimization and pollution prevention, and productivity improvement. Assessments include pre-visit analyses, site visits and collecting engineering measurements. The team then performs a detailed analysis, generating specific recommendations with related estimates of costs, performance, and payback

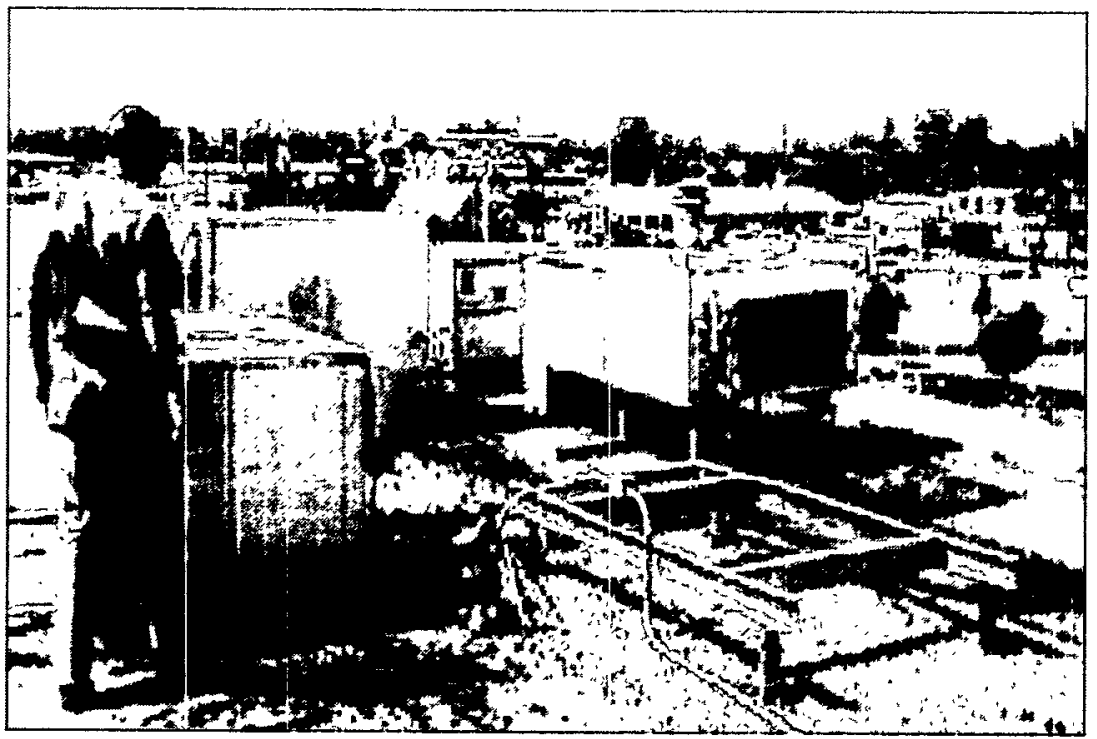

Site visits, as shown here, are an important component of the success and utility of IAC assessments. periods.

The IAC program is designed to reach out to small and medium-sized manufacturers that don't necessarily possess the in-house expertise or funds for energy-related projects that larger manufacturers may have available to them. Energy costs are often a larger portion of total expenses for these small and medium-sized firms, thus IAC assessment-identified savings can have a considerable effect on the competitiveness of these firms. 


\section{Benefits and Costs}

The estimate of energy savings given 40 percent of the IAC recommendations are implemented is conservative. The realization rate, that is, actual energy savings compared to estimated (recommended) savings, could be higher than 40 percent. Data from seven isolated studies performed by individual IAC's found implementation rates for energy-conservation recommendations between 48 and 65 percent. The average realization rates for demand side management energy conservation programs is 0.94 to 1.0 , based on a review by Oak Ridge National Laboratory of many studies of these programs.

Although the details from assessments are held confidential, several projects' findings have been released, illustrating the success of this program and the benefits to be realized from implementing recommendations. An IAC assessment of a plastic cup (expanded polystyrene) factory made many recommendations, including the following:

- Relocating air intakes allows compressors to operate more efficiently and with greater available capacity, resulting in potential energy and maintenance cost savings of $\$ 17,000$ per year and an increase in profits, through increased production, of $\$ 65,000$ per year.

- Replacing a compressed air product transport system with blowers could save $\$ 20,000$ per year in energy costs.

- Using engineered nozzles to replace inadequate orifice fittings has the potential to provide an energy cost savings of $\$ 35,000 /$ year.

- Making changes to the production line, such as replacing the compressed air system with a mechanical system to remove cups from molds, would save $\$ 130,000$ per year in warehouse leasing costs.

Other examples of successful IAC projects include an assessment of a bottlemaking facility that returned energy savings and productivity recommendations with the potential to save $\$ 400,000 /$ year, and an assessment at a tire manufacturing facility that implemented IAC-recommended modifications, realizing an additional \$2.4 million in sales while reducing energy consumption. DOE estimates the IAC Program will save industry $71 \mathrm{tBtu}$ and $\$ 300$ million annually by 2000 while reducing carbon emissions by 1.51 MMT.

\section{For More Information}

For more information, please visit the IAC homepage at http://www.oit.doe.gov/iac/ 
Procass Mechanicel and Electrical Fagdback

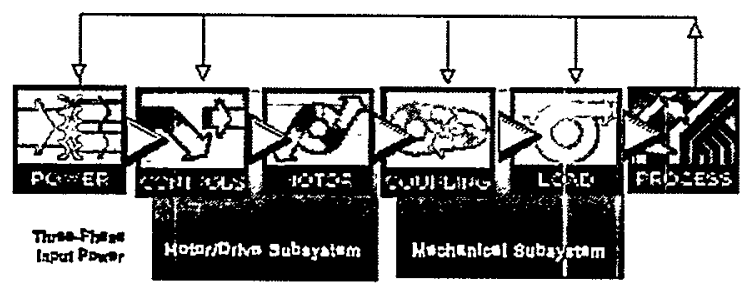

DOE's Motor Challenge program is an industry/government partnership that works to increase the market penetration of energy-efficient motor-driven systems. These systems reduce energy demand, lower emissions, and assist industry to maintain its competitiveness. A key element in the Motor Challenge strategy is to encourage a new "systems approach" to how motors, drives and motor-driven equipment are engineered, specified, and

maintained by industry. Funded at $\$ 6.23$ million in FY1998, Motor Challenge aims to help industry realize electricity cost savings of $\$ 370$ million per year based on present electricity costs. Energy savings from just 13 demonstrations are 131 trillion Btu per year, or almost $\$ 2$ million per year in cost savings.

\section{The DOE Role}

Motor Challenge is a network of resources that supplies free, unbiased, reliable information tailored to help industrial partners make key decisions about motor system purchasing and design. Motor Challenge services include:

- The Information Clearinghouse, which handles roughly 35,000 requests for information per year, serves as a one-stop shop for Motor Challenge information, tools and resources,

- The National Technical Assistance Service provides industrial partners access to the Clearinghouse engineering staff to gain insights concerning possible solutions to problems faced at their facilities,

- MotorMaster and ASDMaster software packages and related training materials assist users in selecting and operating energy-efficient motors and adjustable speed drive systems.

- Partnerships with original equipment manufacturers (OEM), trade associations, industrial entities, and utility companies to identify opportunities for highly-leveraged joint development of new tools and information and disseminate these to industrial end-users.

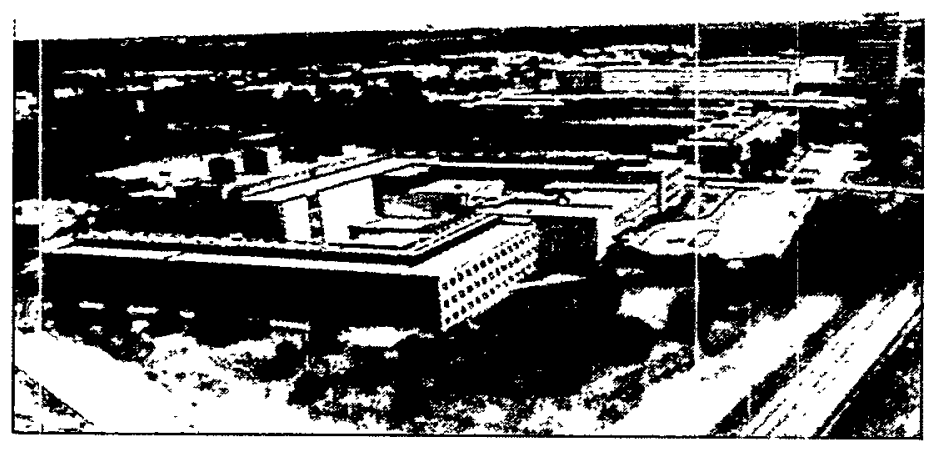

In May, 1995, Minnesota Mining and Manufacturing (3M) and the Office of Industrial Technologies joined forces to conduct a Motor Challenge Showcase Demonstration project at $3 \mathrm{M}$ Center, the company's corporate headquarters and research and development campus. The Demonstration examined energy consumption at a campus building, viewing the individual building as a distinct entity within a larger whole. Specific equipment upgrades or replacement decisions at $3 \mathrm{M}$ were based on financial and operational objectives, and implemented projects were intensively measured and monitored to compare actual savings 
to predicted savings. DOE provided analysis tools that broadened the scope of the energy projects and guidance on what to measure before and after the retrofits.

Four improvements suitable for in-depth study were identified by the Demonstration methodology developed for use in Building 123. Upgrading the air and water supply systems and retrofitting energyefficient motors resulted in the following savings:

- $41 \%$ reduction in electricity consumption from four upgrades

- Annual savings of $\$ 77,554$ on a $\$ 79,499$ investment (including demand-side management incentives provided by the local utility); giving a payback period of 1.03 years

- Annual emission reductions of 1.2 million tons of $\mathrm{CO}_{2}, 2,900$ pounds of $\mathrm{SO}_{\mathrm{x}}, 3,400$ pounds of $\mathrm{NO}_{\mathrm{x}}$, 240 pounds of TSP, and 33 pounds of VOCs

$3 \mathrm{M}$ Center is a large, complex campus (approximately 1000 electric motor systems serve the 7.5 million square foot headquarters). Applying the lessons learned from Building 123 to other campus facilities offers tremendous projected savings opportunities shown in the table below.

\section{Benefits and Costs}

Industrial motor systems represent the largest, single, electrical end use in the American economy-25\% of the Nation's electricity consumption. Using proven, cost-effective technologies today can save manufacturers approximately 11 to $18 \%$ of current annual motor system energy usage ( 75 to 122 billion $\mathrm{kWh}$ ), which would result in savings ranging from $\$ 3.6$ to $\$ 5.8$ billion annually. The energy and cost savings from just 13 demonstration projects, including the $3 \mathrm{M}$ campus discussed above, without any replication throughout industry, are almost $\$ 2$ million per year as shown in the table below.

\begin{tabular}{|l|l|c|c|c|c|}
\hline $\begin{array}{c}\text { Demonstration } \\
\text { Partner }\end{array}$ & \multicolumn{1}{|c|}{ Type of Plant } & $\begin{array}{c}\text { Energy } \\
\text { Savings } \\
\text { kWh/Year }\end{array}$ & $\begin{array}{c}\text { System } \\
\text { Savings }\end{array}$ & $\begin{array}{c}\text { Annual } \\
\text { Cost } \\
\text { Savings }\end{array}$ & $\begin{array}{c}\text { Payback on } \\
\text { Investment, } \\
\text { Years }\end{array}$ \\
\hline 3M Company & Laboratory Facility & $10,821,000$ & $6 \%$ & $\$ 823,000$ & 1.9 \\
\hline $\begin{array}{l}\text { Louisiana- } \\
\text { Pacific }\end{array}$ & Strand board & $2,431,800$ & $5 \%$ & $\$ 85,100$ & 1.0 \\
\hline $\begin{array}{l}\text { Nisshinbo } \\
\text { California }\end{array}$ & Textiles & $1,600,000$ & $59 \%$ & $\$ 100,954$ & 1.3 \\
\hline Alumax & $\begin{array}{l}\text { Primary aluminum } \\
\text { production }\end{array}$ & $3,350,000$ & $12 \%$ & $\$ 103,736$ & 0.0 \\
\hline $\begin{array}{l}\text { City of Long } \\
\text { Beach }\end{array}$ & $\begin{array}{l}\text { Municipal waste } \\
\text { incineration }\end{array}$ & $3,661,200$ & $34 \%$ & $\$ 329,508$ & 0.8 \\
\hline Bethlehem Steel & $\begin{array}{l}\text { Fan system on basic } \\
\text { oxygen furnace }\end{array}$ & $15,500,000$ & $50 \%$ & $\$ 542,600$ & 2.1 \\
\hline $\begin{array}{l}\text { Other } \\
\text { Showcases }\end{array}$ & Various & $1,299,734$ & $31 \%$ & $\$ 181,432$ & 2.16 (avg.) \\
\hline Total/Average & $\begin{array}{l}38,663,734 \\
\text { or } 131 \mathrm{tBtu}\end{array}$ & $35 \%$ & $1,984,898$ & 1.18 \\
\hline
\end{tabular}

\section{For More Information}

Scheihing, Paul E. (U.S. Department of Energy, Office of Industrial Technologies) et. al., "United States Industrial Motor-Driven Systems Market Assessment: Charting a Roadmap to Energy Savings for Industry," available at http://www.motor.doe.gov/docs/utrecht.shtml 


\section{Clean Cities Partnership Program for Alternative Fuels}

The DOE Clean Cities Program is a voluntary, locally based, government/industry partnership to expand the use of alternatives to gasoline and diesel fuel by accelerating the deployment of alternative fuel vehicles (AFVs) and by building a local AFV refueling infrastructure. Alcohol fuels liquefied petroleum gas, electricity, and compressed natural gas are considered to be the principal alternatives to gasoline. Over the past four years, approximately 70 communities across the country have joined the national Clean Cities effort, bringing with them approximately 139,000 AFVs in both public and private fleets, and 3,900 alternative refueling stations. These vehicles reduced gasoline and diesel fuel use by an estimated 132 million gallons and carbon emissions by an estimated 230,000 metric tons in 1998 .

There are a number of significant Clean Cities success stories, including the Tulsa Public School District, which operates 190 vehicles to run on compressed natural gas and propane. El Paso, Texas, recently celebrated becoming the first city in the nation to meet DOE's $100 \%$ niche market alternative fuel vehicle challenge. The El Paso U.S. Postal Service fleet is now $100 \%$ alternatively fueled, with all its 397 delivery trucks operating on compressed natural gas. In

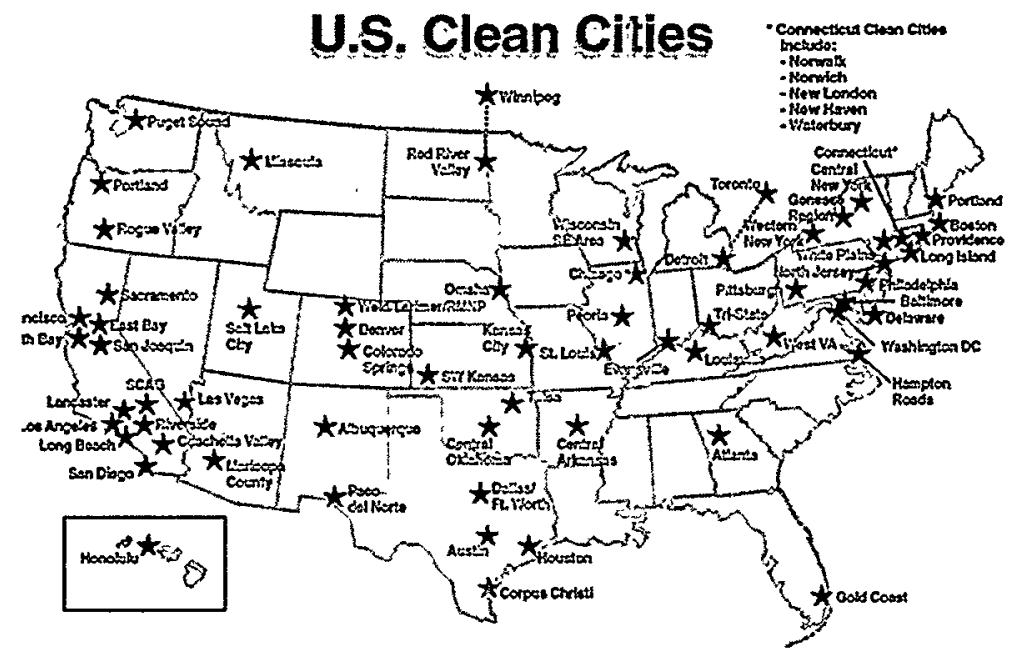
southern California, the Long Beach Clean Cities Coalition brought together the City of Long Beach, L.A. Checker Cab Company, Southern Cali-fornia Gas Company, and Pickens Fuel Company, which resulted in the deployment of 140 natural-gas-fueled taxicabs. The benefits from this partner-ship include reducing non-methane organic gas emissions by 6,352 lb/year, carbon monoxide by 92,511 lb/year, and oxides of nitrogen by $11,101 \mathrm{lb} /$ year.

The Clean Cities Program has also been a magnet for other federal funding, attracting approximately $\$ 275$ million for alternative fuel projects from the Federal Highway Adminsitration. Estimated energy savings from the 139,000 AFVs in Clean Cities Program are equivalent to 0.048 quadrillion BTUs. From 1993 to 1998, cumulative savings of 380 million gallons of motor fuel. This has avoided the emission of 0.40 million metric tons of carbon into the atmosphere and has saved about $\$ 900$ million in oil-based fuels over the life of the program.

DOE's Clean Cities Program has awarded $\$ 9.6$ million to fund 117 projects with matching funds, which includes co-funding from private sector and local governments. Most grants are less than $\$ 100,000$ and are administered by the host state's energy office. Cumulative DOE funding for the Clean Cities Program is approximately $\$ 15$ million. This funding has been matched by a total of $\$ 36$ million from state organizations, participating stakeholders, local alternative fuel suppliers, and others.

\begin{tabular}{|ll}
\hline & References \\
\hline http://www ccities doe gov
\end{tabular}

http://www.ccities.doe.gov 
The National Biomass Ethanol Program encompasses research and development projects aimed at developing a competitively successful domestic industry based on converting cellulosic biomass to ethanol for use as a clean-burning alternative to gasoline. The program is a critical element in The U.S. strategy to decrease dependence on foreign sources of petroleum while reducing atmospheric carbon emissions. $R \& D$ activities have initially focused on improving the efficiency of the biomass-to-ethanol

This facility [in Jennings, Louisiana] is a giant step toward alternative fuels that are domestically produced and based on lowpolluting energy sources. We can look forward to the day when a ton of biomass will be traded like a barrel of oil is today.

\section{-Bill Richardson, U.S. Secretary of Energy} conversion processes.

Waste biomass such as forestry and wood waste, sugar cane residue, rice hulls, and other organic material is significantly cheaper than traditional feed stocks such as corn and grain, but its chemical composition

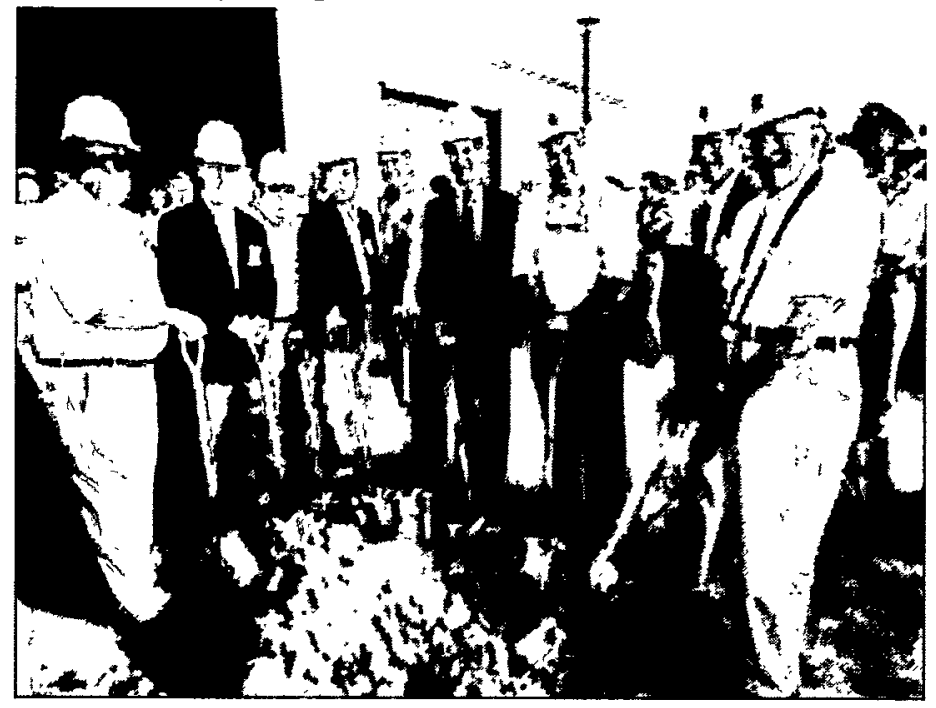
has prevented it from being used to make ethanol economically. Ethanol produced by conversion of waste biomass will now be economically competitive with fossil fuels for the first time because of technological breakthroughs made by the National Biomass Ethanol Program.

Ground was broken for the first commercial biomass-to-ethanol plant in October 1998 in Jennings, Louisiana. BC International Corporation will use a patented, genetically-engineered microorganism in its process of converting organic material to ethanol, a form of alcohol used as an industrial chemical and as "clean-burning" motor fuel. The new plant is expected to produce 25 million gallons of ethanol per year.

DOE has invested $\$ 11$ million towards the retrofit of an existing industrial site in Jennings to accommodate the new technology for producing ethanol. The total renovation cost is estimated to be $\$ 90$ million, for which the private sector is providing about $88 \%$ of the total capital investment. A cogeneration facility will also be built to produce the plant's electrical power. The facility will eventually employ 50 full-time personnel.

\section{Benefits and Costs}

While the appropriations for the national biomass-to-ethanol program have been relatively modest (e.g., about $\$ 130$ million through 1998), the benefits are expected to be quite large. For example, the use of ethanol blends in gasoline is estimated to have displaced 1.53 quads (worth $\$ 12$ billion) oil-based fuels 
through 1998 , thereby reducing carbon emissions by 5.0 million metric tons. The ethanol produced by the Jennings plant is expected to displace almost one-half million barrels of imported oil annually.

\section{References}

U. S. Department of Energy, Office of Fuels Development, Office of Transportation Technologies, "National Biomass Ethanol Plan," FY 1999 - 2005 (Dec. 3, 1998), Draft. 


\section{FEMP AND REGIONAL OFFICES HELP DEPLOY EXISTING TECHNOLOGIES}

The Federal Energy Management Program (FEMP) and EERE's Regional Offices (ROs) are critical links in bringing programs and technologies to federal agencies and local communities. Working with state energy and weatherization offices, and in partnership with other federal agencies, these programs and offices promote energy efficiency through a broad range of EERE activities that provide information, technical assistance, and financial help to local, state, and regional customers, as well as to other federal agencies. A sample of their accomplishments is described below.

\section{The Forrestal Building Relighting Project}

DOE has achieved significant energy efficiency improvements in its own headquarters building (the James A. Forrestal Building) in Washington, D.C. In 1989, a team of energy specialists from the Federal Energy Management Program identified lighting as an area in which energy use could be reduced substantially. A monitoring program showed that the building's more than 34,000 1-foot by 4-foot fluorescent lighting fixtures were responsible for $33 \%$ of the building's total annual electric bill. Innovative financing was required to invest in improved lighting because government-appropriated capital funds were unavailable.

After issuing a request for proposals, a contract was awarded to EUA Cogenex Corporation of Lowell, Massachusetts. Work begin in March 1993. The finished project met all of DOE's goals. As a result of the new lighting system:

- Annual energy lighting consumption was reduced by approximately 6 million $\mathrm{kWh}$.

- Annual savings are estimated to be about $\$ 400,000$.

- Lighting power density was reduced from 2.2 to 1.0 watts per square foot.

- Lighting levels were increased from 43.4 to 58 footcandles.

According to DOE's facilities manager, the project was an unqualified success: "The total building electrical energy consumption was reduced by $18 \%$ as a result of this project, which was made possible by alternative financing. Significant energy savings were achieved while the overall lighting quality throughout the building improved."

\section{The Seattle Regional Office Community Initiative}

To target resources to best meet the comprehensive needs of communities in the region, the Seattle Regional Office has been implementing a Community Initiative since January 1997. The staff identify communities interested in participating; make joint presentations (with state energy offices, EPA staff, or others) to community leaders; develop projects and broker assistance from existing resources to meet community needs; and follow up to determine results: The DOE cost has been about $\$ 25,000$ to date. Here are some of the early results of these efforts:

- In Los Angeles DOE provided design assistance to the city for the $\$ 50$ million redevelopment of the Pico Aliso Public Housing project. The state has agreed to incorporate several of the "green" design recommendations into Pico Aliso and subsequent public housing construction and retrofit projects. The city began development of a green housing initiative centered in its Empowerment Zone and joined DOE's Rebuild America Program. 
- After a joint presentation by DOE, the California Energy Commission, and Center of Excellence for Sustainable Development to city and county staff in San Diego, the city made a commitment to expand its existing efforts with DOE and develop a broad-based city energy efficiency effort tapping the resources of EERE's Rebuild America, Clean Cities, and Motor Challenge programs.

- In March 1998, DOE, ICLEI, state officials, and EPA staff made a joint presentation to city officials in Tucson, Arizona. Numerous resource commitments were made to help the city reduce greenhouse gas emissions. The city helped form a Million Solar Roofs coalition and is likely to join Rebuild America.

\section{Energy Efficient Buildings in Wake of Flooding in North Dakota}

After damaging floods in Grand Forks, North Dakota, in 1997, the Denver Regional Office consulted with the University of North Dakota's Energy \& Environmental Research Center (EERC) and gave seed money of $\$ 40,000$ to support the center's role as local champion for energy-efficient, sustainable, rebuilding strategies. As a result, energy efficiency, previously not considered in rebuilding plans, was incorporated into many new buildings and reconstructions:

- Grand Forks County Building was rebuilt with energy-efficient insulation, lighting, windows, daylighting strategies, and control systems, which will result in estimated energy costs of $\$ 0.71$ per square foot compared to the $\$ 1.50$ per square foot for conventional buildings in the area.

- First Presbyterian Church rebuilt using a passive solar design, energy-efficient windows, and a geothermal heat pump. Bible Baptist Church also installed a geothermal heat pump.

- University of North Dakota became a Rebuild America Partner.

- A local citizen learned about geothermal heat pumps through EERC's outreach and donated $\$ 50,000$ to install the technology in the Grand Forks Library.

- Cavalier Air Station, outside Grand Forks, responded to EERC's outreach by allocating $\$ 50,000$ for a feasibility study of geothermal heat pumps for the facility.

\section{The Rebuilding of Valmeyer, Illinois}

After it was destroyed by flooding in 1993, the City of Valmeyer, Illinois, decided to relocate and rebuild on higher ground. The mayor asked EERE to help design the new town. EERE's Chicago RO assembled a team of national experts who held four design charrettes for the community over a four-month period, educating community members about energy efficiency, solar access, and sustainable community principles. The Illinois Energy Office contributed by offering incentive packages of $\$ 1,300$ each to homeowners who volunteered to meet progressive energy-efficiency standards that far exceeded national standards. The results of this assistance were:

- $30 \%$ savings in energy use (resulting from approximately $40 \%$ heating and hot water energy savings and $20 \%$ reduction in overall electricity use); 
- many homes were built to high energy efficiency standards, including 49 which received energyefficiency grants; and

- the school system has realized a $\$ 50,000$ per year savings from energy-efficient rebuilding, and the Fire Station/Civic Center has realized an energy savings of $\$ 30,000$ per year.

\section{Hualipai Tribe Uses Photovoltaic Pumping System and Water Pipeline}

Northwestern Arizona's Hualapai tribe in Peach Springs, Arizona, has limited income sources and a 70\% unemployment rate. The tribe's tourist facility on the Grand Canyon rim drew some 500 visitors per day, but lacked the necessary water supply to support their expansion potential. Lack of water also limited stock-grazing options. DOE co-funded the purchase and installation of a PV system to pump water 26 miles from a well to the facility and surrounding area.

- The Hualapai Tribe has been able to significantly improve the solar-powered Westwater water pipeline to provide much needed water for cattle and wildlife on this arid portion of the reservation.

- Through their success, the tribe has significantly improved its chances of completing the pipeline to Grand Canyon West, which will in turn open opportunities for economic development and employment for tribal members.

\section{Southwestern U.S. Postal Service moves to Alternative Fuel Vehicles}

In September 1998, the U.S. Postal Service (USPS) in El Paso, Texas, celebrated becoming the first city in the nation to meet DOE's 100\% alternative fuel vehicle challenge. The El Paso postal fleet is the first in the nation to commit to operating all of its 397 delivery vehicles on compressed natural gas.

- The Southwest Region of the USPS now operates over 1,500 bi-fueled, compressed natural gas vehicles, of which 950 are in Dallas - Fort Worth. The vehicles are refueled at 23 public/private fueling stations throughout the metroplex.

- During 1998, five 9-ton USPS trucks operating on liquefied natural gas were put into operation in the Dallas - Fort Worth area. This is USPS's first large-scale demonstration of using liquefied natural gas to fuel heavy-duty trucks. By mid-1999, USPS plans to convert all 128 of the 9-ton trucks operating from the Dallas - Fort Worth bulk-mail center to liquefied natural gas.

- On January 13, 1999, The USPS Southwest Region dedicated its first-of-a-kind environmental postal facility in Fort Worth. This new design concept for post offices features the efficient and sustainable use of natural resources, natural landscaping and rainwater harvesting system, compressed wheat straw wall construction, energy-efficient heating, cooling and lighting systems, use of recycled materials, and use of alternative-fuel vehicles.

\section{Aquaculture Industry Develops in North Carolina}

The Energy Division of the North Carolina Department of Commerce is helping farmers across the state learn about a new year-round cash crop: fish. Before now the state's marine fisheries industry has been 
limited almost exclusively to its coastal waters, and annual productivity was being affected by environmental impacts and fuel price instabilities.

- Utilizing nearly $\$ 400,000$ in Exxon petroleum violation escrow (PVE) funds, the division, in a joint venture with North Carolina State University in Raleigh, is leading the development of warm- and cold-water aquaculture systems that can be used to raise a variety of fish species. The project is being carried out under the auspices of North Carolina's State Energy Conservation Program. Both systems are closed-loop designs utilizing energy-efficient technology created in the Scandinavian countries, which minimizes the amounts of water and energy required and allows for control of temperature, permitting year-round operation Because they are closed-loop systems they are not vulnerable to environmental impacts as are open-water fishing industries.

North Carolina's aquaculture industry has until recently been confined to the eastern and mountain areas of the state. With this technology, the only one of its kind in North Carolina, tilapia and striped bass are being grown in the warm-water system. It is estimated that a commercial warm-water system could produce 80,000 to 100,000 pounds of tilapia per year. Trout, of which North Carolina is the second largest producer in the nation, and arctic cod are being grown in cold water, and other cold-water species such as salmon and sturgeon will be introduced into this system. The marketing staff at North Carolina State are identifying sites for energy-efficient fish farms, and private capital is being sought to bring these technologies into a wider market. 


\section{AFTERWORD - MORE SUCCESS IN THE PIPELINE}

Many EERE-funded technologies have realized significant advances in the past decade but do not yet have quantified energy or cost savings. Some of these have just recently been introduced into the marketplace; others have yet to be commercialized but hold considerable promise for the future. A sample of these recent R\&D successes is described here. The second half of this chapter describes an array of emerging field verification, deployment, and outreach successes. These emerging successes ensure that investments in EERE programs in the 1990s will continue to deliver benefits well into the foreseeable future.

\section{SUMMARY OF PROJECTED BENEFITS FROM EMERGING R\&D SUCCESSES}

A summary of benefits for a sample of seven EERE emerging R\&D successes was calculated for this report. The seven technologies are identified in the following table, along with additional emerging $R \& D$ successes that are described in more qualitative terms later in this chapter.

\section{A Sample of Emerging R\&D Successes}

\begin{tabular}{|c|l|}
\hline \multicolumn{1}{|c|}{ Buildings } & \multicolumn{1}{c|}{ Industry } \\
\hline$>$ High efficiency refrigerators* & $>$ Combined heat and power systems* \\
\hline & $>$ Lost foam metal casting* \\
\hline Transportaiton & $>$ Nickel aluminides* \\
\hline$>$ Fuel cell technologies & Power \\
\hline$>$ High performance batteries & $>$ Photovoltaic thin film partnership program* \\
\hline & $>$ Biomass gasifiers* \\
\hline & $>$ High-temperature superconducting equipment* \\
\hline & $>$ Solar Two \\
\hline & $>$ Photovoltaic manufacturing \\
\hline
\end{tabular}

*Success metrics for these seven technologies are described below and are summarized in Appendix A.

The DOE R\&D investment represented in these seven EERE accomplishments in emerging technologies collected is $\$ 288$ million over a period of six years (see Table 4 in Appendix A for details). Much of this investment has been matched with cost-shared dollars and resources from industrial partners. Nickel aluminides research is an example of an emerging success that has benefited from funding from several different DOE offices, beginning in 1982. Initial research on nickel aluminides was funded by DOE's Office of Science. As the beneficial applications of this novel material became clear, both EERE and DOE's Office of Fossil Energy supported its further development. Nickel aluminides also received the earliest DOE funding of all these emerging technologies, reflecting the basic research that was first required to develop the scientific basis for this bimetallic alloy. 
The potential energy saved or replaced by these seven emerging technologies is 945 trillion Btu. More than half of this ( 500 trillion Btu) is projected to be saved in 2010 by high temperature superconductivity equipment. An additional 290 trillion Btu will be saved if the efficiency of all refrigerators is improved to the 1 kilowatt hour per day consumption of EERE-developed high-efficiency refrigerators. Widespread use of nickel aluminides could save industry 60 trillion Btu per year while lost foam metal casting, already in use in aluminum and iron casting, will save 37 trillion Btu when it has gained sufficient market share to reduce energy requirements for melting by 30 percent.

Energy cost savings from the adoption of these seven emerging technologies could save billions of dollars in the future. For example, $\$ 6$ billion could be saved annually if all refrigerators used just 1 kilowatt of energy per day, as demonstrated by DOE. The application of high temperature superconductivity to reduce losses from the transmission and distribution of electricity could save $\$ 564$ million by 2010 . The use of nickel aluminides will save industry $\$ 180$ million, and another $\$ 160$ million in cost savings will come from the installation of combined heat and power systems. Estimated reduction in carbon emissions from the adoption of these emerging technologies is nearly 50 million metric tons.

Many other benefits will result from these emerging DOE technologies. Among these is a reduction in solid waste of 700,000 tons per year from the adoption of the lost foam metals casting process and millions of dollars in exports of photovoltaic thin film systems.

\section{A SAMPLE OF EMERGING R\&D SUCCESSES}

\section{Setting a Technology Benchmark for Refrigerator Efficiency}

DOE's Oak Ridge National Laboratory (ORNL), in cooperation with seven industry partners, has designed a refrigerator-freezer that uses half as much energy as current refrigerators and one fifth the energy used by 1972 models. The research team modified a conventional refrigerator using highly efficient technology to reduce energy usage by $50 \%$, from 2 kilowatt hours $(\mathrm{kWh})$ per day to 1 $\mathrm{kWh}$ per day. One $\mathrm{kWh}$ is as much as a $40-\mathrm{W}$ light bulb uses in a single day. The efficiency demonstrated by ORNL's "fridge of the future" helped define a benchmark for future refrigerator efficiency.

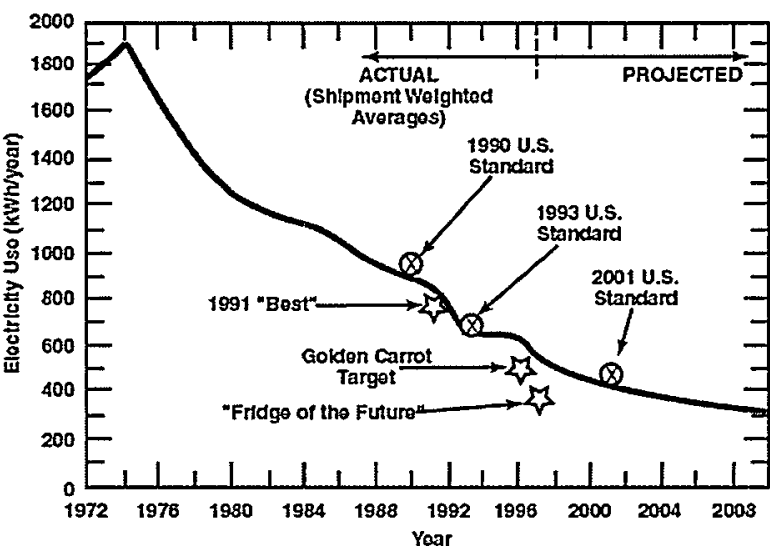

ORNL researchers assembled the prototype by modifying a standard 1996 production model refrigerator using the most promising energy-saving components and features available within companies in the Appliance Research Consortium (ARC), a subsidiary of the Association of Home Appliance Manufacturers. Baseline energy consumption of the original 1996 refrigerator was extensively documented, along with cabinet heat load and compressor calorimeter test results, to provide a firm basis for comparing the energy savings measured in the prototype high-efficiency refrigerator. The results demonstrated the degree of energy efficiency that refrigerator manufacturers could attain using existing technology and a systems engineering approach, and quantifed the costs and the paybacks. All refrigerator manufacturers will likely use one or more of the energy-saving strategies from the "fridge of the future" to meet future energy-efficiency requirements. 
The huge improvement in energy efficiency in refrigerators during the final quarter of the $20^{\text {th }}$ century was facilitated by DOE's long-term R\&D commitment and its collaboration with the appliance industry. This work has resulted in significant savings and has laid the groundwork for realizing equally significant savings in the future.

A DOE investment of $\$ 1.1$ million in R\&D of high-efficiency compressors saved consumers about $\$ 6$ billion in energy costs between 1980 and 1990. These compressors were developed through cooperative research agreements between a leading compressor manufacturer and ORNL and were $44 \%$ more efficient than the compressors they replaced. DOE's $\$ 1.2$ million spent on refrigerator efficiency between 1991 and 1997 could save consumers another \$6 billion per year and could displace 290 tBtu of energy and 12 MMTC of carbon emissions annually.

If the energy used per refrigerator dropped to $1 \mathrm{kWh}$ per day-the efficiency achieved by the prototype "fridge of the future"-energy use by refrigerators would drop from $2.1 \%$ to $0.8 \%$ of the total energy used in the United States, saving another $\$ 6$ billion per year. A prototype built with a fewer if these efficient technologies would save slightly less energy but achieve a payback period of less than three years because its manufacturing cost would be only $\$ 18$ more than the baseline model.

\section{Combined Heat and Power (CHP) Systems}

Combined heat and power (CHP) systems are designed to concurrently generate thermal energy and electrical/mechanical energy, capturing waste heat and using it to heat and cool buildings or to provide steam for use in industrial processes. DOE is an active supporter of research, development, and deployment of CHP systems, with involvement dating back to the 1980s. CHP plants use of waste heat results in total system efficiencies of 70 to 90 percent - a considerable performance gain over the 33 percent average efficiency of conventional central electricity generating plants.

Combined heat and power systems, many of which combust natural gas to achieve their significant environmental benefits, universally demonstrate considerable energy and cost savings. Some of these successes include:

- In the late 1970's, DOE and the Minnesota Energy Agency, with partners Building Owners and Manufacturers Association and the U.S. Department of Housing and Urban Development, began a partnership in the city of St. Paul, Minnesota to study the feasibility of modern district heating systems. The resulting community-based organization, District Energy St. Paul, has grown and proven itself a valuable real-world CHP demonstration project. The system has been continually retrofitted over the past two decades with the best available technologies, doubling system efficiency while adding services such as district cooling.

- The Department of Energy-installed cogeneration plant at the Naval Petroleum Reserve No. 1 in California supplies all electricity and steam requirements for the field. 45 percent more efficient than the private sector plant from which the Reserve once purchased power, the facility generates annual revenue in excess of $\$ 3$ million. The CHP plant provides 160,000 pounds of steam per hour, allowing the Reserve to shut down less efficient gas heaters and steam boilers.

- Malden Mills, in Lawrence, Massachusetts, installed a cogeneration system to replace generating and heating equipment destroyed in a fire. Following the recommendation of OIT's Advanced Turbine Systems program, they installed a natural gas turbine-based cogen system. In one year, Malden will retrofit the turbines with ceramic liners developed within the ATS program. Once installed, this 
natural gas turbine-based system will lower the company's annual energy costs and reduce emissions of $\mathrm{SO}_{2}$ by 99.6 percent, $\mathrm{NO}_{x}$, by 83 percent and $\mathrm{CO}_{2}$ by 26 percent relative to grid-supplied power.

\section{Lost-Foam Metal Casting Improves Quality, Reduces Energy Consumption}

The DOE Office of Industrial Technologies, working with the Lost Foam Casting Consortium, has aggressively pursued development and demonstration of an advanced casting technology termed "lost foam." Lost foam casting is a highly flexible casting process that allows complex metal components to be cast into final or near-final form, reducing waste and additional energy expenditures incurred by the extensive milling process required in conventional casting. An estimated 40,000 tons of lost foam aluminum castings were produced in 1994, rising to 50,000 tons in 1997 . Growth through the year 2000 is expected to increase by 64 percent, to 82,000 tons. Lost foam casting of iron is also growing, with production increasing from 20,000 tons in 1994 to 40,000 tons in 1997 , to an estimated 85,000 tons in the year 2000 .

\section{Metal Casting Vision Research is Producing Results:} Aluminum Lost Foam Castings

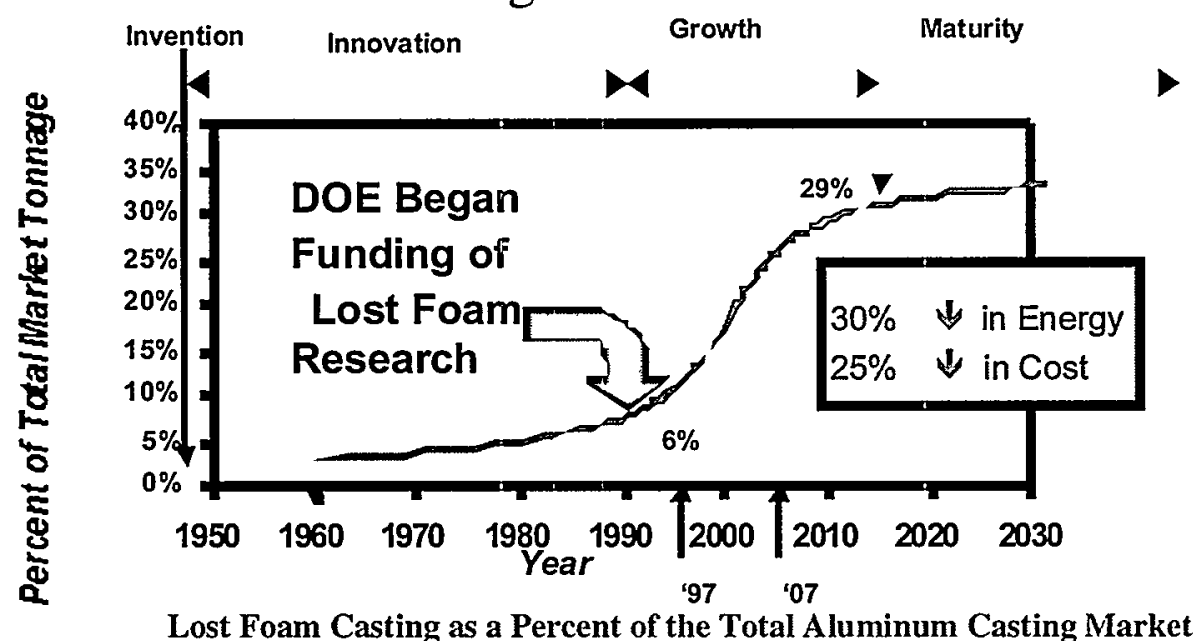

This DOE/private partnership, begun in 1990, is part of DOE's Metal Casting Program. DOE funded $\$ 1,557,742$ worth of lost foam research over the period FY1992 to FY1997, largely at the University of Alabama Birmingham. Industry cost-share during the same period totaled $\$ 1,975,391$. Work has been completed in several areas of the casting process, including patterns, coatings, sand reaction, and properties of the castings.

The benefits to be realized from the precision lost foam casting process include:

- The lost foam process requires less metal to be melted than other processes. An estimated 30 percent reduction in energy requirements for melting could save about 37 trillion Btu per year, or $\$ 78.44$ million. 
- The process led to a 17 percent reduction in distortion scrap by one partner foundry, and a scrap reduction rate drop of 5.5 percent to 0.25 percent in another partner foundry. Overall potential is a reduction of 700,000 tons/year of solid waste by the year 2000 .

- Lost foam tooling life is at least 5 to 6 times that of permanent mold or die cast tooling, saving capital expenditures.

\section{Nickel Aluminide R\&D Increases Operational Efficiency}

Nickel aluminides $\left(\mathrm{Ni}_{3} \mathrm{Al}\right)$ are unique intermetallic materials that combine extraordinary strength and hardness with very high melting points. These materials are potentially useful in such strategic industrial sectors as steel, chemicals, and automobile manufacturing. The harsh conditions under which nickel aluminides display their unique set of properties points to their promising use as rolls and fixtures in steel mill furnaces, as dies for precision parts or as "dies for dies," and in various other high-temperature and extremely corrosive operating environments.

Since 1982 DOE's Offices of Basic Energy Sciences, Fossil Energy, and Energy Efficiency and Renewable Energy together have provided more than $\$ 21$ million toward the successful development of strong, castable, weldable, and ductile nickel aluminides and other intermetallic alloys, and to develop the Exo-Melt production process. In addition, industrial partners have spent over $\$ 12$ million on DOE-related $\mathrm{Ni}_{3} \mathrm{Al}$ materials, applications development, and testing. Industry contributions occur through Cooperative Research and Development Agreements (CRADAs), collaborative materials and process evaluations, and licensing. The work of DOE and its partners has resulted in increased industrial acceptance of these materials and processes, as shown by a growing network of suppliers and users that spurred commercial sales of $\mathrm{Ni}_{3} \mathrm{Al}$ to $\$ 3,000,000$ at the close of 1998 . The total energy savings in heat treatment of steel are estimated at 60 trillion Btu by 2015 at an energy cost savings of $\$ 180$ million per year.

Experiences of industrial partners includes:

- Delphi is using $\mathrm{Ni}_{3} \mathrm{Al}$ heat treating trays in their parts furnaces; results indicate that $\mathrm{Ni}_{3} \mathrm{Al}$ fixtures last more than four times longer than conventional HU trays. Longer tray-replacement periods could result in savings of $\$ 2$ million annually.

- Chevron is testing and utilizing $\mathrm{Ni}_{3} \mathrm{Al}$ tube hangers in chemical reaction systems to alleviate problems with high-temperature corrosion.

- United Defense is realizing reduced total die costs, improved production rates, and increased recycling values using $\mathrm{Ni}_{3} \mathrm{Al}$ forging dies instead of steel dies.

- Bethlehem Steel has installed 21 rolls in a steel slab reheat furnace to decrease furnace downtime while improving product quality, thus saving time and energy, and improving competitiveness. 


\section{Documented Progress on a Time Line Helps Demonstrate Causality}

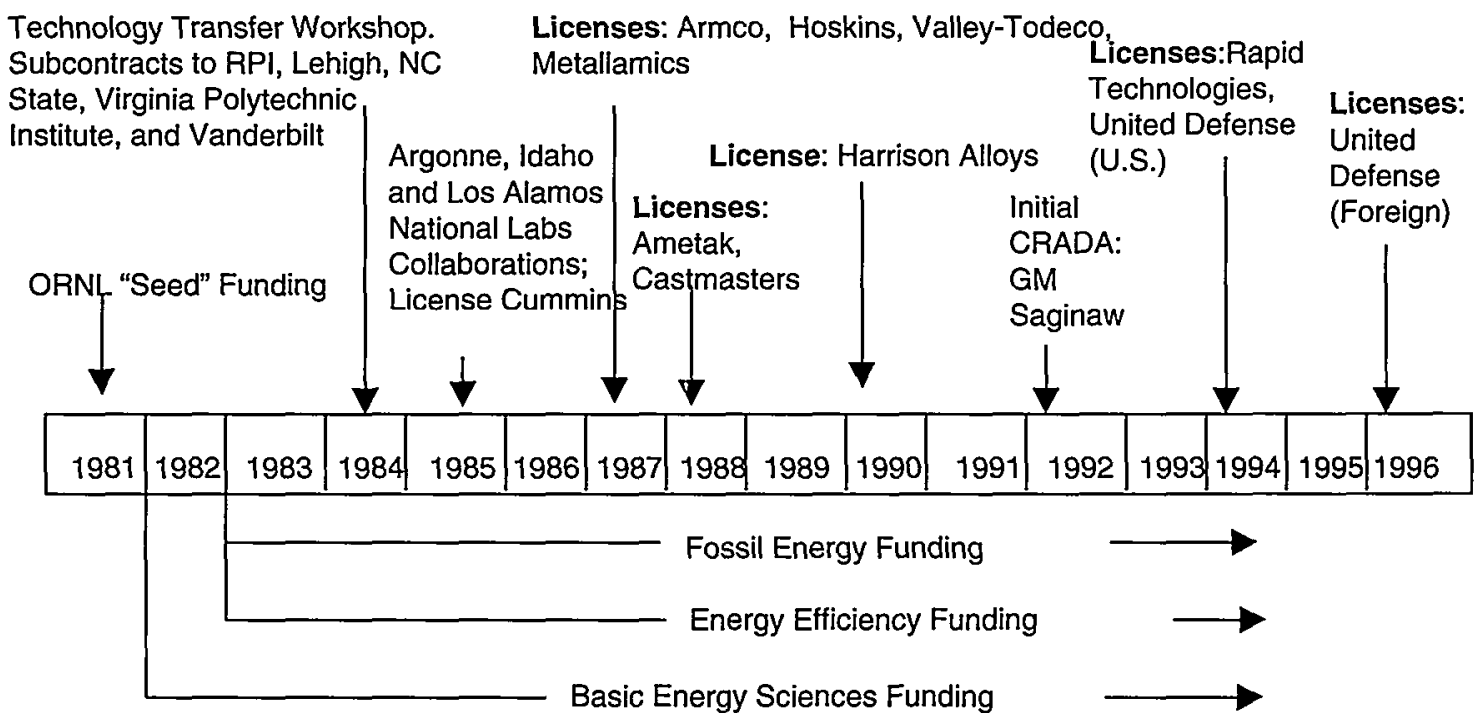

The nickel aluminide program's history of industrial licensing, partnership, and CRADAs shown here is one indicator of the $\mathrm{Ni}_{3} \mathrm{Al}$ program's value as viewed by the private sector. The period over which licenses have been granted suggests a continuing line of scientific advancement, and offers a preview of the uses and savings that industry may realize.

\section{Photovoltaic Thin Film Partnership Program}

Photovoltaics (PV) is an energy technology that makes use of semiconductor materials to convert sunlight directly to electricity. It is basically divided into "wafer" and "thin-film" technologies. Wafer-like solar cells cut from ingots of crystalline silicon have been available commercially for decades. The idea of thin films is relatively simple: produce low-cost PV devices by using materials that are amenable to integrated module manufacturing methods instead of the labor-intensive mechanical configuration of individual cells required by wafer-based PV technology.

Through twenty years of R\&D, DOE has helped pioneer thin-film technology by developing new semiconductor materials such as amorphous silicon, copper indium diselenide, and cadmium telluride (CdTe), which should be less costly to produce in the large panels or "modules" needed for utility-gridconnected applications. In FY1994 DOE established the Thin Film Partnership Program to focus the development of new materials and to help solve industrial problems by funding cost-shared contracts with several thin-film manufacturing companies. The partnership stimulates collaboration among the national laboratories, universities, the PV industry, and ancillary industries. The long-term (2010 and beyond) goal of the partnership is to develop modules that produce 150 watts of power per square meter at a module price of $\$ 50$ per square meter. Reaching this goal will ensure achievement of the long-term DOE goal of a PV system that produces electricity at 6 cents per kilowatt-hour. By the year 2020, thin film technology is projected to displace 17 trillion Btu annually, saving $\$ 54$ million in fuel costs and reducing carbon emissions by 0.25 million metric tons. 
DOE's budget for thin films has averaged $\$ 17$ million per year from 1994 to 1999 . Benefits include advances in thin-film technologies and commitments for the construction of the first four multi-megawatt thin-film production facilities. In January 1999 DOE established a new world record for all thin-film cells with a copper indium gallium diselenide (CIGS) solar cell efficiency of $18.8 \%$, breaking its previous record of $17.7 \%$ set in March 1996 (see graph on the next page). DOE's thin-film R\&D efforts have also been awarded several noteworthy prizes: four R\&D 100 awards, a Discover Award from Discover Magazine, two Federal Laboratory Consortium "Excellence in

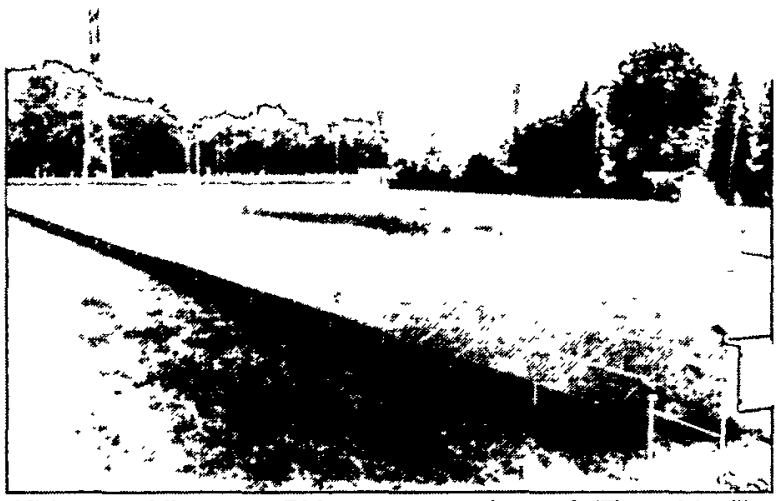

This 10-kilowatt PV array using CdTe thin-film technology feeds electricity into the Toledo Edison utility grid. Solar Cells, Inc. NRELPIX01560. Technology Transfer" awards, and a Popular Science "Best of What's New" award have been received for thin-film materials development.

\section{Biomass Gasifiers: Kindling Biopower Potential}

The world's first demonstration of an efficient, low-pressure biomass gasifier capable of producing a high-quality fuel gas is now operating at the Burlington Electric Department's McNeil wood-fired generating station in Burlington, Vermont. The gasifier, developed by Battelle Columbus Laboratories (BCL) and licensed by Future Energy Resources Co. (FERCO) of Atlanta, Georgia, converts 200 tons of wood chips per day into a gaseous fuel, enough to generate $8 \mathrm{MW}$ of power.

The Vermont gasifier project is part of a major DOE initiative to demonstrate gasification of renewable biomass for electricity production. DOE has provided financial and technical support for the development of the BCL gasifier technology since 1980 in a variety of ways: by supporting the initial laboratory and pilot-scale gasifier tests at Battelle, by providing engineering, scientific and analysis assistance through DOE's National Renewable Energy Laboratory (NREL), and by cost-sharing the scaleup verification tests in Vermont.

The gasifier will significantly improve biomass-to-electricity generating efficiency in applications ranging from stand-alone power generation to the forest products industry. This gasifier will allow biomass to be used with standard gas turbines and combined cycles to produce advanced power systems with efficiencies that can exceed $35 \%$ - nearly double that of today's biopower industry. That means twice as much electricity for each pound of biomass converted, or half as much fuel required for each kilowatt of electricity generated. Because of its economic potential and scientific accomplishment, the gasifier team, including FERCO, Battelle, Burlington Electric Department and NREL, was given an R\&D 100 Award for one of the most significant technical achievements in 1998.

A recent analysis by a consortium of five national laboratories (and consistent with industry estimates) indicates that, if fully adopted, this technology could generate $40,000 \mathrm{GWh}$ of electricity in the forest products industry alone while avoiding 14 million tons of carbon emissions per year. By the year 2010, biomass gasifiers are projected to displace 14 trillion Btu of energy, saving $\$ 2$ million in energy costs and reducing carbon emissions by 0.24 million metric tons. 


\section{High-Temperature Superconductivity}

Superconductivity will bring the most fundamental change to electric power technology since electricity use in the United States became widespread a century ago. Superconductivity is the ability of certain materials to conduct electrical current with no resistance and extremely low losses. Recently discovered high temperature superconductors (HTS) are exciting because they can be cooled more economically and efficiently than low-temperature superconductors. This ability to carry large amounts of current can be applied to electricity transmission in power lines and electric power devices such as motors and generators. In much the same way that fiber optic cables created the "information superhighway," superconductivity will create an "energy superhighway" that greatly increases capacity and energy efficiency. Superconducting technology will also help open the deregulated electricity market to smaller electricity producers by making transmission of electricity more economical.

DOE has championed research for the development of super-efficient electrical systems and has played a critical

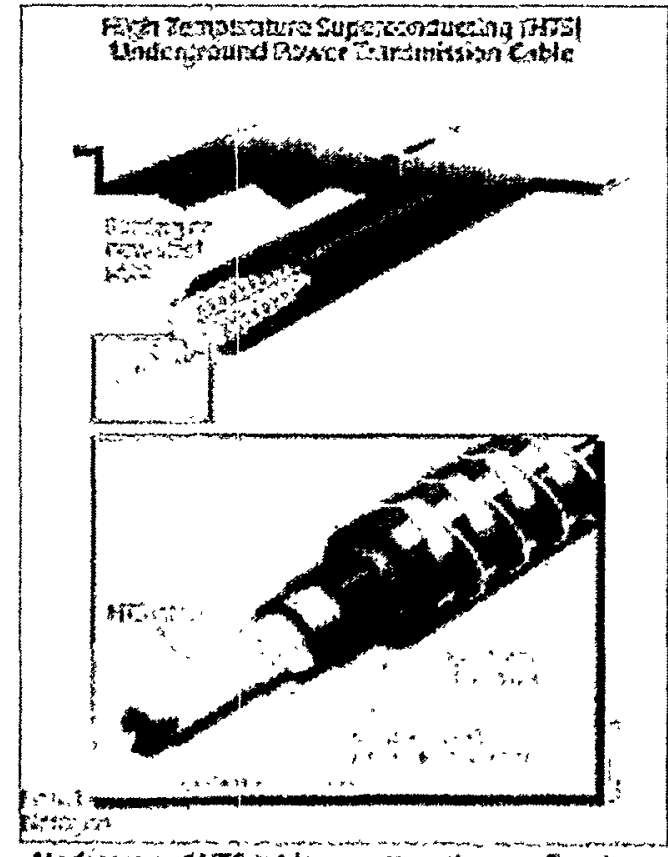

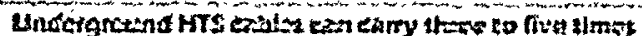

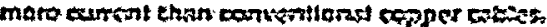
role in mobilizing the private sector, universities, and the national laboratories to conduct research and development and bring HTS technologies to the marketplace. The combined efforts of DOE, companies such as American Superconductor Company, and the national laboratories are now beginning to pay off. In 1999, researchers at DOE's Oak Ridge National Laboratory (ORNL) and a team led by Waukesha Electric have built and tested a 1-million-volt-ampere prototype power transformer. Superconducting transformers are half the size and weight of conventional transformers, and have only half the energy losses.

The world's first urban superconducting power line will become a reality in the year 2000 as part of the DOE program. The equivalent of 30,000 households will be served in a downtown Detroit neighborhood slated for several major redevelopment projects. Team members in addition to Detroit Edison are American Superconductor Co., the Electric Power Research Institute, and Los Alamos National Laboratory.

A recent study funded by DOE suggests that half the $7.35 \%$ of electricity that is lost in transmission and distribution could be saved. The resulting $3.67 \%$ savings (currently equivalent to about 500 trillion Btu), if used to reduce coal-fired electricity generation, would eliminate the emissions of 131 millions tons of $\mathrm{CO}_{2}, 24,232$ tons of $\mathrm{NO}_{\mathrm{x}}$, and 846,000 tons of $\mathrm{SO}_{\mathrm{x}}$, based on 1995 coal plant technology. The projected annual energy benefits in 2010 of HTS for all equipment types is $\$ 564$ million.

\section{High-Efficiency, Low-Emissions Fuel Cell Technologies for Transportation}

The United States can benefit greatly from the commercialization of fuel cell technology. Transportation accounts for $67 \%$ of the petroleum consumption and one-third a balance of trade surplus in the transportation sector. Vehicles powered by fuel cells offer important advantages over conventionally powered vehicles. A fuel processing system could deliver about $85 \%$ of the energy in a gallon of gasoline 
to the fuel cell, and the fuel cell could turn more than half of that energy into electricity for a total system efficiency of over $40 \%$. In contrast, an internal combustion engine uses less than $20 \%$ of the energy in a gallon because of losses including cycle inefficiency and friction. It is estimated that a fuel cell system running on gasoline would achieve double the miles per gallon of a conventional vehicle or 50 to 70 miles per gallon. Fuel cells also promise to be very low in emissions.

DOE recently concluded a cost-shared program with General Motors Corporation to develop a methanolpowered Proton Exchange Membrane (PEM) fuel cell system. At the heart of the system is an on-board fuel processor that converts methanol to hydrogen. After demonstration in the laboratory, General Motors incorporated the technology into its Zafira concept minivan and first displayed the vehicle at the Paris Autoshow in September 1998. Along with partners Arthur D. Little and Los Alamos National Laboratory, DOE has also demonstrated the potential of fuel-flexible fuel processing. The partners demonstrated the conversion of gasoline to electricity with a PEM fuel cell system, which is now the focus of all significant research on fuel cells for light duty vehicles.

The fuel cell development initiative has made impressive strides during the last decade and many of the technical goals, including those set by the Partnership for a New Generation of Vehicles (PNGV), have been achieved. Today the most significant fuel cell developments are being carried out by auto manufacturers and supply companies, including Allied Signal, Ford, Daimler Chrysler, International Fuel Cells, Plug Power, $3 \mathrm{M}$, and General Motors. If fuel cell vehicles comprised $4 \%$ of all light vehicles in use in 2020 , they would reduce gasoline use by 1.8 billion gallons and reduce carbon emissions by 4.7 million metric tons.

Although impressive progress has been made, and development activity both public and private has increased, foreign competition is strong and much work remains before fuel cells can compete with current vehicle technology. Key technical challenges that remain include size and weight reduction, manufacturing cost reduction, rapid start and transient performance, durability and reliability, and fuel processing. The DOE role is to encourage $R \& D$ to overcome these most critical technical barriers to commercialization.

\section{Enhancing the Performance Characteristics of Batteries}

The energy savings and emission reduction benefits of electric vehicles (EVs) are substantial, but the lack of a battery capable of providing sufficient range and performance has long been an obstacle to the deployment of these vehicles. Today's lead-acid batteries have a limited range, allowing drivers to travel only relatively short distances before they must recharge. Current technology provides lead-acid batteries with an energy-to-weight ratio of 30-40 watt hours per kilogram $(\mathrm{Wh} / \mathrm{kg})$ at a cost of up to $\$ 150$ per kilowatt-hour $(\mathrm{kWh})$. The development of batteries that can provide performance comparable to that of conventional vehicles and at comparable cost is key to making electric vehicles practical.

The level of research and development required to adequately develop promising battery technologies is beyond the resources of any one automobile company. To share costs Chrysler, Ford, General Motors, and DOE entered into an agreement in 1991 to develop more efficient batteries for electric vehicles. This partnership is called the United States Advanced Battery Consortium (USABC). DOE's Office of Transportation Technologies manages the cooperative agreement with the consortium and provides technical assistance and funding.

About $\$ 190$ million, cost shared equally between the government and industry, was spent from 1991 to 1996 on battery research. In 1996, a second-phase cooperative agreement worth $\$ 106$ million was signed to continue work through the year 2000. The nickel-metal-hydride (NiMH) battery is the technology that has come closest to meeting midterm USABC goals, while lithium-polymer batteries are the most 
promising for meeting longer-term objectives. Weight for weight, and volume for volume, NiMH batteries can store about twice the energy of the lead-acid battery. The total investment in developing the NiMH battery has been about $\$ 50$ million from 1991 through 1997, including DOE's contribution of about $\$ 25$ million. DOE invested $\$ 15$ million per year in FY 97 and FY 98 , with $\$ 7$ million estimated for FY 99 costs and $\$ 8$ million for FY 00 .

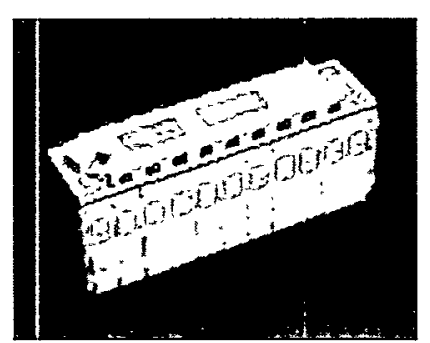

Nickel-metal-hydride battery

Public and private investments in the NiMH battery technology have yielded concrete results. In 1996 a joint venture of General Motors and Ovonic Battery Company-GM Ovonic-began producing its first generation of NiMH EV batteries, which are used in the 1999 model year General Motors EV-1 and the S-10 Chevrolet electric pick-up truck. Daimler Chrysler has also developed a NiMH-powered interurban commuter, the EPIC, which is expected to have a range of 80 to 90 miles. Its NiMH battery is about 150 pounds lighter than an equivalent lead-acid battery. Significant cost and manufacturing challenges remain before electric batteries will be able to realize their full potential. To reduce costs further, the USABC is concentrating on three key areas: raw materials, battery design, and volume manufacturing.

\section{Solar Two: Clean Power on Demand}

Solar Two utilized a field of mirrors to reflect solar energy towards a centrally located tower. A unique molten salt storage system was used that allowed Solar Two to dispatch electricity after sunset and during periods of cloudy weather. Since completing its start-up phase in late 1997, the 10-MW Solar Two pilot plant has proved the potential of molten salt solar power tower technology to deliver large quantities of electric power to the grid reliably, efficiently, and on demand. These successes are critical to gaining investor confidence in large solar power plants.

DOE has provided funding for half of Solar Two's $\$ 60$ million cost, with the remainder provided by a consortium of ten U.S. utilities and industries, performed on-site testing and evaluation of advanced components (e.g., the receiver and heliostats), suggested ways to improve plant performance, and chaired the Solar Two Steering Committee.

Some key recent accomplishments by Solar Two include the following:

- Dispatchability: Utilizing its unique and highly efficient thermal storage system, Solar Two delivered electricity to the grid around the clock for 153 straight hours (nearly a full week).

- Power Output: Solar Two produced 1633 MWh over a 30-day period, exceeding its long-term performance measure of $1500 \mathrm{MWh}$ of power production; the plant also produced a record turbine power output of $11.6 \mathrm{MW}$.

- Reliability: During one stretch in the summer of 1998, the plant operated for 32 of 39 days (4 days down because of weather, 1 day because of loss of offsite power, and only 2 days for maintenance.

- Parasitic Power Use: The electrical parasitic energy load (electricity required to run the plant) was reduced significantly and now routinely meets the design goal.

- Efficiency: The receiver efficiency was measured at $88 \%$, as per design specifications. 
With Solar Two ceasing operations in April 1999, long-term reliability remains an issue that can only be fully resolved by operating a plant reliably over an extended period of time - and results to date suggest that this is an achievable goal.

\section{Photovoltaic Manufacturing Improvements}

Photovoltaic manufacturing costs and capacity will continue to improve over the next few years with the help of the Photovoltaic Manufacturing Technology (PVMaT) Project. Initiated in 1990 to reduce costs and maintain the U.S. PV industry's leadership in developing and manufacturing commercial PV modules and systems, PVMaT is one of the most successful DOE-sponsored R\&D projects in the history of the Photovoltaics Program, helping to reduce module manufacturing costs by $37 \%$ and increase U.S. manufacturing capacity by $276 \%$ from 1992 to 1997. Additional advances are expected to reduce PV module costs to the point where PV

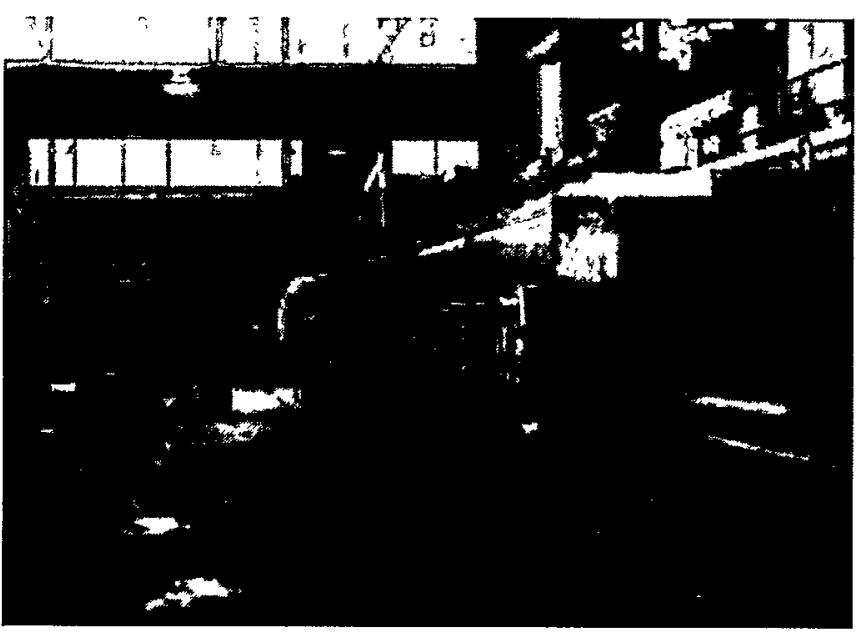
systems are competitive with small diesel systems and grid extensions in many developing countries and in other niche grid-connected applications. These applications represent several billion

Glass Coating Furnace at Solar Cells, Inc. NREL/PIX 04572 dollars' worth of business.

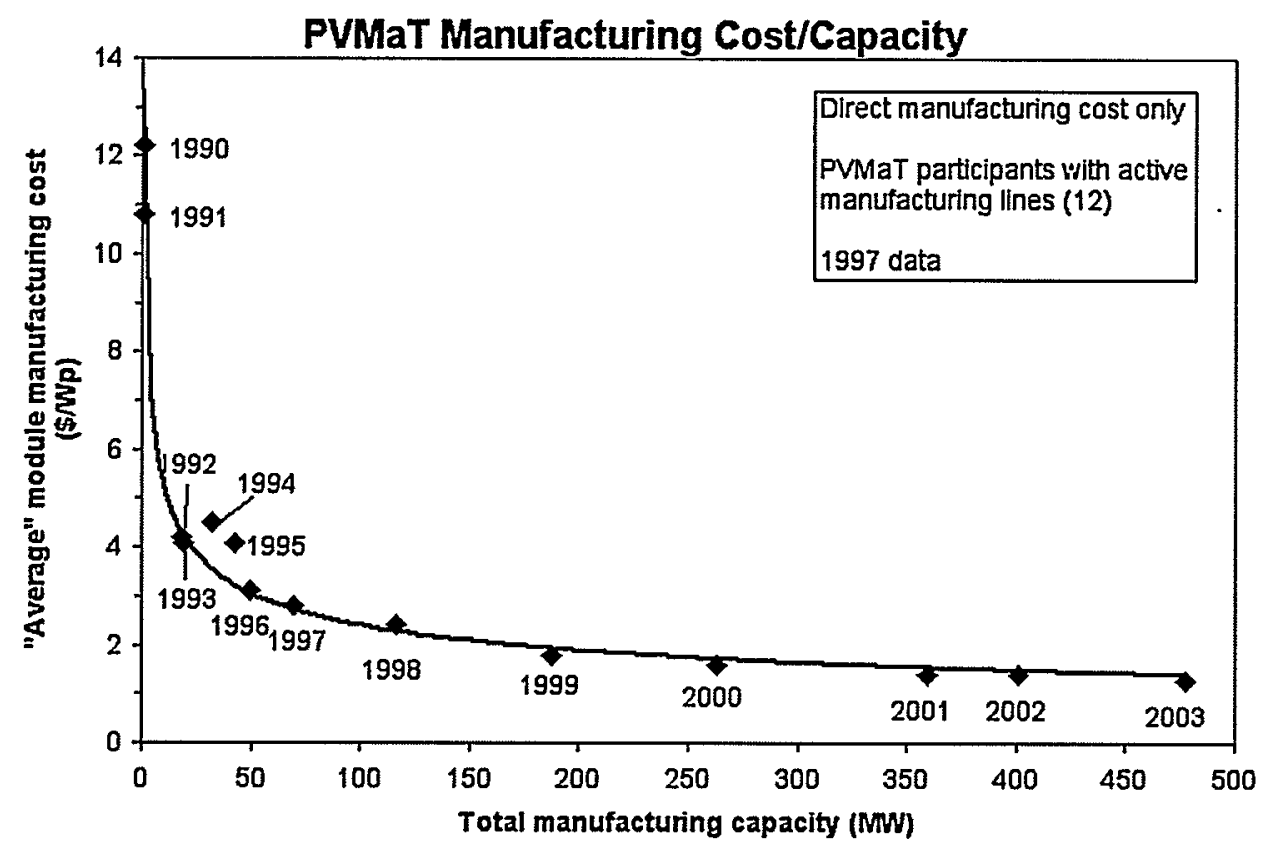


DOE provided $\$ 72$ million in project funds for PVMaT from 1990 to 1998 , with an additional $\$ 50$ million provided by private industry ( $41 \%$ of total project costs). The public has already recouped its portion of the funds spent on this research through a direct reduction in the price of PV products, and has also benefited from the creation of 150 to $1500 \mathrm{jobs}$, an improved trade deficit ( $70 \%$ of these products are sold outside the United States, with $\$ 128$ million worth of modules and cells exported in 1997), and reduced greenhouse gas emissions. This benefit will grow as photovoltaics increase their market penetration within the United States and throughout the world.

\section{A SAMPLE OF EMERGING FIELD VERIFICATION, DEPLOYMENT, AND OUTREACH SUCCESSES}

This section describes 10 field verification, deployment, and outreach successes that have accelerated and expanded the use of efficient and renewable energy technologies. In addition to the nine successes listed by sector in the following table, one cross-cutting accomplishment is described: the Million Solar Roofs Program.

A Sample of Emerging Field Verification, Deployment, and Outreach Successes

\begin{tabular}{|c|l|}
\hline \multicolumn{1}{|c|}{ Buildings } & \multicolumn{1}{c|}{ Federal } \\
\hline$>$ Building America & $>$ FEMP on Target to Meet Goals \\
\hline$>$ Greening Four Times Square & $\begin{array}{l}\text { Renewable Energy Technologies in Federal } \\
\text { Facilities }\end{array}$ \\
\hline & $>$ FEMP Lamp Swap \\
\hline Transportation & $>\begin{array}{l}\text { FEMP Helps Government Buy Energy } \\
\text { Efficient Products }\end{array}$ \\
\hline$>$ Federal Fleet Alternative Fuel Acquisition & $>$ Climate Challenge \\
\hline$>$ High Temperature Materials Laboratory & \\
\hline
\end{tabular}




\section{Building America: Innovation Through Systems Engineering}

The Building America Program brings together teams of architects, builders, contractors, and equipment manufacturers to apply a systems engineering or "whole building" approach to single-family home design and construction. With 100 industry partners, this approach has led to dramatic improvements in energy efficiency at little or no net increase in construction cost.

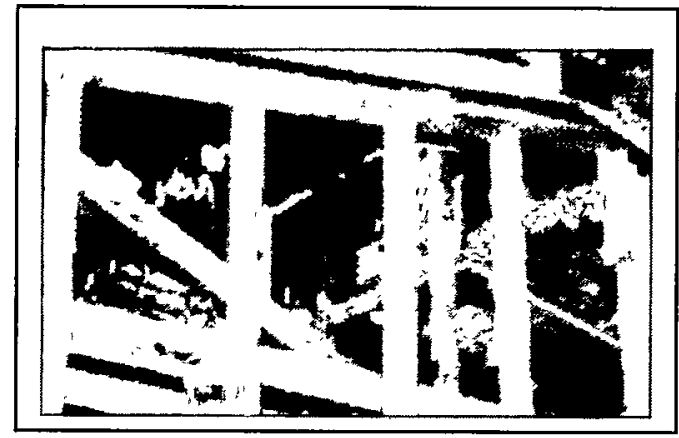

The air handler in this Building America house is installed within the conditioned space.

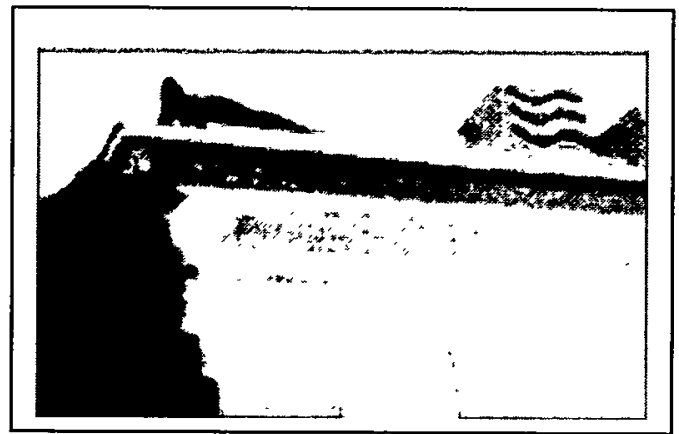

The stucco soffit connects directly to the plywood roof sheathing completing the house's air flow retarder.

The DOE Role

In 1991, DOE began providing funding to Integrated Building and Construction Solutions (IBACOS), a Pittsburgh-based design firm, for their development of a systems engineering approach to new home construction. Working in concert with builders, contractors, and materials and equipment suppliers, IBACOS designed pilot homes for communities in Pennsylvania, Texas, and California. These initial prototypes realized 30 to 45 percent energy savings over the builders' standard performance at construction costs from $\$ 20$ less to $\$ 20$ more per house. Based on the success and promise of these early efforts, DOE launched the Building America Program in 1993 to encourage the development of additional public-private partnerships to pursue systems engineering concepts in production-scale building throughout the United States.

Through a competitive process, three consortia (Building Science Consortium, the Hickory Consortium, and the Consortium for Advanced Residential Buildings) joined IBACOS to create the program's four Building America teams. Consortia members work together to design, build, and test prototype homes. DOE provides cost-sharing funds to the consortia for staffing and project design, builder/contractor training, and monitoring activities. The National Renewable Energy Laboratory (NREL) provides field support to the consortia, including project evaluation, independent testing, and outreach to the building industry. No DOE funds are used for construction costs, building materials, or equipment.

\section{Benefits and Costs}

DOE invested $\$ 13.6$ million in R\&D and technical assistance through the Building America Program from 1995 through 1998. Current funding for the program is $\$ 5$ million per year. Cost sharing on the part of each team has greatly exceeded the minimum goal of $50 \%$ for the program. The membership of each 
team continues to grow as additional building, finance, and appliance partners become involved. The four teams currently include 80 companies.

Building America designs and technologies are being adopted by builders and incorporated into a growing number of new homes around the country. Building America's members construct over 30,000 homes in the United States each year. In addition, subcontractors working on Building America projects are taking the new techniques and expertise to other projects. Building codes are being reevaluated and updated to accept innovations introduced by the Building America teams, and new products are being commercialized as a result of the Building America program. Some of the specific accomplishments of each team are described below.

Building Science Consortium. This team is working in 12 states to design cost-effective, energyefficient single-family homes for each of four U.S. climate types. Builder members have adopted Building America concepts for the construction of approximately 2500 homes in 17 communities, more than 250 of which have been completed. Re-engineering and design is underway in 8 other locations. Results from a year-long testing program at Prairie Crossing in Grayslake, Illinois, confirm that their techniques allow for 50 to 60 percent energy savings over the regional standard construction practice at a small incremental cost over that builder's standard practice.

Consortium for Advanced Residential Buildings. The CARB team begins each project by creating a completely new design for each prototype based on an existing plan of the builder partner. This initial stage formulates architectural solutions that lend themselves to efficient mechanical and structural systems. Using this integrated approach, the CARB team has completed four prototypes that have used significantly fewer resources to build, while still achieving energy savings of $20 \%$ to $35 \%$ over their accompanying control houses. If built on a production scale, which is planned for at least one prototype, construction cost savings can be achieved.

Hickory Consortium. This team is working with multi-family housing including factory-built modular housing. In 1998, it completed work on the Cambridge Cohousing development in Cambridge, Massachusetts. This 41-unit planned neighborhood is demonstrating energy savings of 50 percent over the Massachusetts Energy Code (prior to adoption of the 1995 Model Energy Code). Hickory has also completed the engineering and specifications for a 61-unit high rise apartment complex in Boston and two prototype duplex homes. Plans are underway to integrate energy desing features in an additional 60-unit multi-family complex in Boston.

IBACOS. Since joining efforts with DOE in 1991, IBACOS has conducted successful design and construction partnerships in 10 states to deliver single-family homes of higher efficiency, quality and affordability. IBACOS partners with innovative builders and developers in a commitment to continually challenge and improve building practices. To date, working relations with 18 builders and developers have resulted in the construction of 268 homes built to the higher standards of Building America. In addition, six Pilot Homes have been built and tested to expand field and technical understanding of advanced building system technologies into the mainstream marketplace. Past performance achievements include 30 to $60 \%$ utility savings to the homeowner annually with no additional cost to the builder.

\begin{tabular}{|c|}
\hline For More Information \\
\hline http://www.eren.doe.gov/buildings/building america/
\end{tabular}

http://www.eren.doe.gov/buildings/building_america/

Farrar, S., Hancock, E. and Anderson. R. 1998. "Systems Interactions and Energy Savings in a Hot Dry Climate" Proceedings of the ACEEE 1998 Summer Study on Energy Efficiency in Buildings, 1:79-92. 


\section{Greening Four Times Square}

Four Times Square-a 48-story skyscraper and the first major construction project in Manhattan in ten years - is one of the most environmentally and technologically advanced buildings in the nation, and is being called the first environmental office building in New York. The Four Times Square project is one of more than 8,500 projects that have been supported by grants from DOE's State Energy Program.

The Durst Organization set out to build an environmentally responsible or "green" 1.6 million square foot speculative office building which would be the first project of its size to adopt standards for energy efficiency, indoor ecology, sustainable materials, and responsible construction, operations, and maintenance procedures. The developers are confident that their next building project will surpass even the benchmarks set by Four Times Square.

\section{The DOE Role}

The developer's determination to build "green" drew the interest and assistance of many energy experts. DOE's role was carried out through the New York State Energy Research \& Development Authority (NYSERDA), one of many U.S. state energy offices that act as catalysts for public-private partnerships to encourage deployment of energy-efficient technologies. A NYSERDA grant, funded by DOE's State Energy Program, supported the developer's use of the advanced energy analysis program - DOE-2. The program's analyses were used as a primary basis for the selection of all HVAC and lighting systems and exterior cladding materials and techniques.

Building designers aimed to maximize daylight; install energy-efficient, lowemission, CFC-free chillers for the HVAC system; use fuel cells and photovoltaic cells to generate 3500 megawatt hours of electricity on site per year; and provide superior indoor air quality in the office spaces. Their biggest constraints were economic factors and the contractual requirement to allow tenants to determine how their interior spaces would be designed. The architects found that the hard economic analyses from DOE-2 runs were critical in gaining tenants' favor for energy-efficiency measures by showing their financial benefits.

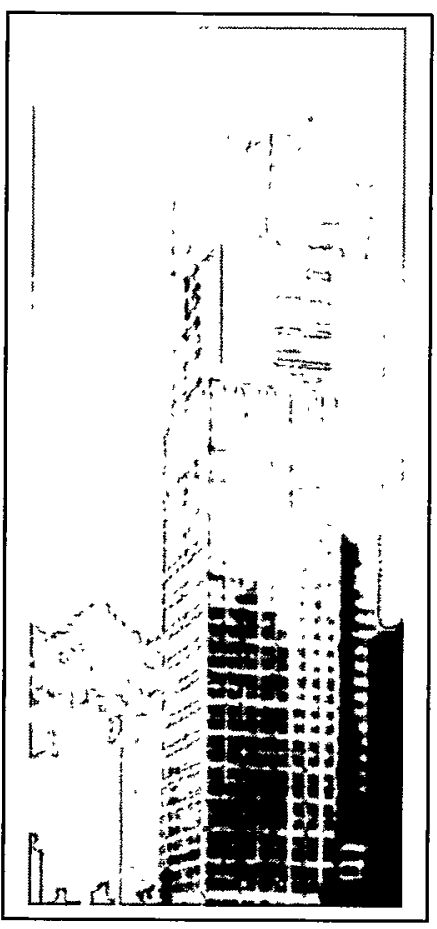

\section{Costs and Benefits}

\section{The Four Time Square Project.}

The energy-efficient technologies employed in the skyscraper are expected to reduce operational costs by 10 to $15 \%$ relative to a comparable project. Overall payback for the incremental costs in making the skyscraper energy efficient is expected to be between 6 and 10 years. The economics of some of the individual technologies are discussed below.

- The high transmittance glass selected for the skyscraper's windows, which take up 7 feet of a 9-foot ceiling height, could effectively provide daylight to $25 \%$ of a given floor. Payback for the glass is approximately 14 months. 
- Natural gas-fired CFC-free absorption chillers are extremely efficient with a payback of approximately three years. They avoid the substantial energy waste normally lost in transmission from electric power plants to buildings.

- The two on-site fuel cells generate about 3,500 megawatt hours per year. Fuel cells are large natural gas conversion systems that generate extremely clean power via a chemical reaction. No combustion is involved and the byproducts are hot water and $\mathrm{CO}_{2}$. Depending upon the price of natural gas, payback could be less than 10 years.

- Photovoltaic (PV) cells are being used to a limited degree to generate energy as an on-site demonstration. The PVs are integrated into the "spandels" on the building-the area of the façade between the top of one window and the bottom of another. A "thin-film" type of photovoltaic was selected because the paybacks were far better than with the crystalline type. The PV cells were laminated onto tempered glass and structurally glazed with the façade. The peak output of the installation is about $15 \mathrm{~kW}$, approximately equaling the electricity needs of five or six suburban homes.

\section{The State Energy Program.}

Since 1996, NYSERDA has used $\$ 305,000$ of funding from DOE's State Energy Program to provide assistance for projects valued at over $\$ 1$ billion. Studies show that if NYSERDA recommendations are implemented the energy efficiency of these buildings will exceed the requirements of the New York State Energy Code by an average of $34 \%$ with an increase of less than $1 \%$ in construction cost and a simple payback of 3.5 years.

State energy offices nationwide have leveraged $\$ 4$ in non-federal funding for each dollar of funding from DOE's State Energy Program, generating dramatic improvements in energy efficiency as well as economic and environmental benefits since the program's inception in 1976. DOE's State Energy Program has helped over 69,000 school and hospital buildings become more energy efficient, saving hundreds of millions of dollars in annual heating costs and enabling these institutions to make better use of taxpayer dollars.

\section{For More Information}

Lessons Learned Four Times Square: An Environmental Information and Resource Guide for the Commercial and Real Estate Industry. Author: Pamela Lippe, et al. Date: 5/97. Publisher: Earth Day New York, 205 East 42nd Street, Suite 1314, NY, NY 10017. Phone: 212-922-0048, Fax: 212-922-1936.

http://home.dti.net/earthday/Building.html 


\section{Federal Energy Management Program On Target to Meet Goals}

The Department of Energy's Federal Energy Management Program (FEMP), as mandated by Congress, leads the effort to reduce energy consumption and related costs within the federal government. FEMP's varied technical and finance assistance programs aid agencies in identifying, financing, and implementing projects that cost-effectively incorporate energy efficiency, water conservation, and renewable energy technologies into federal facilities.

Between 1985 and 1997 the efforts of FEMP and other federal agencies have reduced energy consumption in government buildings by $17 \%$ in terms of Btu per square foot-reaching more than halfway to the federal goal of a $30 \%$ reduction by 2005 . By promoting responsible energy management and institutionalizing energy efficiency as a good business practice, FEMP is contributing to the nation's economic vitality and productivity while providing the environmental benefits of reduced fossil fuel consumption.

\section{The DOE Role}

The Energy Policy Act of 1992 and Executive Order 12902 require federal agencies to reduce the energy use of buildings and facilities by 20 and $30 \%$ in the years 2000 and 2005 respectively, compared to 1985 energy intensities. FEMP focuses the majority of its efforts on reaching these goals in the government's approximately 500,000 buildings.

FEMP has created and implemented a range of tools to aid federal agencies' energy savings activities. One of these, the Energy Savings Performance Contract (ESPC), provides a type of contract through which agencies use private capital to provide energy efficiency services and then pay for these services through energy cost savings. Newly introduced regional and technology-specific Super ESPCs make energy efficiency contracting even more efficient. Facility improvements made under these Super ESPCs are forecast to cut federal energy costs by more than $\$ 11$ billion over the life of the projects. FEMP is currently working with agencies to develop more than 150 ESPC projects.

In addition to its assistance with project financing options, FEMP also develops analytical tools and information to assist federal agencies with identifying and selecting cost-effective energy projects and products. These tools include on-site energy and water audits, evaluating project proposals, providing up-front engineering and design support, and assisting in the measurement and verification of projects' actual energy savings.

FEMP's training and outreach programs have reached almost 18,000 federal energy managers since 1993, including more than 4,700 in fiscal year 1999. A recent survey documented that FEMP training workshops help attendees implement energy efficiency projects. After attending FEMP workshops, 98\% of the

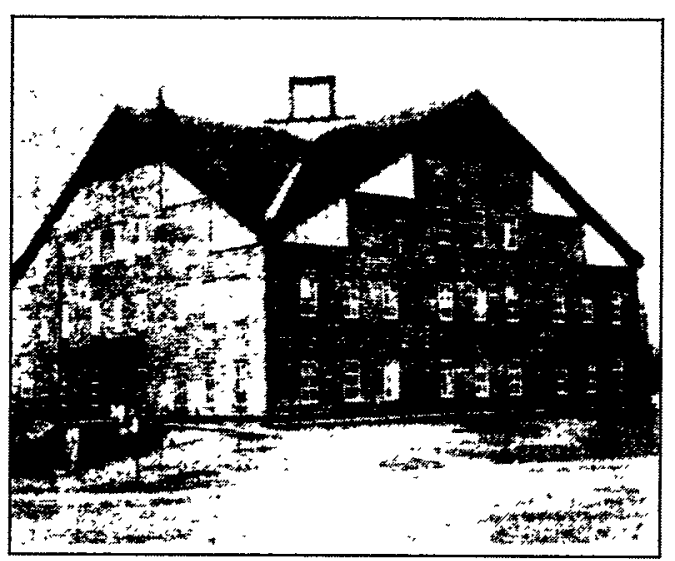

A building slated for energy efficiency upgrades at the USCG base in Kodiak, Alaska. attendees have implemented energy efficiency projects, including those who were either unaware of or still seeking information about energy efficient technologies prior to their workshop attendance. While there are many factors leading to project 
implementation, this survey demonstrates a high correlation between attending FEMP workshops and the execution of energy-efficiency projects.

\section{Benefits and Costs}

According to preliminary 1998 data reported annually by all federal agencies, DOE FEMP and federal energy management programs in other federal agencies have accomplished the following:

- Reduced the government's primary energy consumption for buildings, mobility, and industrial operations by 351.2 trillion Btu, or 19\%, between 1985 and 1998 .

- Reduced energy costs by $\$ 6.5$ billion inflation-adjusted dollars.

- Avoided the atmospheric release of carbon from buildings and facilities-related energy consumption by 2.1 million metric tons.

- Contributed significantly to a gross reduction in building energy costs of more than $\$ 2.2$ billion compared to 1985.

- Assisted the federal government in reducing its use of petroleum-based fuels for all purposes by $35.9 \%$, and for use in buildings by $63.7 \%$, since 1985 .

DOE FEMP has served as a catalyst for DOE and other federal energy-savings activities on a relatively modest budget. In FY1999, DOE FEMP spent just \$23.8 million. From 1985 to 1999, FEMP has spent $\$ 142.1$ million inflation-adjusted dollars.

The activities of FEMP and other federal energy management programs benefit not only the government's bottom line, but also the nation's economic vitality. To meet the $30 \%$ energy reduction goal by 2005 will require the investment of nearly $\$ 5$ billion to repair or replace aging equipment in buildings. This investment will result in lower energy costs and more efficient operations for government agencies. These dollar savings may be used to invest in other federal activities and to reduce the federal deficit.

Generally, each dollar invested in energy efficiency results in savings of four dollars over a project's life, divided equally between the government and the private company if financed by the private company. This level of investment will create approximately $15,000^{\circ}$ new jobs, reducing unemployment and contributing to the nation's economic vitality. Energy-efficiency and renewable-energy projects are an untapped economic resource and federal facilities comprise vast resource fields for job-creating economic activity in the construction, engineering, manufacturing, and financing industries.

Improving the energy efficiency of federal facilities also bestows environmental benefits on the nation: reduced energy demand lessens the atmospheric pollution emitted when electricity is generated; reduced water consumption lessens the stresses placed on aquatic ecosystems; and use of renewable energy technologies can completely eliminate point-of-generation pollution.

\section{For More Information}

For more information on FEMP's energy-related activities, please visit their website at :

http://www.eren.doe.gov/femp 


\section{Renewable Energy Technologies in Federal Facilities}

With the goals of reducing energy consumption, showcasing renewable energy technologies, and enhancing the experience of visitors, DOE's Federal Energy Management Program (FEMP) and Office of Power Technologies (OPT) have teamed with the National Park Service (NPS) to install solar technologies at sites across the nation. This partnership provides park service facilities with energy at relatively low cost and with minimal adverse impacts on the environment. As Gary Candelaria, Pinnacles National Monument Superintendent, attests: "The PV [photovoltaic] system does everything we designed it to do, and it costs a fraction of what we used to pay each month to operate and maintain the diesel generators it replaces."

\section{The DOE Role}

DOE FEMP employed a broad range of resources to ensure the success of the renewable-energy installations at Pinnacles and Chickasaw national parks in California and Oklahoma. In 1994, DOE's Sandia National Laboratories surveyed existing NPS photovoltaic systems, analyzed the site's electrical loads, conducted a solar resources assessment, summarized the power options available, recommended installation of a hybrid photovoltaic system, and then worked with NPS staff to develop an installation and operation plan. Sandia's technical assistance was funded by DOE at a cost of $\$ 60,000$. At Chickasaw, FEMP liaisons from the National Renewable Energy Laboratory (NREL) conducted the initial feasibility study, prepared project specifications, reviewed the evolving design, and conducted final inspections on the completed system. FEMP provided $\$ 10,000$ to enlist the aid of the NREL liaisons.

FEMP works within the federal government to encourage the use of renewable technologies by providing technical support and creative alternative-financing mechanisms that allow economically sound installation of renewable energy technologies. The benefits of this work are seen in the energy savings realized at the Pinnacles National Monument and Chickasaw National Recreation Area, described below. These two are only a small sample of the savings that are being, or could be, realized in other locales. In FY 1998 FEMP funded 30 renewable-energy projects out of more than 75 proposals. Total funding for the projects was $\$ 1.9$ million. All of these projects will pay for themselves in less than 10 years.

\section{Benefits and Costs}

\section{Benefits at Pinnacles National Monument.}

Pinnacles National Monument's decision to "go solar" was prompted by quality of life issues as well as cost. By replacing diesel generators with a hybrid photovoltaic/propane generator system, the NPS significantly reduced noise and pollutant emissions. These modifications have substantially improved the visitor experience. The installed hybrid system consists of a $9.6-\mathrm{kW}$ photovoltaic array, a 200-kWh bank of flooded lead-acid batteries, a $20-\mathrm{kW}$ propanepowered generator, and a modular inverter configuration.

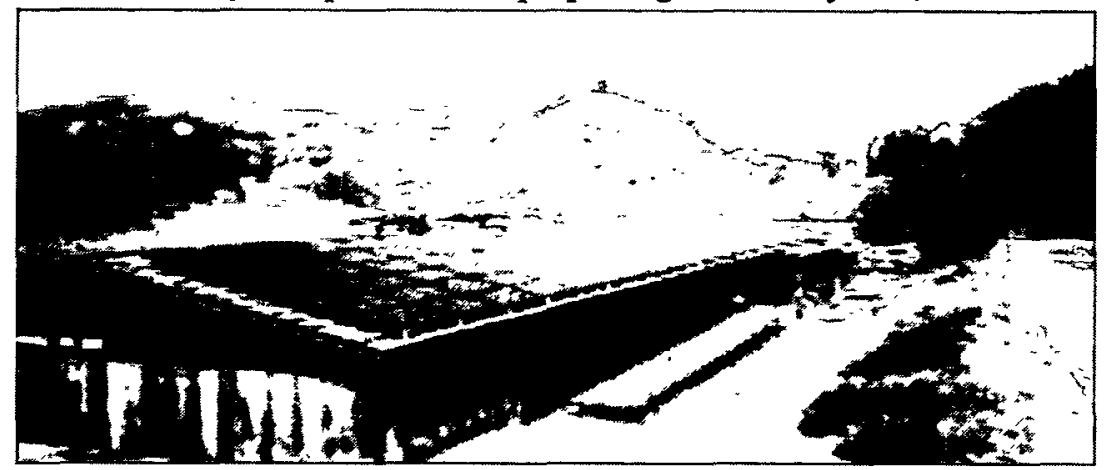


The new system provides $100 \%$ of site power requirements from May through September and $30 \%$ during the winter months. Use of the photovoltaic array will reduce propane consumption by 162,000 gallons over 20 years, cutting annual fuel costs from $\$ 12,000$ to $\$ 2,000$, an $83 \%$ reduction. The system, including all energy-efficiency measures and installation, cost $\$ 150,000$. It has a simple payback period of seven years, and is projected to save the park service $\$ 16,000$ to $\$ 18,000$ per year. The hybrid system also reduces atmospheric emissions: 135 tons of $\mathrm{CO}_{2}, 6,875.8$ pounds of $\mathrm{NO}_{\mathrm{x}}$, and 342.9 pounds of $\mathrm{SO}_{2}$ less than the emissions of the diesel generator sets.

\section{Benefits in Chickasaw, Oklahoma National Recreation Area.}

In an effort to lessen adverse effects on the local environment and save money at the same time, the

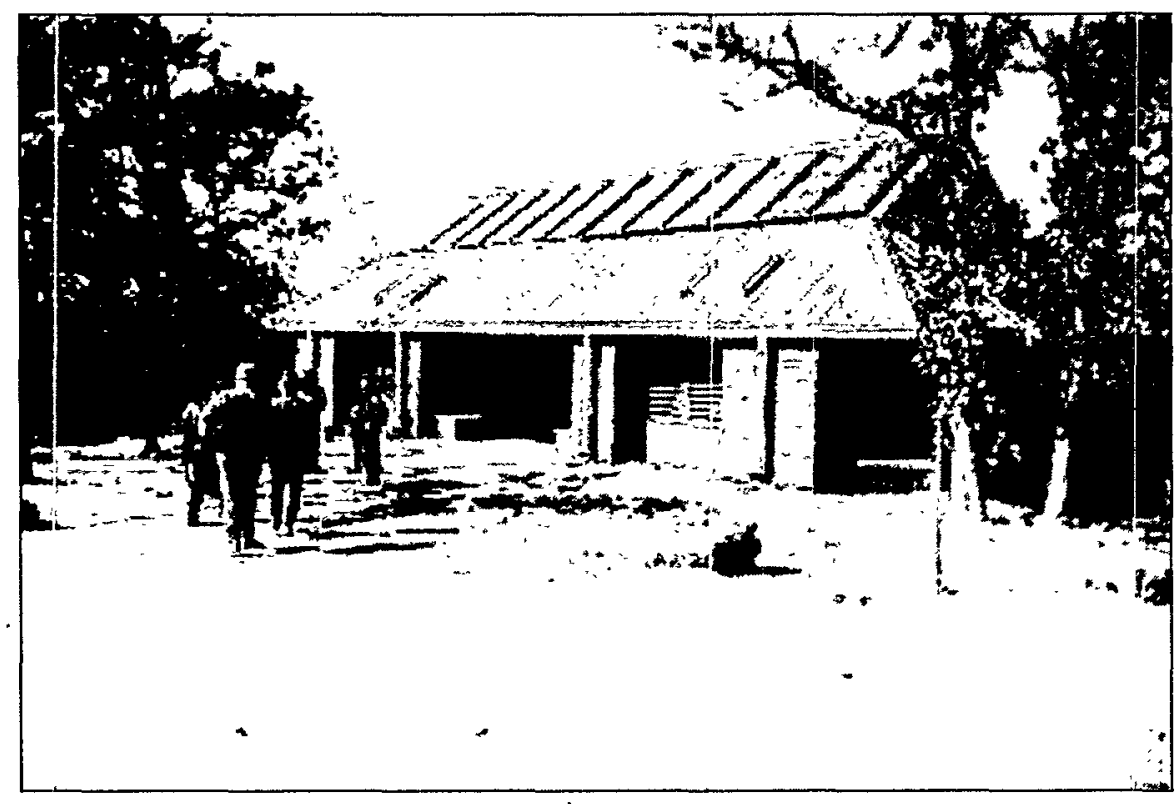

amount of available sunlight, increasing overall system efficiency.
National Park Service installed solar collectors at three comfort stations within Chickasaw to provide solar-heated water for showering, lavatories, and cleaning. The systems, totaling 872 square feet of solar collectors, produce about $37,000 \mathrm{kWh}$ of solar heat annually and provide $95^{\circ} \mathrm{F}$ water year-round with 93 to $96 \%$ reliability. In addition to the systems' technical advantages, user demand patterns at the park closely follow the

These systems, designed to save energy, reduce emissions, and lower the park service's operating and maintenance cost burden, cost $\$ 31,700$ to install, and have a simple payback period of nine years. The systems reduce purchased energy consumption by $36,982 \mathrm{kWh}$ or 126 million Btu per year, saving $\$ 2,219$. In addition to the three installed systems, 20 more are planned for the site.

\section{For More Information}

For information on work conducted at Pinnacles National Monument, please visit:

http://www.eren.doe.gov/femp/techassist/530_pinnacles.html.

For information on the Chickasaw NRA project, please visit:

http://www.eren.doe.gov/femp/newsevents/femp_focus/may97_park.html 


\section{FEMP Lamp Swap}

In January 1998, the Federal Energy Management Program (FEMP) coordinated a program at Bolling Air Force Base in Maryland in which on-base housing residents traded in halogen torchiere lamps for torchieres lighted by compact fluorescent lamps (CFLs), which were provided at no cost by DOE. The drive behind the swap was two-fold: decrease energy consumption by switching to energy-efficient CFLs, and increase the safety of on-base housing by removing the type of halogen torchieres that have been implicated in 260 fires and 12 deaths in the United States.

If one million advanced CFL torchieres were purchased by consumers instead of halogen torchieres, the estimated energy cost savings would be $\$ 27.4$ million annually (343 million $\mathrm{kWh}$ energy savings) or $\$ 192$ million (2.4 billion $\mathrm{kWh}$ ) over the seven-year life of the lamps. Estimates are that $200,000 \mathrm{CFL}$ torchieres were sold in 1998.

\section{The DOE Role}

FEMP leads the effort to reduce energy use and costs in the federal government. Of all the residential property owned by the government, $90 \%$ is military housing. The Bolling AFB torchiere swap was coordinated by DOE, Bolling leadership, and the Department of Defense (DoD), in partnership with DOE's Lawrence Berkeley National Laboratory and the Alliance to Save Energy, a non-profit organization. DOE invested roughly $\$ 300,000$ between 1995 and 1997 to research and develop the technology and spent $\$ 7,500$ (150 lamps at $\$ 50$ each) to buy the CFL torchieres provided at no charge to residents. The Bolling lamp swap has the potential to save 1.2 billion Btu-a savings of nearly $\$ 29,000$ over the lamps' seven-year lifespans.

\section{Benefits and Costs}

Payback for CFL Torchiero over 1 CFL Lamp Life

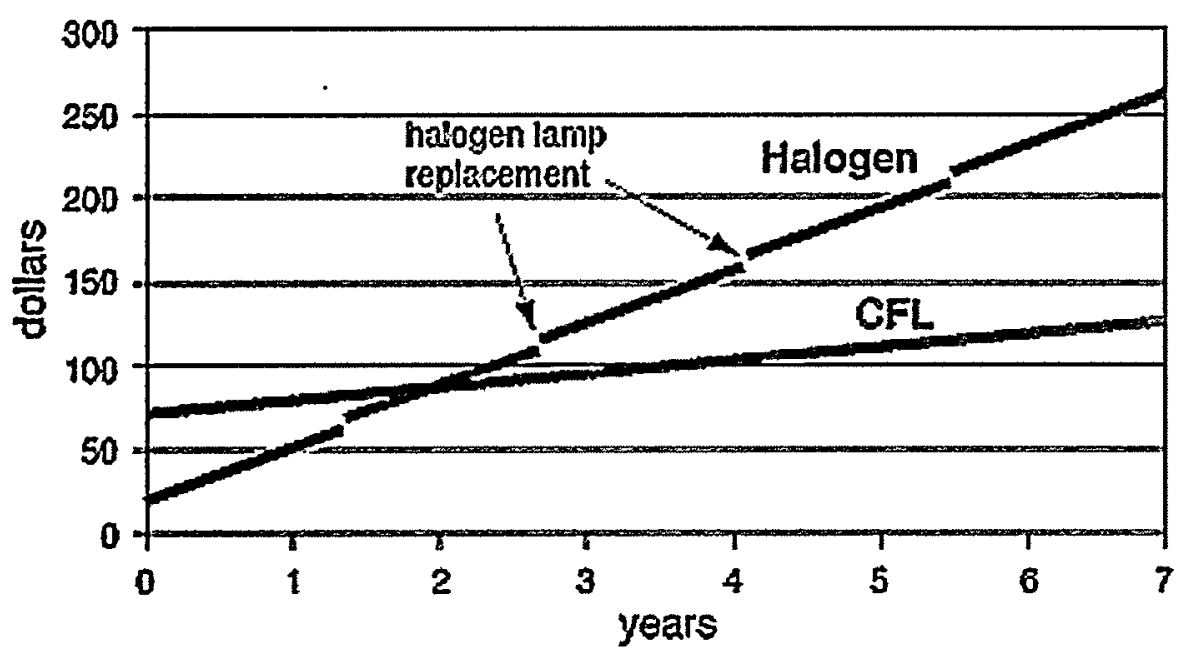

Compact fluorescent torchieres produce $25 \%$ more light than halogen torchiere-style lamps while using just $20 \%$ of the electricity. Despite their higher initial cost (CFL torchieres can cost $\$ 70$ compared to $\$ 20$ for halogen torchieres), the more efficient CFLs have a lifespan five times that of halogen lamps, so each lamp can save $\$ 192$ in energy costs over its lifetime.

The energy-efficiency of CFLs provides safety benefits to the consumer as well. Because they consume significantly less electricity, the bulb temperature doesn't exceed much more than $100^{\circ} \mathrm{F}$. Halogen bulb 
temperatures can reach over $1,000^{\circ} \mathrm{F}$. These extreme temperatures can cause fabrics, such as drapes, to ignite, and have been implicated in starting 260 fires and causing 12 deaths in the United States alone. Just one week before implementing the swap, a halogen lamp was implicated in a fire at Bolling AFB. No one was injured in the incident.

Gene Foley, lighting and appliances program manager at the Alliance To Save Energy, said, "These new fixtures will do more than light the homes at Bolling. They will save tax dollars, cut pollution, and ensure the safety of those who use them."

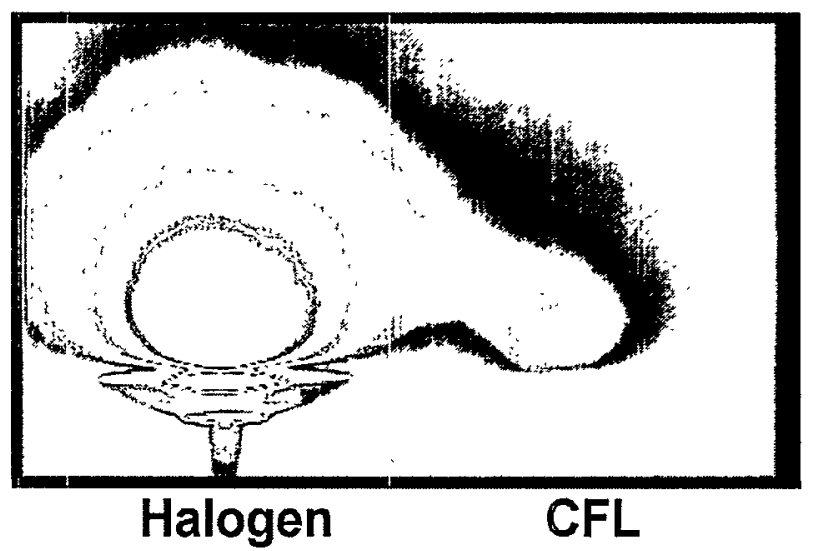

\section{For More Information}

For more data and information on halogen torchieres, please visit:

http://eetd.lbl.gov/BTP/torchiere.html 


\section{FEMP Helps Government Agencies to Buy Energy-Efficient Products}

The federal government spends an estimated $\$ 12$ billion per year purchasing energy-related products, and $\$ 8$ billion a year on energy itself. Executive Order 13123, issued in June 1999, aims to reduce the costs and environmental impacts of federal energy usage by cutting energy consumption by $35 \%$ by 2010 . The Federal Energy Management Program (FEMP) has an array of programs designed to meet this goal. One activity alone-purchasing and using energy-efficient equipment-has the potential to meet $20 \%$ of the year 2010 energy-savings goals. FEMP spent approximately $\$ 600,000$ in FY1999 to provide government purchasers with reliable information on the energy efficiency of commonly purchased products, and to train purchasers to identify energy-efficient products in a range of categories.

\section{The DOE Role}

Executive Order 13123 requires federal agencies to, where cost-effective, purchase "ENERGY STAR® and other energy efficient products. Where ENERGY STAR® labels are not yet available, agencies shall select products that are in the upper $25 \%$ of energy efficiency as designated by FEMP." Twenty-two agencies signed the Procurement Challenge in 1995. FEMP has the lead role in advising agencies of these provisions and assists agencies in identifying energy-efficient products through publication of Product Energy Efficiency Recommendations. The 33 Recommendations available currently range from large electric chillers to light bulbs. The Recommendations

- identify the efficiency level that complies with the upper $25 \%$ requirement,

- identify federal supply sources that offer efficient products,

- suggest ways for buyers to identify efficient products when buying from commercial sources, and

- present cost-effectiveness examples for products.

The Recommendations are a popular and effective tool for energy managers. About 2,700 Recommendations binders have been distributed since the first printing in 1997, about two-thirds of them to federal employees. Almost half of the recipients responding to a November 1998 customer survey reported that they have implemented energy- or water-saving projects during the past two years, and that their decisions were influenced in part by the Recommendations.

FEMP is also an active partner with the U.S. Environmental Protection Agency (EPA) in the ENERGY STAR $\circledast$ labeling program, working with EPA to improve the efficiency of products ranging from office equipment to electrical transformers. By influencing purchasers to think in terms of energy efficiency, the government's bulk purchasing power can send a strong signal to manufacturers to produce more efficient products at a more competitive cost, thus making them more attractive to the private sector.

\section{Benefits and Costs}

The Army Corps of Engineers and the Navy have taken a comprehensive approach to instituting FEMP's Recommend-ations. Each of these agencies has "hard-wired" several of FEMP's recommended levels into their guide specifications for new construction and major renovation work. The guide specifications are the template used by architecture and engineering firms to develop actual project specifications. Among the products affected are electric chillers, distribution transformers, motors, and fluorescent tube lighting. The Army Corps and Navy are responsible for the majority of the roughly $\$ 6$ billion per year in DoD construction. 
The success of the Federal Procurement Challenge is based on the aggregate savings of many individual purchasing decisions. For example, incorporating the Recommendations into their business-as-usual practices, federal agencies can realize cost and energy benefits from merely replacing conventional fluorescent lights at the end of their lives with energy-saving ballasts

\begin{tabular}{|l|l|l|l|}
\hline Fluorescent Tube Lamp Cost-Effectiveness Example \\
\hline Performance & Base Model & $\begin{array}{l}\text { Recommended } \\
\text { Level }\end{array}$ & Best Available \\
\hline Lamp and Ballast Type & $\begin{array}{l}\text { T12,34 watts, } \\
\text { magnetic } \\
\text { ballast }\end{array}$ & $\begin{array}{l}\text { T8, 32 watts, } \\
\text { electronic } \\
\text { ballast }\end{array}$ & $\begin{array}{l}\text { T8 32 watts, } \\
\text { electronic } \\
\text { ballast }\end{array}$ \\
\hline $\begin{array}{l}\text { Actual Light Output, } \\
\text { with Ballast }\end{array}$ & 4738 lumens & 5018 lumens & 5256 lumens \\
\hline Input Power & 82 watts & 62 watts & 57 watts \\
\hline Annual Energy Usage & $295 \mathrm{kWh}$ & $223 \mathrm{kWh}$ & $205 \mathrm{kWh}$ \\
\hline Annual Energy Cost & $\$ 17.70$ & $\$ 13.40$ & $\$ 12.30$ \\
\hline $\begin{array}{l}\text { Annual Energy Cost } \\
\text { Savings - Lamps \& } \\
\text { Ballast }\end{array}$ & - & $\$ 4.30$ & $\$ 5.40$ \\
\hline
\end{tabular}
and bulbs. These benefits are considerable when applied on the scale of an entire building, and even greater when one considers the numbers of fluorescent lamps in government buildings across the nation. Similar savings are achievable for the range of items documented in FEMP's Recommendations.

\section{For More Information}

For more information regarding FEMP's Procurement Challenge, please see:

$\mathrm{http} / / / \mathrm{www} . e r e n . d o e . g o v / f e m p / p r o c u r e m e n t / c h a l l e n g e . h t m l$ 


\section{Federal Fleet Alternative Fuel Acquisition Program}

One of the goals of the Energy Policy Act of 1992 (EPACT) is to displace $10 \%$ of petroleum fuel used in the transportation sector with replacement fuels (e.g., natural gas) by the year 2000. Successful introduction and commercialization of alternative fuel vehicles (AFVs) and advanced technology vehicles with significantly improved fuel economy are necessary to achieve reductions in oil consumption and environmental emissions from the transportation sector. The U.S. Department of Energy (DOE) is making steady progress in carrying out the provisions of EPACT.

The DOE and other Federal agencies have been working to promote the purchase and use of AFVs in accordance with Title III of EPACT. In addition to providing reductions in U.S. petroleum use, the acquisition and use of AFVs by Federal agencies will help demonstrate the practicality of alternative fuel technologies on a substantial scale. These acquisitions are also designed to accelerate the development of an alternative fuel refueling infrastructure. Over time, operation of AFV's by Federal and other regulated fleets should provide the critical mass necessary to motivate U.S. industry to product alternative fuels and vehicles at competitive prices.

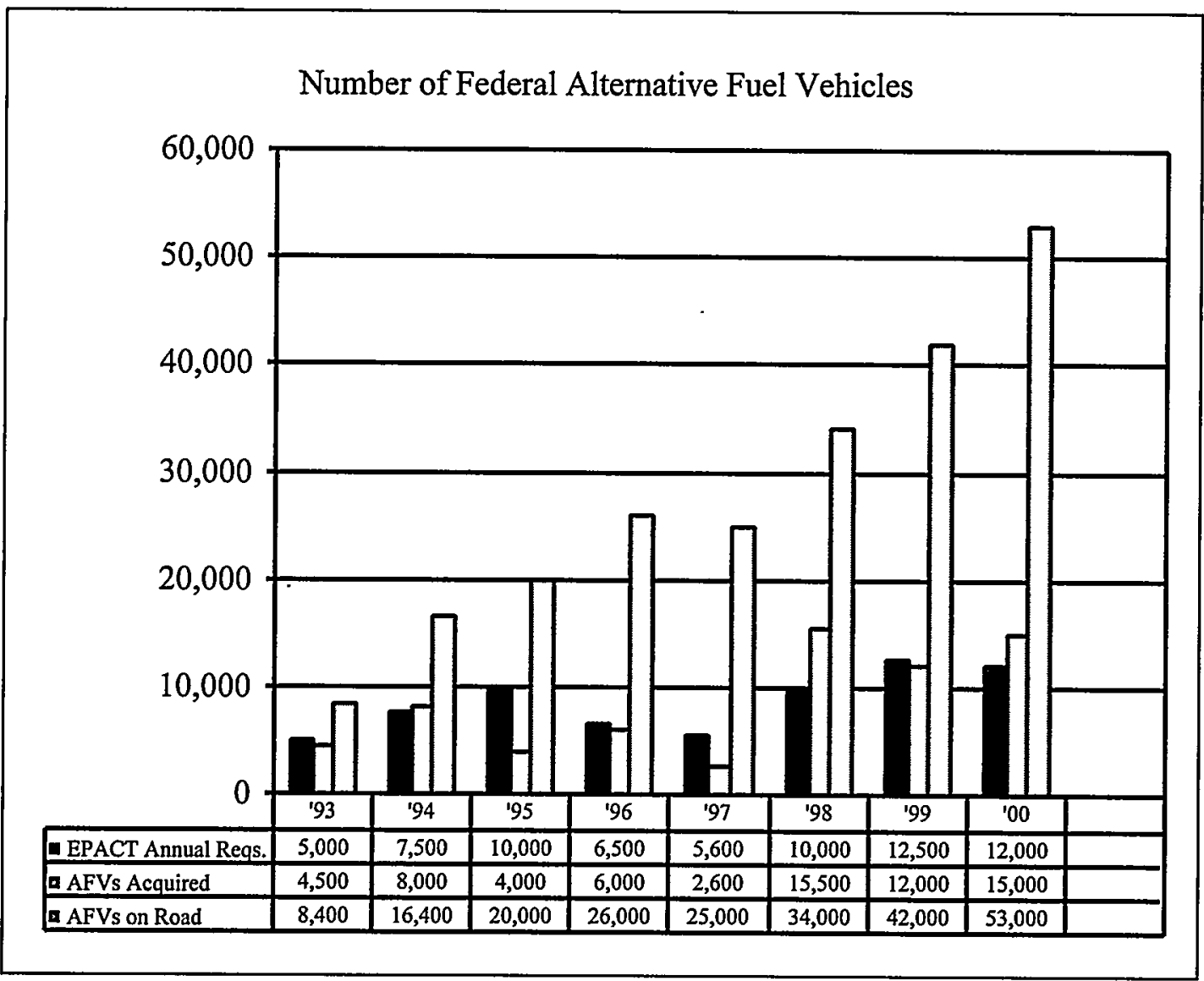

The potential for using replacement fuels in the United States is very high. Analysis indicates that currently authorized Federal, state, and local alternative fuel programs alone could displace roughly $3 \%$ of gasoline fuel use projected for 2010. In addition, current estimates suggest that the entire transportation market could support replacement of as much as 30 to $38 \%$ of the light-duty vehicle fuels by the year 2010. 
The DOE AFV deployment program is divided into four complementary program areas: Clean Cities, Testing and Evaluation, EPACT Replacement Fuels Program, and Advanced Vehicle Competitions. The Federal Fleet AFV Acquisition Program is included in the Testing and Evaluation program area. Total spending in this account was approximately $\$ 3$ million for both FY 1998 and FY 1999, of which nearly $\$ 1.4$ million was spent on the Federal Fleet AFV program each year. This includes $\$ 1$ million a year to buy-down $50 \%$ of the incremental cost of electric vehicles procured by Federal agencies, as directed in Executive Order 13031 of 1996 . The incremental cost of acquiring other AFVs was borne by the participating Federal Agency.

\section{Benefits and Costs}

Selected accomplishments to date are summarized below.

-Promoted the acquisition of more than 34,000 AFVs by Federal fleets - nearly $80 \%$ of the EPACT requirement of 44,600 through fiscal year 1998 . 52\% of the AFVs are compressed natural gas vehicles and $47 \%$ are $M-85$ or E- 85 vehicles.

-Used 4.2 million gasoline-gallon-equivalents of alternative fuels in Federal fleets in 1997.

-Initiated a pilot program in Washington, D.C. to loan electric vehicles (EVs) to Federal fleets for 30 days at no cost and with no commitment. DOE pays for the loaned EVs to give Federal fleet managers the opportunity to test the technology and encourage them to acquire EVs.

-Expanded EV Loaner Program started in Washington, D.C. to include Atlanta, Boston, Los Angeles, San Diego, and Norfolk/Richmond/Northern Virginia.

-Established an EV Incremental Cost Buy-Down Program for Federal fleets acquiring EVs, which, in conjunction with the EV Loaner Program, has resulted in the placement of 140 EVs by Federal fleets for FY 1999.

\section{Future Activites}

- Establishing the Federal Fleet Focus Cities Program to support alternative fuel infrastructure through the coordinated, concentrated acquisition of Federal AFVs and use of alternative fuel in Federal AFVs in six designated cities.

- Assisting in the procurement of more than 10,000 AFVs for Federal fleets in FY 1999.

- Supporting the procurement of 12,500 AFVs annually for Federal fleets in FY 2000 and beyond.

\section{For More Information:}

http://www.afdc.doe.gov

National Alternative Fuels Hotline - 1-800-423-1DOE 


\section{Million Solar Roofs Initiative}

Million Solar Roofs (MSRI) is an initiative to install solar energy systems on one million U.S. buildings by 2010. MSRI includes two types of solar energy technology - photovoltaics (PV) that produce electricity from sunlight, and solar thermal systems that produce heat for domestic hot water, space heating or heating swimming pools.

\section{The DOE Role}

DOE leads this effort in partnership with financial institutions, the building industry, utilities, energy service companies, the solar energy industry, state and local governments, Federal agencies, and non-governmental organizations.

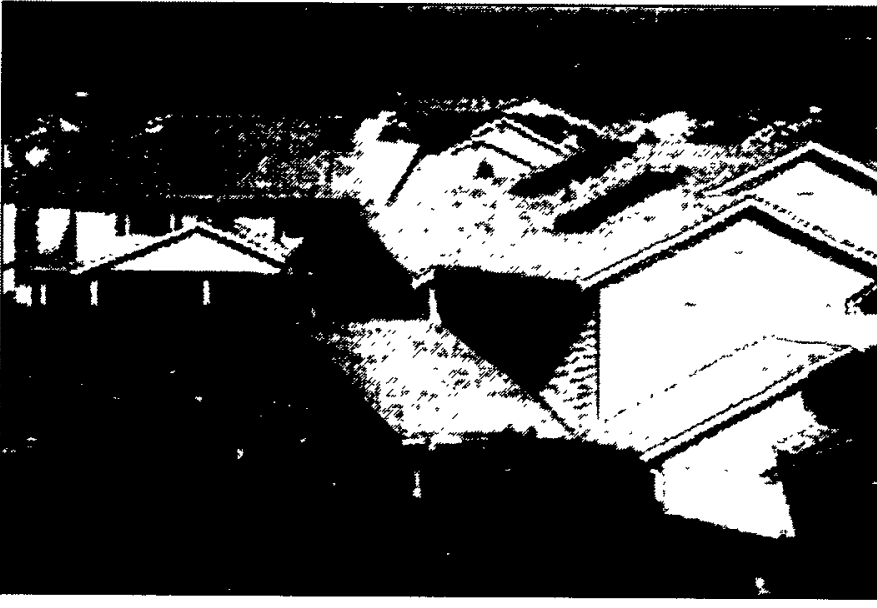

Solar hot water systems at the Navy's Moanalua Terrace family housing project in Hawaii. Hawaiian Electric Co., Inc NREL/PLX05573. Together they work to remove market barriers to solar energy use and develop and strengthen demand for solar energy products and applications by developing new and existing financing options, leveraging resources, coordinating Federal agency support and sharing information with MSRI partners. DOE does not typically pay for the installation of solar systems under MSRI. The Department of Energy, through its network of Regional Offices (RO's) coordinates and provides support for the State and Local Partnerships in their area. This might include the following:

- Access to the Million Solar Roofs Small Grants program for State and Local Partnerships;

- Assistance in accessing low-cost loans, buy-down grants, and other financial assistance;

- Training, technical assistance, and information from DOE's RO's, program staff and national labs;

- Recognition on a national, regional, and local basis;

- Linkage with solar energy businesses, associations, and related industries that can provide assistance to local partnerships and others interested in solar energy applications.

\section{Benefits and Costs}

MSRI received $\$ 1.5$ million in funding in fiscal year 1999. Since the announcement of the Initiative in June, 1997, thirty-seven State and Local Partnerships have been formed across the country to develop local markets for solar energy systems. Together they have preliminary plans to install more than 900,000 solar energy systems on buildings by 2010 . At the end of 1998 , approximately 30,000 solar systems had been installed, including grid-connected and off-grid PV systems, solar hot water heaters and systems to heat swimming pools. A registry to track installed systems will become operational in 1999. A selection of additional accomplishments are highlighted below.

The U.S. Navy installed 136 solar hot water heaters in Phase II of the Moanalua Terrace Navy Family Housing project, in Oahu, Hawaii. The systems cost $\$ 235,000$ to install and save $\$ 34,000$ in energy costs 
annually. Over their lifetime these 136 systems will save $\$ 680,000$ in energy costs, 16.5 million pounds of $\mathrm{CO} 2,50,785$ pounds of $\mathrm{NO}_{x}$, and 54,550 pounds of $\mathrm{SO}_{2}$. Another 516 systems are being installed in Phases III and IV.

In June 1998, Wisconsin Public Service Corporation (WPSC) installed a $4 \mathrm{~kW}$, grid-connected, roof mounted PV system on East De Pere High School. The East De Pere PV system is the sixth to be installed on an area high school under their Wisconsin Public Service Community Foundation's SolarWise for Schools Program. In addition, WPSC received support through the Utility PhotoVoltaic Group directed TEAM-UP program. By using the PV system, 7,075 pounds of coal will not be used each year. This amounts to an annual reduction in emissions of 12,458 pounds of $\mathrm{CO}_{2}, 58$ pounds of $\mathrm{SO}_{2}, 67$ pounds of $\mathrm{NO}_{\mathrm{x}}$, and 2 pounds of particulates.

In 1998, the Western Area Power Administration installed a 38 kilowatt grid-connected PV system on its Elverta, California Maintenance Facility. The system generates 67,500 kilowatt hours of electricity per year and over its 20 year lifetime, the system will reduce emissions by 2,300 tons of $\mathrm{CO}_{2}, 8.7$ tons of $\mathrm{NO}_{x}$, and 16.4 tons of $\mathrm{SO}_{2}$.

\section{Potential Future Benefits}

One million solar energy systems could result in the sale of $2500 \mathrm{MW}$ of PV and solar water heating systems by 2010 , reduction of $\mathrm{CO}_{2}$ emissions by 3.5 million tons and the creation of 71,500 jobs.

\section{For More Information}

Visit the MSRI web site at http://www.MillionSolarRoofs.org 
Climate Challenge is a joint, voluntary effort of $\mathrm{DOE}$ and the electric utility industry to reduce, avoid, or sequester greenhouse gases. Utilities, in partnership with DOE, implement cost-effective activities that are specified in partnership accords, which are agreements between DOE and individual electric utilities.

Activities include efficiency improvements in end use, distribution, transmission, and generation; increased use of energy-efficient electrotechnologies; fuel switching to lower carbon fuels such as natural gas, nuclear, or renewable energy; transportation actions, including greater use of natural-gas-powered and electric vehicles; forestry actions; recovery of methane from landfills and coal seams; and the use of fly-ash as a cement substitute.

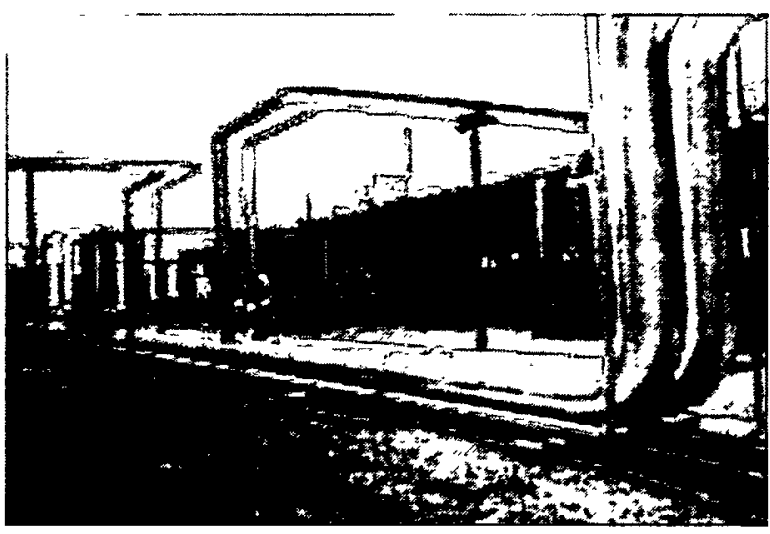

Sierra Pacific Power is purchasing power from this geothermal plant in Stillwater, Nevada. Geothermal plants in the U.S. generated 16.3 billion kilowatt hours of electricity in 1997. Sierra Pacific NREL/PIX07208

The DOE Role

DOE has been active in negotiating participation accords and reviewing existing accords. DOE also urged Department of Treasury officials to allow energy-conservation expenditures by utilities to be treated as business expenses. In April 1995, the Internal Revenue Service concluded that utility expenditures on demand-side management programs can be deducted from corporate income taxes as business expenses. DOE has also supported government/utility joint ventures in energy efficiency and renewable energy to increase market penetration and reduce costs. This includes supporting the Geothermal Heat Pump Consortium, the Utility PhotoVoltaic Group, and the Consortium for Energy Efficiency. DOE has also encouraged large purchases of efficient products by assisting buyers' groups through the Volume Purchase Program and coordinating alliances with major manufacturers, retailers, and utilities to promote and expand the market for high-efficiency commercial and residential clothes washers and dryers.

\section{Benefits and Costs}

Climate Challenge received a total of $\$ 0.95$ million in funding from fiscal years 1995 to 1999 . A total of 124 participation agreements have been signed, representing 641 utilities that together account for $71 \%$ of utility carbon emissions. Utility commitments carried out under Climate Challenge are estimated to result in the reduction of 47.6 million metric tons of carbon in 2000. The estimate is conservative, as it does not include reductions not yet quantified, nor the effects of nine industry-wide utility initiatives. Some examples of actions taken by utilities include the following:

The utility industry developed nine Climate Challenge initiatives for collective utility action. The initiatives include venture capital funds under the EnviroTech charter, with over $\$ 50$ million committed to accelerate commercialization of renewable-energy technology and energy-efficient electrotechnologies; the Earth Comfort Program, to increase annual sales of energy-efficient geothermal heat pumps from 
40,000 to 400,000 ; the Utility Forest Carbon Management Program, with over $\$ 2$ million committed to funding several domestic and international projects through the non-profit UtiliTree Carbon Company; and the International Utility Efficiency Partnerships, which is currently developing or evaluating carbonsaving projects in at least twelve countries.

In northern Nevada, Sierra Pacific Power is purchasing geothermal-generated power. By displacing generation from conventional coal units, these geothermal contract purchases reduce $\mathrm{CO}_{2}$ emissions by about 400,000 tons per year, with reductions in the year 2000 expected to be nearly 600,000 tons of $\mathrm{CO}_{2}$.

In the first market-based trade between electric utilities, Niagara Mohawk Power Corporation exchanged 1.75 million tons of $\mathrm{CO}_{2}$ reductions for Arizona Public Service Company's 25,000 tons of sulfur dioxide allowances. Niagara Mohawk donated the sulfur dioxide allowances, which have an established market value under the 1990 Clean Air Act Amendments, to a non-profit environmental group to be retired. This exchange reduces both acid rain and greenhouse gas emissions.

Nearly all utilities that operate fossil-fuel-fired generators are committed to efficiency improvements. Tampa Electric Company and Sierra Pacific cite their participation in DOE's Clean Coal Technology Program as a way to more efficiently generate electricity and concurrently reduce $\mathrm{CO}_{2}$ emissions by $25 \%$ (compared to a conventional power plant).

American Electric Power (AEP) committed to plant 15 million trees on 20,000 acres of company-owned land. Several species of pine and hardwood are being planted, enhancing the value of these lands as a diverse forest and improving the overall wildlife habitat. Over a 30 -year project period, AEP estimates that carbon sequestration will equal about 1.63 million tons of $\mathrm{CO}_{2}$. AEP is also investigating cofiring of biomass with coal.

A significant effect of the Climate Challenge program is the shift in thinking of electric utility management and strategic planners to include the mitigation of greenhouse gas emissions into their corporate culture and philosophy.

Potential Future Benefits

Utility commitments under Climate Challenge are expected to reduce 47.6 $\mathrm{MMTC}$ of $\mathrm{CO}_{2}$ emissions in the year 2000 .

\section{For More Information}

Climate Challenge web site: http://www.eren.doe.gov/climatechallenge/ 


\section{High Temperature Materials Laboratory}

The government's primary role in research and development is to support long-range, high-risk activities where breakthroughs offer large potential payoffs to the nation. The High Temperature Materials Laboratory (HTML) at Oak Ridge National Laboratory gives researchers from industry, academia, and federal laboratories access to some of the most advanced materials characterization equipment in the world. Sponsored by DOE's Office of Transportation Technologies, HTML and its User Program conduct world-class materials research focused on solving high-temperature and advanced materials problems that limit the efficiency and reliability of advanced energy-conversion systems (diesel engines, for example).

Because the User Program is intended to promote research that will help the United States meet technological challenges from foreign competitors, participants conducting research can use the facilities at no cost, provided the research results are openly published for the benefit of U.S. scientific and industrial communities.

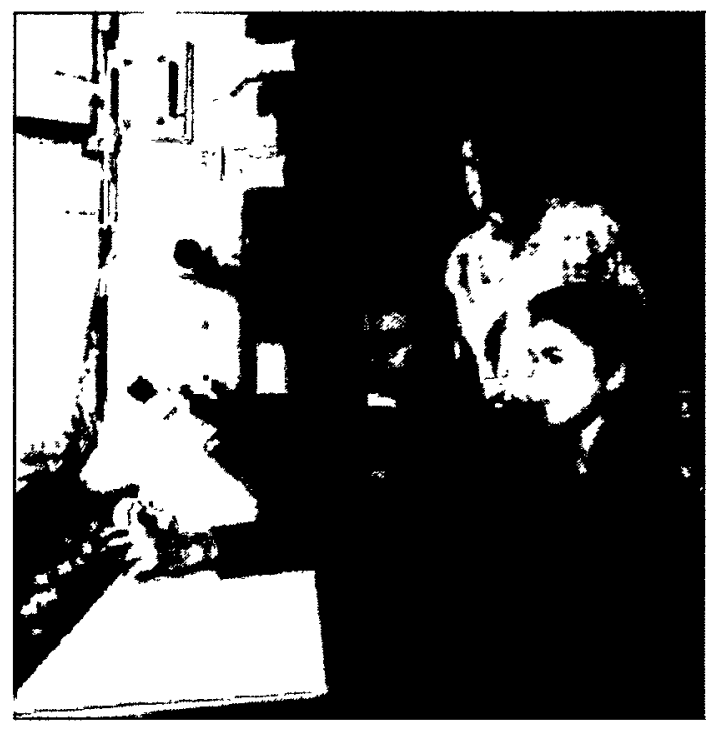

Facility users range from industry giants like Ford Motor Company and Dow Chemical Company to small start-up companies that lack sufficient capital to invest in advanced instrumentation. For example, LoTEC, Inc., a Salt Lake City manufacturer of low-thermal-expansion ceramic components, used the HTML facility in 1992 when it had only seven employees. One of the company's research engineers spent six months at ORNL using a wide range of HTML's capabilities, including dilatometry, electron microscopy, $\mathrm{x}$-ray diffraction, and laser thermal diffusivity. The instrumentation was used to resolve several problems related to formulation and heat treating of low-thermalexpansion ceramic components for engine exhaust manifolds.

Ford Research Laboratory engineers recently used the Thermophysical Properties User Center to evaluate the thermophysical characteristics of new lightweight materials for automobile brakes. Once perfected, such materials will reduce the mass of automotive vehicles and increase their fuel efficiency, which will in turn reduce pollution. Use of HTML's flash thermal diffusivity equipment and differential scanning calorimeter allowed Ford engineers to characterize the properties and performance of these candidate automotive brake materials at room temperature and at high temperatures. The thermophysical property data collected at HTML was used in finite-element and heat-transfer models to evaluate use of an aluminum-metal-matrix composite for brakes. It also allowed Ford engineers to get hands-on experience with advanced equipment before deciding whether to invest in a purchase.

The HTML facility has received an average of about $\$ 5$ million per year in DOE funding in recent years. This funding has enabled HTML's user centers-Materials Analysis, Mechanical Characterization and Analysis, Machining and Inspection Research, Thermophysical Properties, Diffraction, and Residual Stress-to complete more than 800 projects over an eleven-year period. 


\section{APPENDIX A}

\section{DETAILS ON THE EERE SUCCESS METRICS}

The summary analysis is based on 20 accomplishments (11 R\&D successes and nine field verification, deployment, and outreach successes), for which quantified benefits could be measured for products and technologies installed to date. Data on estimated future benefits for emerging technology programs were also collected.

The accomplishments detailed in this compilation were drawn from an array of different sources and describe a variety of program activities. The approach taken and the assumptions made in the calculation of benefits and costs differ across stories. In some cases, an accomplishment describes the benefits and costs accruing from one year of a program's operation. In other cases, the benefits and costs are cumulative for the entire life of the program. In some instances "energy cost savings" include only energy savings that have been realized to date. In other instances, the estimates incorporate the savings that will occur throughout the operating lifetimes of equipment installed to date. There are differences in the use of nominal or real dollars, the assumed discount rate, and so on. These differences are limited somewhat by the EERE Programs' use of common references such as price forecasts and other assumptions in publications such as the Energy Information Administration's Annual Energy Outlook. Because of these differences, we have made no attempt to compare aggregate costs and benefits across the success stories.

As a means of external validation and quality control, the accomplishments and their supporting documentation were reviewed by experts from government, universities and the private sector who are familiar with the technologies and with program evaluation techniques. The assumptions in each success story were reviewed for conformity with accepted evaluation methodologies. However, limited resources did not permit extensive recalculations based on standardized assumptions.

Time horizons for measuring benefits are shown below.

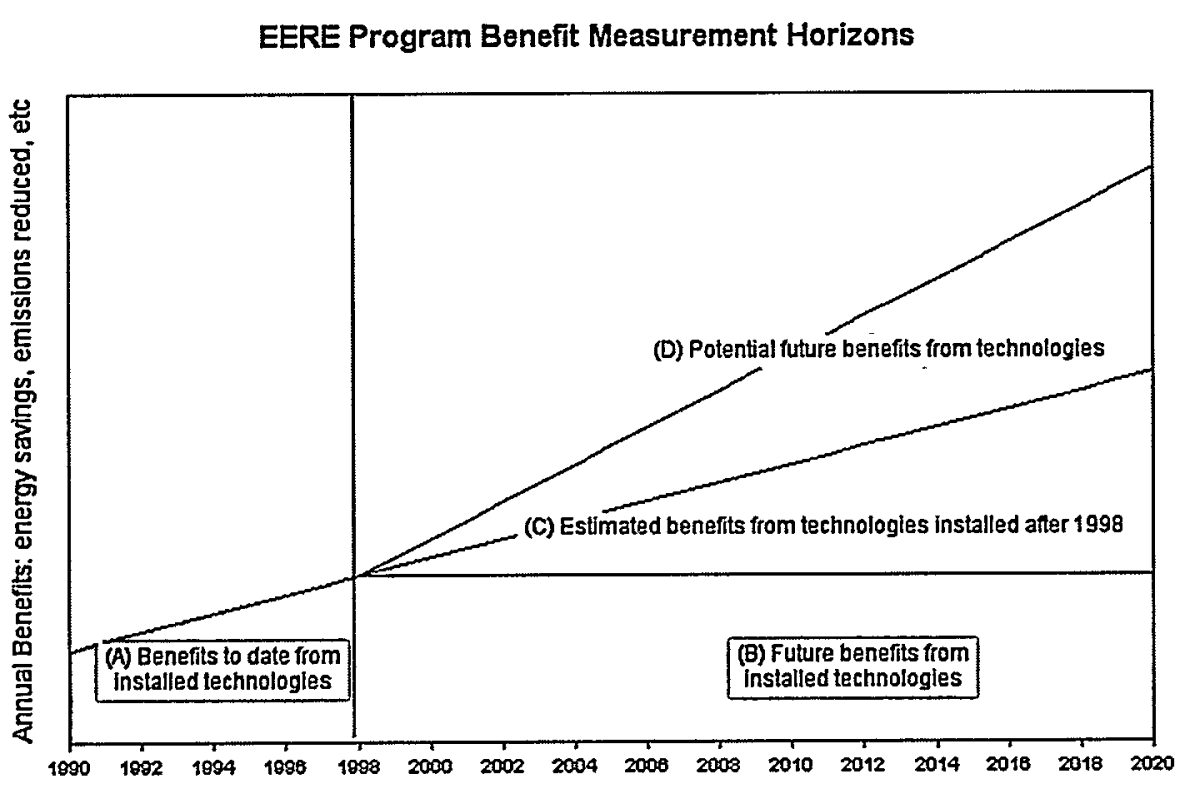


Section A shows the benefits to date from commercialized technologies that were installed prior to 1999. These are annual benefits from EERE technologies currently installed the marketplace. These benefits expand over time as market penetration increases. The time horizon used in this report for describing these benefits typically begins with the year of market introduction and continues through 1998.

Section B shows the future benefits from commercialized technologies that were installed prior to 1999. This is a characterization of future benefits from EERE technologies currently installed and that continue to produce benefits. The time horizon for these benefits is based on the lifetime of the particular technology. That lifetime might be quite short (e.g., the 7-year lifetime of a compact fluorescent torchiere) or quite long (e.g., the 30-year operational life of a new wind turbine).

Section $C$ shows estimated future benefits from technologies installed after 1998. These future benefits come from two sources: (1) the greater market penetration of previously commercialized EERE technologies and (2) emerging technologies that will enter the market in future years. The magnitude of these benefits is tied to the amount of funding projected for EERE programs.

Section D shows the potential future benefits from technologies. This represents what the full market potential could be for EERE technologies if all market imperfections were overcome. The estimate includes the effect of stock turnover and does not assume that the new technologies will accelerate the retirement of operating equipment unless the life-cycle economics are sufficiently compelling.

The level of DOE R\&D investment and the actual benefits from the successes showcased in this report are summarized in Table 1. A finer breakdown of these estimates of costs and benefits is provided in Tables 2, 3, and 4. These metrics represent a combination of cumulative and annual numbers and are based on technologies installed to date.

Table 1. Summary Success Metrics for Recent EERE Accomplishments ${ }^{\mathrm{a}}$

\begin{tabular}{|c|c|c|c|}
\hline Metric & $\begin{array}{c}\text { R\&D } \\
\text { Successes } \\
(\mathrm{N}=\mathbf{1 1}) \\
\end{array}$ & $\begin{array}{c}\text { Field } \\
\text { Verification, } \\
\text { Deployment, } \\
\text { and Outreach } \\
\text { Successes }(N=9)\end{array}$ & Totals \\
\hline DOE R\&D Investment (million \$) & $\$ 230$ & $\$ 480$ & $\$ 710$ \\
\hline Energy Saved (trillion Btu) & 5,050 & 500 & 5,550 \\
\hline Energy Replaced (trillion Btu) & 110 & 1,580 & 1,690 \\
\hline Energy Cost Savings (million $\$$ ) & $--\ldots *$ & $--* *$ & $\ldots * *$ \\
\hline Value of Energy Displaced (million $\$$ ) & $--* *$ & $--* *$ & $--* *$ \\
\hline Carbon Emission Reductions (MMTC) & 89 & 13 & 102 \\
\hline
\end{tabular}

${ }^{a}$ See Tables 2 and 3 for details.

**Because the dollar values that comprise these totals are not standardized to a common base year, totals are not provided. Based on the 5,550 trillion Btu of energy savings and the cost to consumers of an average Btu of energy consumed in 1998, the value of energy saved for all 20 successes is estimated to be $\$ 30$ billion (\$1998). 
Table 2. Metrics for R\&D Successes ${ }^{1}$

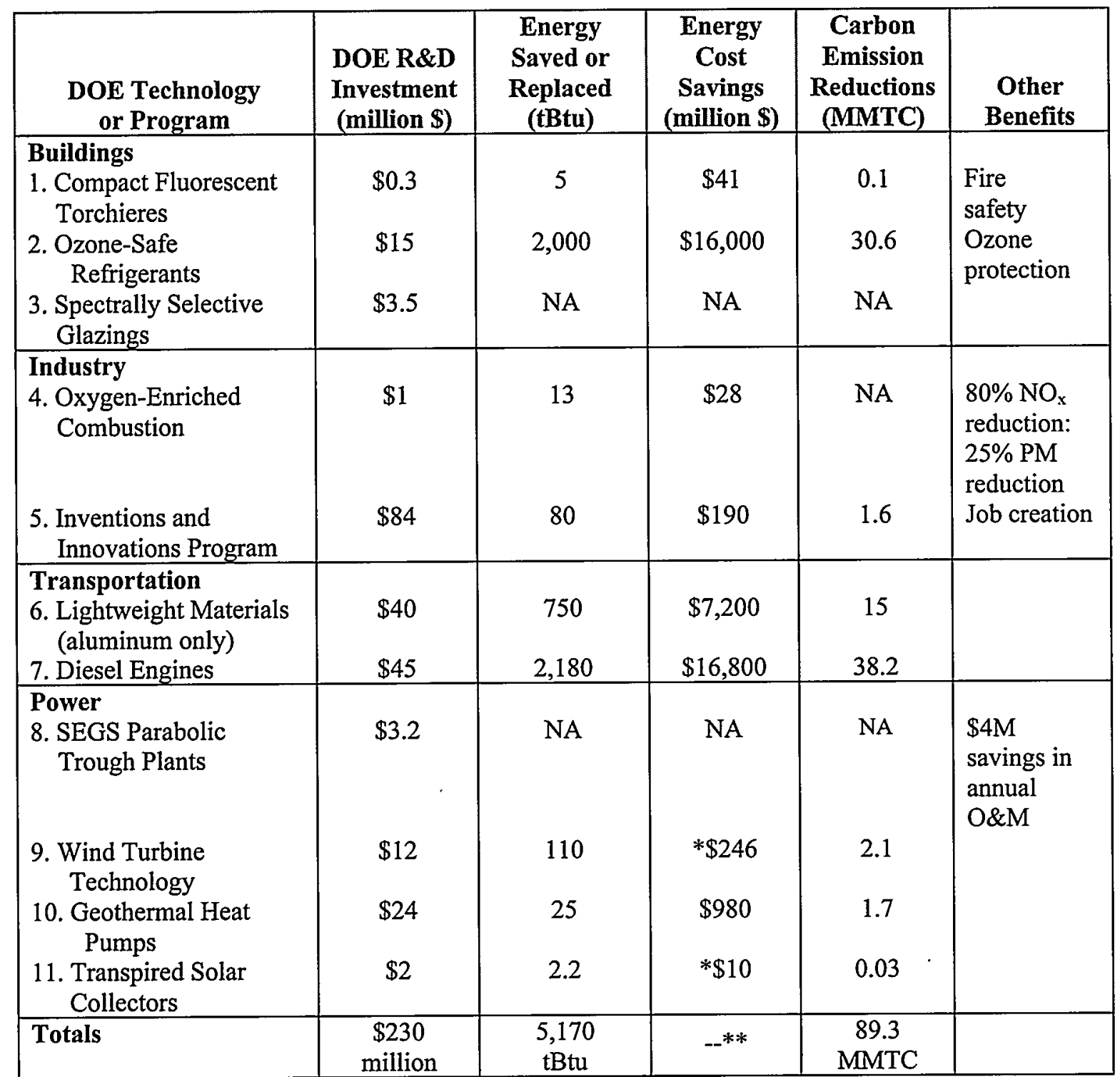

${ }^{1}$ Metrics are a combination of cumulative and annual numbers, and impacts to date over the lifetimes of installed products. See the end notes for an explanation of the metrics for each technology or program. MT = metric tons. MMTC = million metric tons. PM $=$ particulate matter.

* Represents the cost of displaced energy, where oil or other fossil fuels have been displaced by cleaner sources of energy.

**Because the dollar values that comprise these totals are not standardized to a common base year, totals are not provided. 
Table 3. Metrics for Field Verification, Deployment, and Outreach Successes ${ }^{1}$

\begin{tabular}{|c|c|c|c|c|c|}
\hline $\begin{array}{l}\text { DOE Technology or } \\
\text { Program }\end{array}$ & $\begin{array}{l}\text { DOE R\&D } \\
\text { Investment } \\
\text { (million \$) }\end{array}$ & $\begin{array}{l}\text { Energy } \\
\text { Saved or } \\
\text { Replaced } \\
\text { (tBtu) }\end{array}$ & $\begin{array}{c}\text { Energy } \\
\text { Cost } \\
\text { Savings } \\
\text { (million \$) }\end{array}$ & $\begin{array}{l}\text { Carbon } \\
\text { Emission } \\
\text { Reductions } \\
\text { (MMTC) } \\
\end{array}$ & $\begin{array}{l}\text { Other } \\
\text { Benefits }\end{array}$ \\
\hline Buildings & & & & & \\
\hline $\begin{array}{l}\text { 12. Weatherization } \\
\text { Program }\end{array}$ & $\$ 125$ & 108 & $\$ 550$ & 1.63 & $\begin{array}{l}\text { Health, } \\
\text { safety }\end{array}$ \\
\hline $\begin{array}{l}\text { 13. Promoting Buildings } \\
\text { Standards }\end{array}$ & $\$ 144$ & 154 & $\$ 1,120$ & 3.55 & \\
\hline 14. Rebuild America & $\$ 7$ & 32 & $\$ 162$ & 0.40 & New jobs \\
\hline $\begin{array}{l}\text { Federal Energy } \\
\text { Management } \\
\text { 15. Energy Savings } \\
\text { Performance } \\
\text { Contracts } \\
\end{array}$ & $\$ 8$ & NA & NA & NA & NA \\
\hline $\begin{array}{l}\text { Industry } \\
\text { 16. Energy Technologies } \\
\text { at Bethlehem Steel }\end{array}$ & NA & 2 & $\$ 8$ & 0.01 & $\begin{array}{l}171 \mathrm{MT} \\
\mathrm{NO}_{\mathrm{x}} \\
395 \mathrm{MT} \\
\mathrm{SO}_{\mathrm{x}} \\
2 \mathrm{MT} \\
\text { VOCs }\end{array}$ \\
\hline $\begin{array}{l}\text { 17. Industrial Assessment } \\
\text { Centers }\end{array}$ & $\$ 47$ & 71 & $\$ 300$ & 1.51 & . \\
\hline 18. Motor Challenge & $\$ 6$ & 131 & $\$ 2$ & 0.01 & $\begin{array}{l}18 \mathrm{MT} \mathrm{NO}_{\mathrm{x}} \\
16 \mathrm{MT} \mathrm{SO}_{\mathrm{x}}\end{array}$ \\
\hline $\begin{array}{l}\text { Transportation } \\
\text { 19. Alternative Vehicles } \\
\text { in Clean Cities }\end{array}$ & $\$ 15$ & 48 & $* \$ 900$ & 0.40 & \\
\hline $\begin{array}{l}\text { 20. Ethanol Fuels } \\
\text { Program } \\
\end{array}$ & $\$ 130$ & 1,530 & $* \$ 12,000$ & 5.00 & \\
\hline Totals & $\begin{array}{l}\$ 482 \\
\text { million }\end{array}$ & $\begin{array}{c}2,080 \\
\text { tBtu }\end{array}$ & -_** & $\begin{array}{c}12.5 \\
\text { MMTC }\end{array}$ & \\
\hline
\end{tabular}

${ }^{1}$ Metrics are a combination of cumulative and annual numbers, and impacts to date over the lifetimes of installed products. See the end notes for an explanation of the metrics for each technology or program. MT = metric tons. MMTC $=$ million metric tons. $\mathrm{PM}=$ particulate matter.

*Represents the cost of displaced energy, where oil or other fossil fuels have been displaced by cleaner sources of energy.

**Because the dollar values that comprise these totals are not standardized to a common base year, totals are not provided. 
Table 4. Metrics for Emerging R\&D Successes ${ }^{1}$

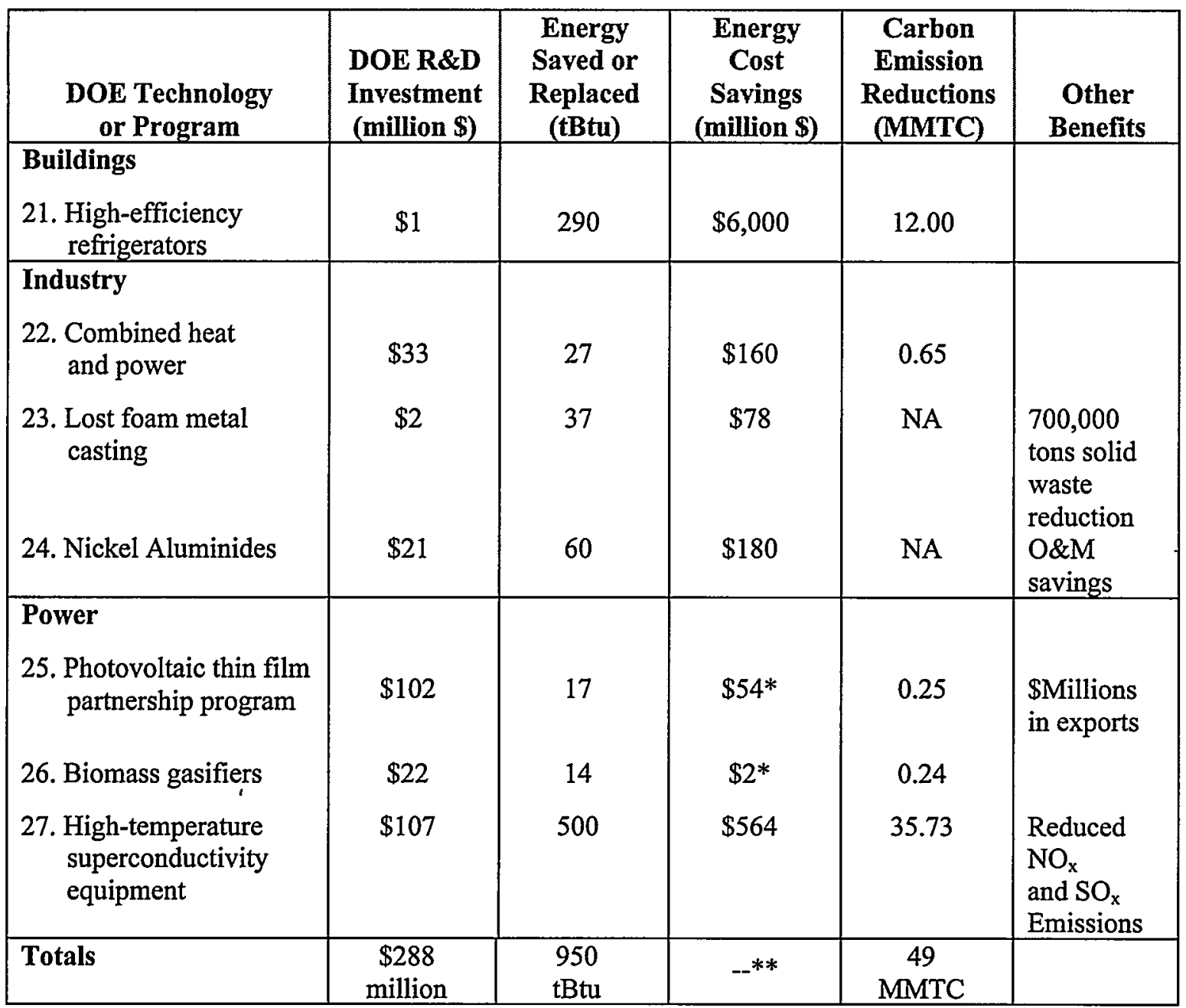

${ }^{1}$ Metrics are a combination of cumulative and annual numbers, and impacts to date over the lifetimes of installed products. See the end notes for an explanation of the metrics for each technology or program. MT = metric tons. MMTC = million metric tons. $\mathrm{PM}=$ particulate matter.

*Represents the cost of displaced energy, where oil or other fossil fuels have been displaced by cleaner sources of energy.

**Because the dollar values that comprise these totals are not standardized to a common base year, totals are not provided. 


\section{NOTES FROM TABLES 2, 3 AND 4}

\section{R\&D Successes}

1. [Compact Fluorescent Torchieres] These metrics indicate the energy displacement, cost savings, and emission reductions that may be realized over the fluorescent bulb's expected 7-year lifetime. The benefits in 1998 are: 0.75 tBtu displaced, $\$ 4.8$ million saved, and 0.01 MMTC reduced.

2. [Ozone-Safe Refrigerants] Figures shown represent cumulative energy displacement, energy cost savings, and carbon emission reductions for the period 1994-96. DOE R\&D investment figure is cumulative from 1985 to 1998.

3. [Spectrally Selective Glazings] These metrics are not yet available. DOE R\&D investment shown is cumulative from 1986 to 1996.

4. [Oxygen-Enriched Combusion] Energy displacement and energy cost savings are shown cumulatively from 1991 to 1997 . The benefits in 1997 are: $3.4 \mathrm{tBtu}$ displaced and $\$ 7.2$ million saved. DOE R\&D investment figure represents cost share of initial demonstration.

5. [Inventions \& Innovations Program] Figures shown are DOE investment, energy displacements, energy cost savings, and carbon emission reductions from I\&I program developments through the year 1996.

6. [Lightweight Materials] Figures show cumulative benefits through 1997 and are based upon weight reductions beginning in 1978. Dollar savings are "current dollars."

7. [Diesel Engines] Figures show cumulative benefits from 1983 to 1997. Dollar savings are "current dollars."

8. [SEGS Parabolic Trough Plants] Several of these metrics are not available. DOE R\&D investment period is1992-1997.

9. [Wind Turbine Technology] Energy displacement, energy cost savings, and carbon emission reduction figures indicate energy displacement, savings, and emission reductions over the turbine's lifetimes. The benefits to date are: $1.3 \mathrm{tBtu}$ displaced, $\$ 2.5$ million displaced, and 0.024 MMTC reduced.

10. [Geothermal Heat Pumps] Energy displacement, energy cost savings, and carbon emission reduction figures indicate the potential energy displacement, savings, and emission reductions possible over the lifetimes of heat pumps installed from 1995 through 1998. DOE \&RD investment shown is for years 1995 through 1998. Benefits to date for the same period are: 4.3 trillion Btus displaced, \$34 million saved, 0.1 MMTC reduced.

11. [Transpired Solar Collectors] Energy displacement, energy cost savings, and carbon emission reduction figures indicate energy displacement, savings, and emission reductions possible over the lifetime of the collectors. The benefits to date are: $0.3 \mathrm{tBtu}$ displaced, $\$ 1.2$ million displaced, and 0.004 MMTC reduced.

\section{Field Verification, Deployment, and Outreach Successes}

12. [Weatherization Program] DOE investment shown is for 1998 only. The program also leveraged an additional $\$ 198$ million in funding. Energy savings are for the 20 -year lifespan of the weatherization measures installed through $1996.8,000$ jobs were created.

13. [Promoting Buildings Standards] DOE investment shown is cumulative from 1980 to 1998 . Energy displacement, cost savings, and carbon emission reduction data are for 1998.

14. [Rebuild America] DOE investment shown is over the period 1995 to 1998. Annual energy cost savings and annual carbon emission reductions are for 1999.

15. [Energy Savings Performance Contracts] DOE investment figure includes all ESPC and utility financing for 1999. Energy savings shown are cumulative for all projects over a 25 year period if the maximum value of contract authority in place by 2000 is used. Annual carbon emission reductions are estimated at the point in time when all ESPCs are in place. 
16. [Energy Technologies at Bethlehem Steel] Energy displacement, cost savings, emission reduction, and other benefits figures realized on an annual basis at Burns Harbor from installation/operation of energy efficient equipment.

17. [Industrial Assessment Centers] Investment figure calculated over the period 1976 - present. Energy displacement, energy cost savings, and carbon emission reductions are annual savings and reductions to be realized by year 2000 .

18. [Motor Challenge] DOE investment in FY1998 for entire Motor Challenge program. Energy displacement and cost savings are for a single year from 13 Motor Challenge Showcases. If replicated industry-wide, cost savings will be $\$ 370$ million by 2010 .

19. [Alternative Vehicles in Clean Cities] Figures show cumulative benefits from 1993 to 1998. Dollar savings are "current dollars."

20. [Ethanol Fuels Program] Figures show cumulative benefits through 1998 and are based upon the use of ethanol blends in gasoline beginning in 1982. Dollar savings are "current dollars."

\section{Emerging Technologies}

21. [High-efficiency refrigerators] Previous DOE investment saved $\$ 6$ billion (in 1980 to 1990). This success story describes R\&D accomplishments that could save an additional $\$ 6$ billion per year. The DOE R\&D investment is cumulative from 1991 through 1997.

22. [Combined heat and power] Investment is shown for FY1999. Annual energy savings, energy cost savings, $\mathrm{CO} 2$ emission reductions are calculated to be in effect by the year 2000 .

23. [Lost foam metal casting] Investment from 1992 to 1997. Annual energy savings and energy cost savings occur if a $30 \%$ reduction in energy requirements of melting is achieved. There will also be a 700,000 ton reduction of solid waste.

24. [Nickel Aluminides] Energy displacement and cost savings as projected to be achieved by 2015 . Investment is over the period 1982 to 1998 from DOE Offices of Science, Fossil Energy, and Energy Efficiency. There have been \$3 million in sales of nickel aluminides through 1998.

25. [Photovoltaic thin film partnership program] DOE R\&D investment is cumulative from 1994 to 1999. Energy savings, energy cost savings, and CO2 emission reductions are projections for the year 2020.

26. [Biomass gasifiers] DOE investment has been since 1994. Energy savings, energy cost savings and $\mathrm{CO} 2$ emission reductions are projections for the year 2010.

27. [High-temperature superconductivity equipment] Investment from 1996 to 1999. Energy cost savings are for the year 2010 . 


\section{APPENDIX B \\ ACRONYMS AND GLOSSARY}

\section{ACRONYMS}

$\begin{array}{ll}\text { AEO } & \text { Annual Energy Outlook } \\ \text { AER } & \text { Annual Energy Review } \\ \text { AFV } & \text { Alternative-fueled vehicle } \\ \text { ANL } & \text { Argonne National Laboratory } \\ \text { ASHRAE } & \text { American Society of Heating, Refrigeration, and Air-conditioning Engineers } \\ \text { BTS } & \text { Office of Building Technology, State and Community Programs } \\ \text { Btu } & \text { British Thermal Unit } \\ \text { CAFE } & \text { Corporate Average Fuel Economy standard } \\ \text { C } & \text { Carbon } \\ \text { CC } & \text { Combined Cycle } \\ \text { CO } & \text { Carbon Dioxide } \\ \text { CRADA } & \text { Cooperative Research and Development Agreement } \\ \text { CT } & \text { Combustion Turbine } \\ \text { DOE } & \text { U.S. Department of Energy } \\ \text { EERE } & \text { Office of Energy Efficiency and Renewable Energy } \\ \text { EIA } & \text { Energy Information Administration } \\ \text { EPA } & \text { U.S. Environmental Protection Agency } \\ \text { EPACT } & \text { Energy Policy Act of 1992 } \\ \text { ESPC } & \text { Energy Savings Performance Contract } \\ \text { FEMP } & \text { Federal Energy Management Program } \\ \text { FY } & \text { Fiscal Year } \\ \text { GDI } & \text { Gasoline direct injection } \\ \text { GDP } & \text { Gross Domestic Product } \\ \text { GW } & \text { GigaWatt } \\ \text { HVAC } & \text { Heating, Ventilation, and Air-Conditioning } \\ \text { IGCC } & \text { Integrated Gasification Combined Cycle } \\ \text { kWh } & \text { kiloWatt-hour } \\ \text { LBNL } & \text { Lawrence Berkeley National Laboratory } \\ \text { LDV } & \text { Light-duty vehicle } \\ \text { MBtu } & \text { Million Btu } \\ \text { mmbd } & \text { million barrels of oil per day } \\ \text { MMTC } & \text { Million metric tons of carbon } \\ \text { MW } & \text { Megawatt } \\ \text { NAECA } & \text { National Appliance Energy Conservation Act of 1987 } \\ \text { NEMS } & \text { National Energy Modeling System } \\ \text { NREL } & \text { National Renewable Energy Laboratory } \\ \text { OIT } & \text { Office of Industrial Technologies } \\ \text { OPT } & \text { Office of Power Technologies } \\ \text { ORNL } & \text { Oak Ridge National Laboratory } \\ \text { OTT } & \text { Office of Transportation Technologies } \\ \text { PATH } & \text { Partnership for Advanced Technology in Housing } \\ \text { PM } & \text { Particulate matter } \\ \text { PNGV } & \text { Partnership for a New Generation of Vehicles } \\ \text { PNNL } & \text { Pacific Northwest National Laboratory } \\ & \end{array}$




$\begin{array}{ll}\text { PV } & \text { Photovoltaics } \\ \text { R\&D } & \text { Research and Development } \\ \text { RD\&D } & \text { Research, Development and Demonstration } \\ \text { SEAB } & \text { Secretary's Energy Advisory Board } \\ \text { SNL } & \text { Sandia National Laboratories } \\ \text { tBtu } & \text { Trillion Btu } \\ \text { TWh } & \text { TeraWatt-hour } \\ \text { VMT } & \text { Vehicle miles traveled } \\ \text { VOC } & \text { Volatile organic compounds }\end{array}$

\section{GLOSSARY}

Barrel (petroleum): A unit of volume equal to 42 U.S. gallons.

Biomass: Any organic matter available on a renewable or a recurrent basis, including agricultural crops and residues, wood and wood residues, urban and animal residues, and aquatic plants.

Bioenergy: Energy derived from biomass as electricity or heat, or combinations of heat and power; in the form of liquid or gaseous fuels, it is often referred to as biofuels.

British thermal unit (Btu): One British thermal unit, or Btu, is roughly equivalent to burning one kitchen match. It is the quantity of heat required to raise the temperature of one pound of water one degree Fahrenheit. (one Btu $=1055$ Joules)

Carbon dioxide $\left(\mathrm{CO}_{2}\right)$ : A colorless, odorless, non-poisonous gas that is a normal part of the ambient air. Carbon dioxide is a product of fossil fuel combustion.

Climate change: The change in weather patterns and surface temperatures that appears to be occurring as the result of large increases in greenhouse gas concentrations in the earth's atmosphere.

Cogeneration: The production of electrical energy and another form of useful energy (such as heat or steam) through the sequential use of energy.

Combined Cycle: An electric generating technology in which electricity is produced from otherwise lost waste heat exiting from one or more gas (combustion) turbines. The exiting heat is routed to a conventional boiler or to a heat recovery steam generator for utilization by a steam turbine in the production of electricity. Such designs increase the efficiency of the electric generating unit.

Criteria Pollutant: A pollutant determined to be hazardous to human health and regulated under the Environmental Protections Agency's (EPA) National Ambient Air Quality Standards. The 1970 amendments to the Clean Air Act require EPA to describe the health and welfare impacts of a pollutant as the "criteria" for inclusion in thè regulatory regime.

Crude oil: A mixture of hydrocarbons that exists in the liquid phase in natural underground reservoirs and remains liquid at atmospheric pressure after passing through surface separating facilities. Crude oil production is measured at the wellhead and includes lease condensate.

Discount Rate: The interest rate used to assess the value of future cost and revenue streams; an essential factor in assessing true returns from an investment in energy efficiency, as well as opportunity costs associated with not making that investment. Real discount rates do not include inflation. To obtain the 
equivalent nominal discount rate including inflation, simply add the percentage annual inflation rate to the real discount rate

Distillate fuel oil: The lighter fuel oils distilled off during the refining process. Included are products known as ASTM grades numbers 1 and 2 heating oils, diesel fuels, and number 4 fuel oil. The major uses of distillate fuel oils include heating, fuel for on- and off-highway diesel engines, and railroad diesel fuel.

Electric Utility Restructuring: With some notable exceptions, the electric power industry historically has been composed primarily of investor-owned utilities. These utilities have been predominantly vertically integrated monopolies (combining electricity generation, transmission, and distribution), whose prices have been regulated by State and Federal government agencies. Restructuring the industry entails the introduction of competition into at least the generation phase of electricity production, with a corresponding decrease in regulatory control. Restructuring may also modify or eliminate other traditional aspects of investor-owned utilities, including their exclusive franchise to serve a given geographical area, assured rates of return, and vertical integration of the production process.

Energy: The capacity for doing work as measured by the capability of doing work (potential energy) or the conversion of this capability to motion (kinetic energy). Energy has several forms, some of which are easily convertible and can be changed to another form useful for work. Most of the world's convertible energy comes from fossil fuels that are burned to produce heat that is then used as a transfer medium to mechanical or other means in order to accomplish tasks. Electrical energy is usually measured in kilowatthours, while heat energy is usually measured in British thermal units.

Energy Service Company (ESCo): A company which designs, procures, finances, installs, maintains, and guarantees the performance of energy conservation measures in an owner's facility or facilities.

Energy Saving Performance Contract (ESPC): An agreement with a third party in which the overall performance of installed energy conservation measures is guaranteed by that party.

Ethanol: A denatured alcohol $\left(\mathrm{C}_{2} \mathrm{H}_{5} \mathrm{OH}\right)$ intended for motor gasoline blending.

Externalities: Benefits or costs, generated as a byproduct of an economic activity, that do not accrue to the parties involved in the activity.

Fluorescent Lamps: Fluorescent lamps produce light by passing electricity through a gas, causing it to glow. The gas produces ultraviolet light; a phosphor coating on the inside of the lamp absorbs the ultraviolet light and produces visible light. Fluorescent lamps produce much less heat than incandescent lamps and are more energy efficient.

Fossil Fuel: Any naturally occurring organic fuel formed in the Earth's crust, such as petroleum, coal, and natural gas.

Fuel Cells: One or more cells capable of generating an electrical current by converting the chemical energy of a fuel directly into electrical energy. Fuel cells differ from conventional electrical cells in that the active materials such as fuel and oxygen are not contained within the cell but are supplied from outside.

Gas-Turbine Electric Power Plant: A plant in which the prime mover is a gas turbine. A gas turbine typically consists of an axial-flow air compressor and one or more combustion chambers in which liquid or gaseous fuel is burned. The hot gases expand to drive the generator and then are used to run the compressor. 
Global Warming: Global warming is the increase in global temperatures that the earth has been experiencing this century. Gases that are thought by many to contribute to global warming through the greenhouse effect include carbon dioxide, methane, nitrous oxides, chlorofluorocarbons (CFCs), and halocarbons (the replacements for CFCs). Carbon dioxide emissions are primarily caused by the use of fossil fuels for energy.

Greenhouse Gas: Any gas that absorbs infrared radiation in the atmosphere.

Heat Pump: A device that extracts available heat from one area (the heat source) and transfers it to another (the heat sink) to either heat or cool an interior space. Geothermal heat pumps can operate more efficiently than the standard air-source heat pumps, because during winter the ground does not get as cold as the outside air (and during the summer, it doe not heat up as much).

Independent Power Producer (IPP): A wholesale electricity producer (other than a qualifying facility under the Public Utility Regulatory Policies Act of 1978), that is unaffiliated with franchised utilities. Unlike traditional utilities, IPPs do not possess transmission facilities that are essential to their customers and do not sell power in any retail service territory where they have a franchise.

Kerosene: A petroleum distillate that is used in space heaters, cook stoves, and water heaters; it is suitable for use as an illuminant when burned in wick lamps (see Watthour).

Kilowatt (kW): One thousand watts of electricity (see Watt).

Kilowatthour (kWh): One thousand watthours.

Light Truck: Two-axle, four-tire trucks with a gross vehicle weight less than 10,000 pounds.

Liquefied Natural Gas (LNG): Natural gas (primarily methane) that has been liquefied by reducing its temperature to $-260^{\circ} \mathrm{F}$ at atmospheric pressure.

Liquefied Petroleum Gas (LPG): Ethane, ethylene, propane, propylene, normal butane, butylene, and isobutane produced at refineries or natural gas processing plants.

Low Emissivity (low-e) Coatings: Emissivity is a measure of how much heat is emitted from an object by radiation. Low-e coatings are put on window panes to reduce the amount of heat they give off through radiation.

Megawatt (MW): One million watts of electricity (see Watt).

Methanol: A light volatile alcohol $\left(\mathrm{CH}_{3} \mathrm{OH}\right)$ used for motor gasoline blending.

Natural Gas: A mixture of hydrocarbons (principally methane) and small quantities of various nonhydrocarbons existing in the gaseous phase or in solution with crude oil in underground reservoirs.

Nitrogen Oxides $\left(\mathrm{NO}_{\mathbf{x}}\right)$ : A product of combustion of fossil fuels whose production increases with the temperature of the process. It can become an air pollutant if concentrations are excessive.

Nuclear Electric Power: Electricity generated by an electric power plant whose turbines are driven by steam generated in a reactor by heat from the fissioning of nuclear fuel. 
Oxygenates: Any substance which, when added to motor gasoline, increases the amount of oxygen in that motor gasoline blend.

Ozone: Three-atom oxygen compound $\left(\mathrm{O}_{3}\right)$ found in two layers of the Earth's atmosphere. One layer of beneficial ozone occurs at 7 to 18 miles above the surface and shields the Earth from ultraviolet light. Several holes in this protective layer have been documented by scientists. Ozone also concentrates at the surface as a result of reactions between byproducts of fossil fuel combustion and sunlight, having harmful health effects.

Parabolic Trough: A high-temperature (above 180 degrees Fahrenheit) solar thermal concentrator which focuses direct-beam solar radiation on a linear receiver along its focal line.

Particulates: Visible air pollutants consisting of particles appearing in smoke or mist.

Petroleum: A generic term applied to oil and oil products in all forms.

Photovoltaic Cell: An electronic device consisting of layers of semiconductor materials fabricated to convert incident light directly into electricity (direct current).

Photovoltaic Module: An integrated assembly of interconnected photovoltaic cells designed to deliver a selected level of working voltage and suited for incorporation in photovoltaic power systems.

Primary Energy: The energy that is embodied in resources as they exist in nature (e.g., coal, crude oil, natural gas, or sunlight). For the most part, primary energy is transformed into electricity or fuels such as gasoline or charcoal. These, in turn, are referred to as secondary or site energy.

Propane: A normally gaseous straight-chain hydrocarbon $\left(\mathrm{C}_{3} \mathrm{H}_{8}\right)$. It is a colorless paraffinic gas that is extracted from natural gas or refinery gas streams.

Quadrillion Btu (Quad): Equivalent to 10 to the $15^{\text {th }}$ power Btu (1 quad $=1.055 \times 10 \mathrm{e} 18$ joules).

Renewable Energy: Energy obtained from sources that are essentially inexhaustible (unlike, for example, the fossil fuels, of which there is a finite supply). Renewable sources of energy include conventional hydroelectric power, wood, waste, geothermal, wind, photovoltaic, and solar thermal energy.

Standard Industrial Classification (SIC): A set of codes developed by the Office of Management and Budget which categorizes industries according to groups with similar economic activities.

Turbine: A machine for generating rotary mechanical power from the energy of a stream of fluid (such as water, steam, or hot gas). Turbines convert the kinetic energy of fluids to mechanical energy through the principles of impulse and reaction, or a mixture of the two.

Watt (Electric): The electrical unit of power. The rate of energy transfer equivalent to one ampere of electric current flowing under a pressure of one volt at unity power factor.

Watthour (Wh): The electrical energy unit of measure equal to 1 watt of power supplied to, or taken from, an electric circuit steadily for one hour.

Wind Energy: The kinetic energy of wind converted into mechanical energy by wind turbines (i.e., blades rotating from a hub) that drive generators to produce electricity. 